\title{
13. CALCAREOUS NANNOFOSSILS FROM THE SOUTHERN SOUTHWEST PACIFIC, DEEP SEA DRILLING PROJECT, LEG 29
}

\author{
Anthony R. Edwards, New Zealand Geological Survey, Lower Hutt, New Zealand \\ and \\ Katharina Perch-Nielsen, Institute for Historical Geology and Palaeontology, \\ Østervoldgade 10, 1350 Copenhagen K, Denmark ${ }^{1}$
}

\begin{abstract}
Calcareous nannofossils were obtained from all sites drilled in the southern southwest Pacific on Leg 29 (Figure 1). They occur in mid Paleocene to late Pleistocene sediments and show highly variable states of preservation. Diversity is generally low, as might be expected from the high southern latitudes of the sites drilled. Consequently the biostratigraphic resolution is much lower than that in subtropical and tropical areas, especially the mid Oligocene to early Pliocene part of the column. Great similarity was found between the high southern and high northern latitude assemblages of the same age, although a number of species seem to occur only in the north whereas only very few seem to be restricted to the south. Observations on the fine structure of coccoliths and nannoliths, and comparison with their northern high latitude equivalents, showed a surprisingly high degree of morphological agreement. Three new species, Ericsonia tasmaniae, Helicopontosphaera? subantarctica, and Hornibrookina australis are described.
\end{abstract}

\section{INTRODUCTION}

The calcareous nannofossils (coccoliths and nannoliths) of DSDP Leg 29 were studied from several points of view for this report:

1) Age determinations were deduced from the biostratigraphic studies and the results of these studies are summarized in the appropriate site report chapter.

2) Species distribution of most species observed (using the light microscope) is listed in tables with an outline of the biostratigraphic framework employed in this high latitude region (Tables 1-12).

3) Some paleoecological observations have been made.

4) Nannofossil structure is discussed emphasizing the fine structure of some of the nannofossils in order to compare them with the structure of the same species in the equivalent northern hemisphere environment (Plates 1-21).

\section{Calcareous Nannofossil Biostratigraphy}

The low-diversity nannofloras found in the Neogene and Oligocene do not allow a high-resolution biostratigraphy to be used in this subantarctic region. However, somewhat more diverse assemblages do occur in parts of the Eocene and Paleocene. The biostratigraphic events used for age assignment on Leg 29 are summarized in

\footnotetext{
'Present address: Department of Geology, Swiss Federal Institute of Technology, Zurich, Switzerland.
}

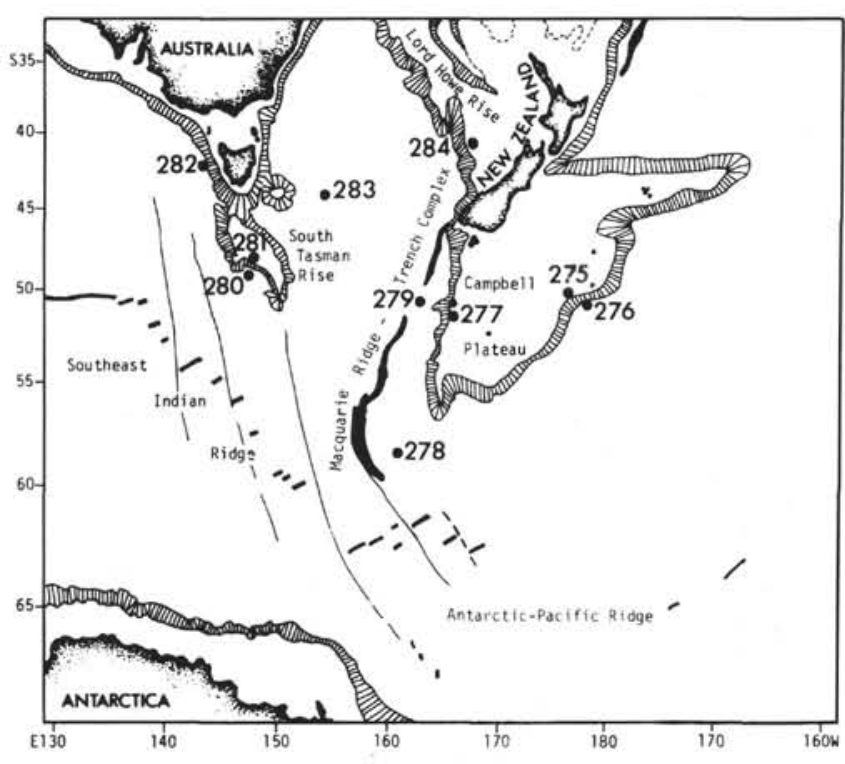

Figure 1. DSDP Leg 29 site locations.

Table 1. Table 2 includes the definition of the calcareous nannofossil biostratigraphic units used on Leg 29 , their correlation with New Zealand stages, and their adopted age. The age distribution of the cores and sections, according to their coccolith and nannolith content, is summarized in Table 3 . In Tables 4 to 12 , the species distribution in all samples studied is given.

Species identification in many samples was often difficult due to heavy overgrowth on the coccoliths and nannoliths. Also the authors each having their own 
TABLE 1

Biostratigraphic Events Used for Age Assignment in DSDP Leg 29 Sites $^{2}$



Note: $B=$ first occurrence of a species; $\mathrm{T}=$ last occurrence.


sites. Late Cenozonic radiometric ages based on paleomagnetic dating of New Zealand marine sediments (Kennett et al., 1972; Kennett and Watkins, 1972). Older ages according to Berggren (1972).

"tradition" and opinion about species names and generic assignments often had to adopt a mutual compromise on the names to be used in this report. Selected species are illustrated on Plates 1-21.

\section{PALEOECOLOGY}

Several paleoenvironmental factors can be reconstructed with reasonable confidence if wellpreserved nannofloras from samples dated by at least one other fossil group are available. In the material examined here, coccoliths older than late Pleistocene are usually only moderately or poorly preserved. Furthermore, coccoliths were often the main basis for determining the age. Thus conditions for paleoecological studies were far from ideal.

The factors influencing a coccolith assemblage from its living state to the sample which is studied are numerous and include:

1) Solution during sinking. This is documented by the fact that only about one third of the living species are found in Recent sediments. Solution at this stage evidently affects different species differently.

2) Sorting of the assemblage according to size by currents (winnowing), both during sinking and in the young sediment.

3) Solution of some species and overgrowth on others as a result of diagenesis. Solution removes part of the assemblage, while overgrowth renders another part nearly or wholly indeterminable. Generally small species are dissolved so the resulting assemblage might be taken for a residual assemblage after winnowing, if the state of preservation of the remaining assemblage is not taken into consideration. Diagenesis, however, affects coccoliths differently at comparable depths (i.e., in a 9-m core) depending on the lithology of the sample (i.e., the presence of clay, zeolites, siliceous organisms, and organic material). Thus, in interbedded lithologies, the presence of different coccolith assemblages or differences in diversity need not indicate major differences in climate, but might result from different 
TABLE 2

Calcareous Nannofossil Biostratigraphic Events and Zones, DSDP Leg 29

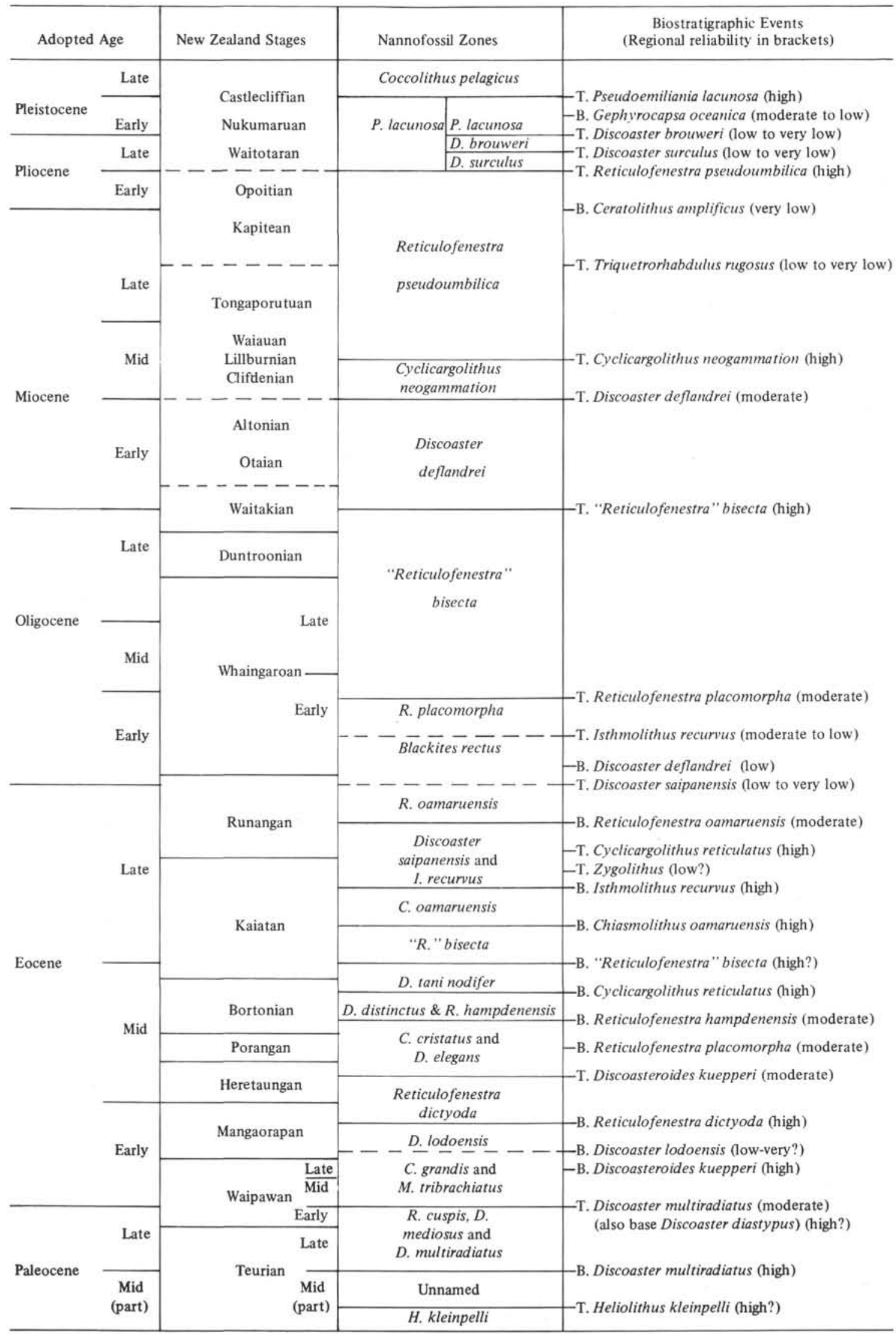

Note: $\mathrm{B}=$ first occurrence of a species; $\mathrm{T}=$ last occurrence. 
TABLE 3

Calcareous Nannofossil Correlations DSDP Leg 29

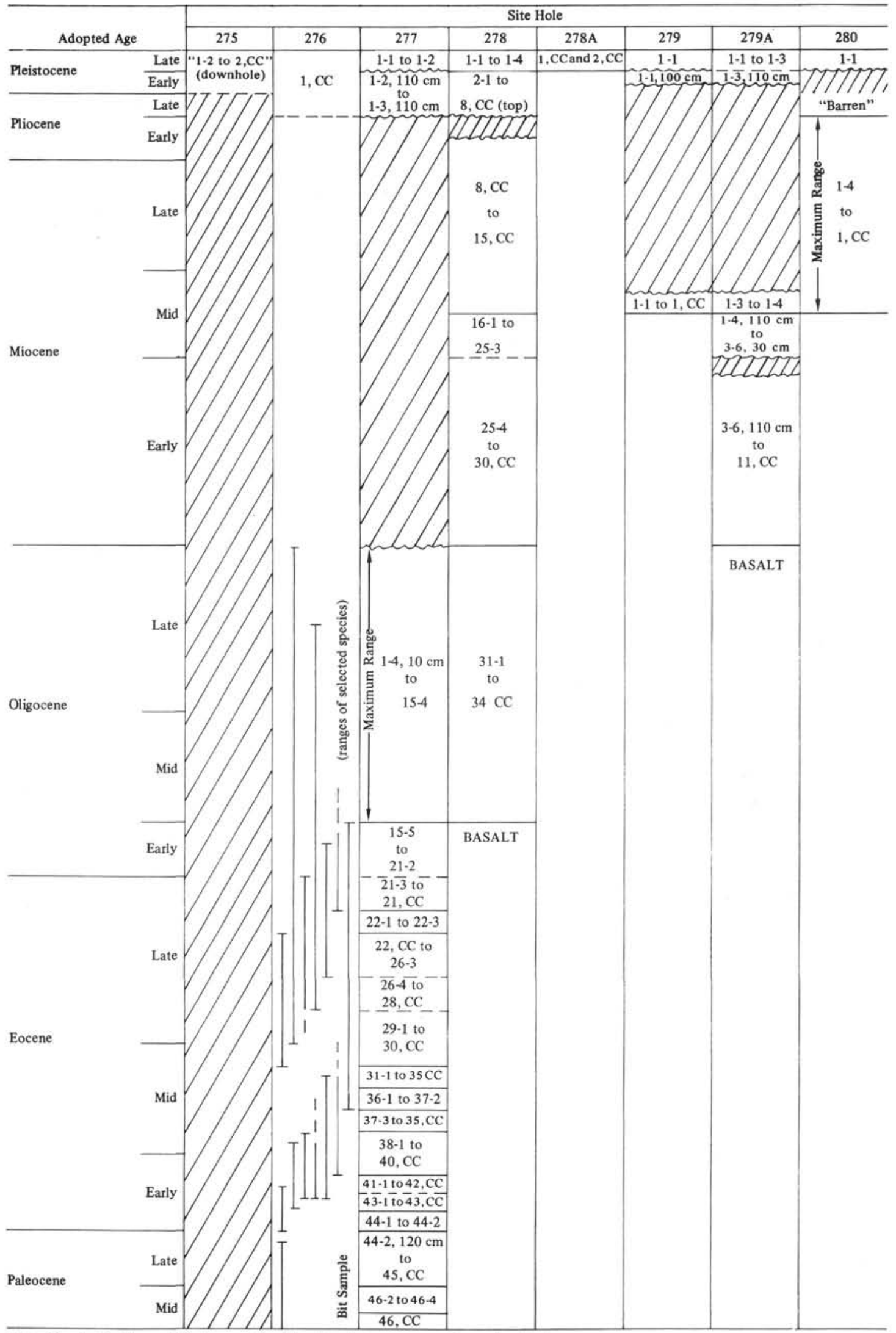

Note: Crosshatched areas indicate unconformities. $\mathrm{B}=$ first occurrence of a species; $\mathrm{T}=$ last occurrence. 
TABLE 3 - Continued

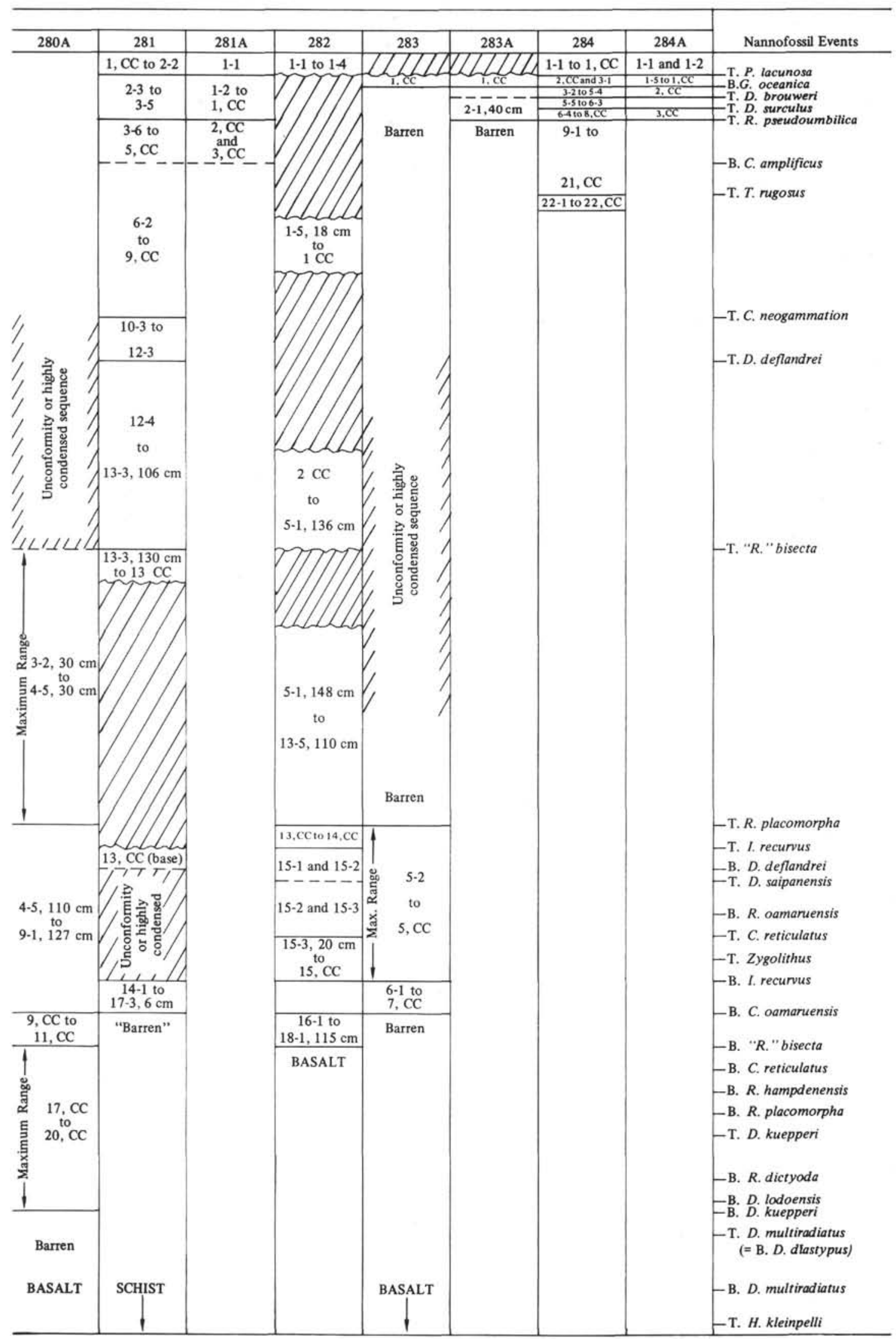


TABLE 4A

Calcareous Nannofossil Distribution, Site 277

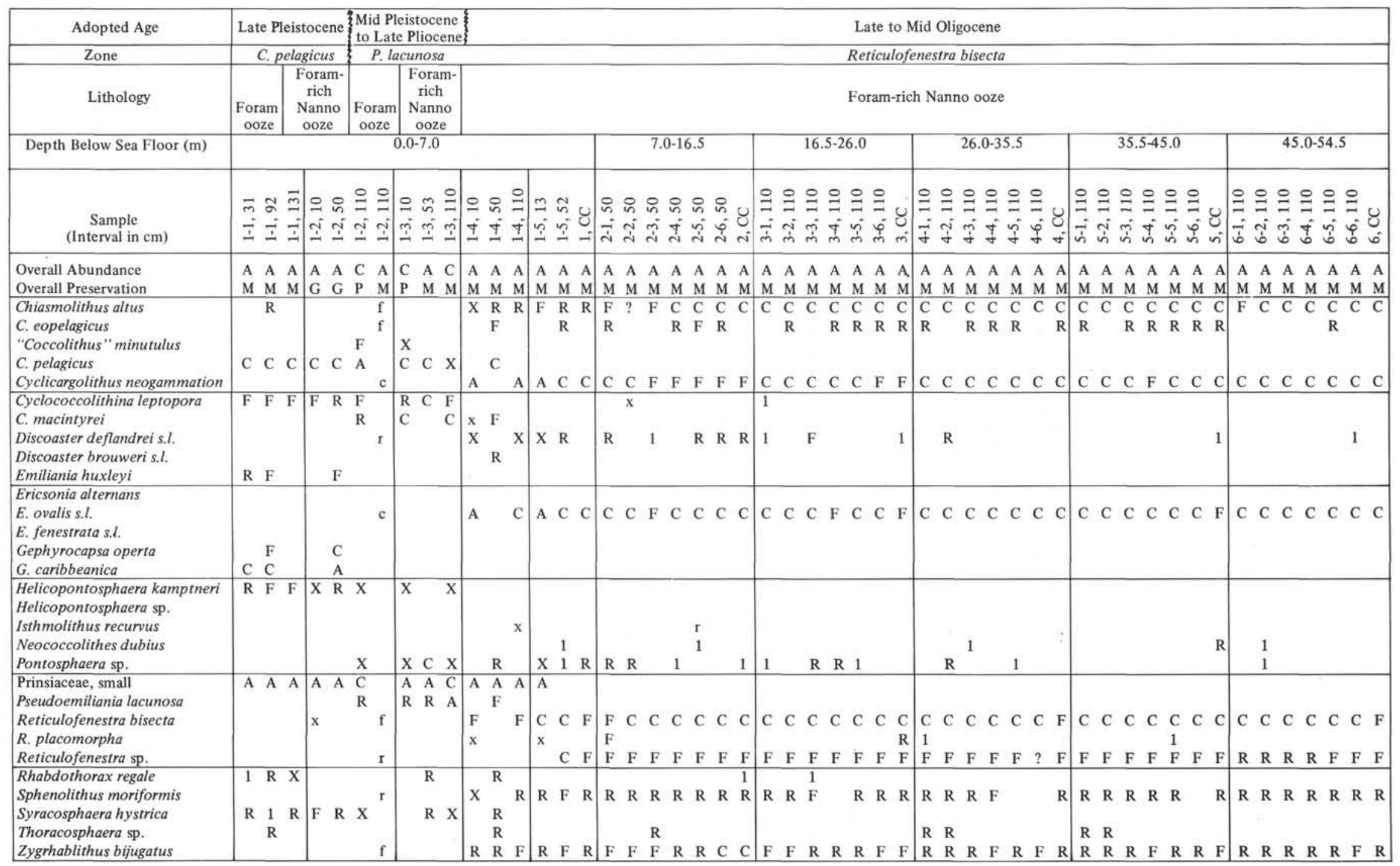

Note: $\mathrm{A}=\mathrm{abundant} ; \mathrm{C}=$ common; $\mathrm{F}=\mathrm{few} ; \mathrm{R}=\mathrm{rare} ; \mathrm{X}=1-5$ specimens; $\mathrm{l}=1$ specimen; $+=$ present trace; and $=$ absent. These symbols are in lower case when specimens are thought to be reworked or contaminated. $\mathrm{G}=$ good; $\mathrm{M}=$ moderate; and $\mathrm{P}=$ poor preservation. 
TABLE 4A - Continued

\begin{tabular}{|c|c|c|c|c|c|c|c|}
\hline Adopted Age & \multicolumn{7}{|c|}{ Late to Mid Oligocene } \\
\hline Zone & \multirow{2}{*}{\multicolumn{7}{|c|}{ Reticulofenestra bisecta }} \\
\hline Lithology & & & & & & & \\
\hline Depth Below Sea Floor (m) & $54.5-64.0$ & $64.0-73.5$ & $73.5-83.0$ & $83.0-92.5$ & $92.5-102.0$ & $102.0-111.5$ & $115.5-121.0$ \\
\hline $\begin{array}{c}\text { Sample } \\
\text { (Interval in cm) }\end{array}$ &  &  &  &  &  &  & 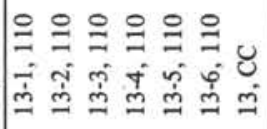 \\
\hline $\begin{array}{l}\text { Overall Abundance } \\
\text { Overall Preservation }\end{array}$ & $\begin{array}{llllll}\mathrm{A} & \mathrm{A} & \mathrm{A} & \mathrm{A} & \mathrm{A} & \mathrm{A} \\
\mathrm{M} & \mathrm{M} & \mathrm{M} & \mathrm{M} & \mathrm{M} & \mathrm{M} \\
\end{array}$ & $\begin{array}{lllllll}\mathrm{A} & \mathrm{A} & \mathrm{A} & \mathrm{A} & \mathrm{A} & \mathrm{A} & \mathrm{A} \\
\mathrm{M} & \mathrm{M} & \mathrm{M} & \mathrm{M} & \mathrm{M} & \mathrm{M} & \mathrm{M} \\
\end{array}$ & $\begin{array}{lllllll}\mathrm{A} & \mathrm{A} & \mathrm{A} & \mathrm{A} & \mathrm{A} & \mathrm{A} & \mathrm{A} \\
\mathrm{M} & \mathrm{M} & \mathrm{M} & \mathrm{M} & \mathrm{M} & \mathrm{M} & \mathrm{M} \\
\end{array}$ & $\begin{array}{lllllll}\text { A } & \text { A } & \text { A } & \text { A } & \text { A } & \text { A } & \text { A } \\
\text { M } & \text { M } & \text { M } & \text { M } & \text { M } & \text { M } & \text { M }\end{array}$ & \begin{tabular}{|lllllll}
$\mathrm{A}$ & $\mathrm{A}$ & $\mathrm{A}$ & $\mathrm{A}$ & $\mathrm{A}$ & $\mathrm{A}$ & $\mathrm{A}$ \\
$\mathrm{M}$ & $\mathrm{M}$ & $\mathrm{M}$ & $\mathrm{M}$ & $\mathrm{M}$ & $\mathrm{M}$ & $\mathrm{M}$ \\
\end{tabular} & \begin{tabular}{|lllllll}
$\mathrm{A}$ & $\mathrm{A}$ & $\mathrm{A}$ & $\mathrm{A}$ & $\mathrm{A}$ & $\mathrm{A}$ & $\mathrm{A}$ \\
$\mathrm{M}$ & $\mathrm{M}$ & $\mathrm{M}$ & $\mathrm{M}$ & $\mathrm{M}$ & $\mathrm{M}$ & $\mathrm{M}$ \\
\end{tabular} & $\begin{array}{lllllll}\mathrm{A} & \mathrm{A} & \mathrm{A} & \mathrm{A} & \mathrm{A} & \mathrm{A} & \mathrm{A} \\
\mathrm{M} & \mathrm{M} & \mathrm{M} & \mathrm{M} & \mathrm{M} & \mathrm{M} & \mathrm{M} \\
\end{array}$ \\
\hline $\begin{array}{l}\text { Chiasmolithus altus } \\
\text { C. eopelagicus } \\
\text { "Coccolithus" minutulus } \\
\text { C. pelagicus } \\
\text { Cyclicargolithus neogammation }\end{array}$ & $\begin{array}{llllll}C & C & F & C & C & C \\
& & & R & R & R \\
& & & & & \\
& & & & & \\
C & C & C & C & & \\
C & & & & \end{array}$ & $\begin{array}{lllllll}\text { C } & \text { C } & \text { C } & \text { C } & \text { C } & \text { C } & C \\
& & & R & R & R & R \\
& & & & & & \\
& & & & & & \\
\text { C } & \text { F } & \text { C } & \text { A } & \text { A } & \text { A } & \text { A }\end{array} \mid$ & $\begin{array}{lllllll}C & C & C & C & C & C & C \\
& R & R & R & R & R & R \\
& & & & & & \\
C & & & & & & \\
C & C & C & C & C & C & C\end{array} \mid$ & $\begin{array}{lllllll}C & F & C & F & C & C & F \\
& R & & & R & R & \\
& & & & & & \\
& & & & & & \\
C & F & C & F & C & C & A\end{array}$ & $\left|\begin{array}{lllllll}C & C & C & C & C & F & C \\
& & & R & R & R \\
& & & & & & \\
& & & & & & \\
C & C & C & F & C & F & R\end{array}\right|$ & $\left|\begin{array}{ccccccc}C & C & C & C & C & F & C \\
& R & R & R & & R \\
& & & & & \\
& C & C & & & & \\
C & C & C & C & C & C\end{array}\right|$ & $\begin{array}{llllllll}\text { C } & C & C & C & C & C & C \\
& & & R & R & R & R \\
& & & & & & \\
& & & & & & & \\
\text { F } & C & C & C & C & F & C\end{array}$ \\
\hline $\begin{array}{l}\text { Cyclococcolithina leptopora } \\
\text { C. macintyrei } \\
\text { Discoaster deflandrei s.l. } \\
\text { Discoaster brouweri s.l. } \\
\text { Emiliania huxleyi }\end{array}$ & & 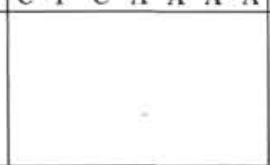 & & & & & \\
\hline $\begin{array}{l}\text { Ericsonia alternans } \\
\text { E. ovalis s.l. } \\
\text { E. fenestrata s.l. } \\
\text { Gephyrocapsa operta } \\
\text { G. caribbeanica } \\
\end{array}$ & 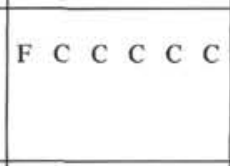 & 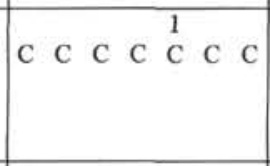 & 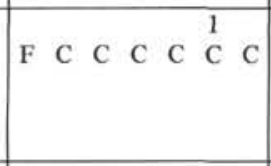 & 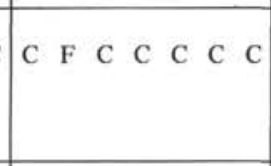 & $\begin{array}{lllllll}C & C & C & C & C & C & C\end{array}$ & 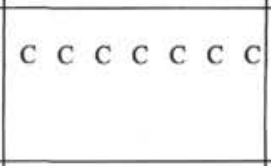 & $\begin{array}{ccccccc}C & C & C & C & C & C & C\end{array}$ \\
\hline $\begin{array}{l}\text { Helicopontosphaera kamptneri } \\
\text { Helicopontosphaera sp. } \\
\text { Isthmolithus recurvus } \\
\text { Neococcolithes dubius } \\
\text { Pontosphaera sp. }\end{array}$ & 1 & $\begin{array}{ll}1 & \mathrm{R} \\
& \\
& 1\end{array}$ & 1 & 1 & $\begin{array}{l}1 \\
1 \\
1\end{array}$ & $1^{1}$ & 1 \\
\hline $\begin{array}{l}\text { Prinsiaceae, small } \\
\text { Pseudoemiliania lacunosa } \\
\text { Reticulofenestra bisecta } \\
\text { R. placomorpha } \\
\text { Reticulofenestra sp. }\end{array}$ & $\begin{array}{llllll}\text { C } & C & C & C & C & C \\
\text { F } & F & F & \text { R } & \text { F } & \text { F }\end{array}$ & $\begin{array}{lllllll}C & C & C & C & C & C & C \\
F & F & F & F & F & F & F\end{array}$ & $\begin{array}{lllllll}\text { C } & C & C & C & C & C & C \\
F & F & F & F & R & & \\
F & F & F\end{array}$ & $\begin{array}{lllllll}C & F & C & F & C & C & C \\
F & R & & & & & \\
F & R & F & R & F\end{array}$ & $\begin{array}{lllllll}C & C & F & C & F & C & F \\
F & F & F & R & F & F & R\end{array}$ & $\mid \begin{array}{ccccccc}C & C & C & C & C & F & F \\
& & & & 1 & & 1 \\
F & F & F & R & R & F & F\end{array}$ & $\begin{array}{lllllll}C & C & F & C & F & R & C \\
F & F & F & F & F & F & F\end{array}$ \\
\hline $\begin{array}{l}\text { Rhabdothorax regale } \\
\text { Sphenolithus moriformis } \\
\text { Syracosphaera hystrica } \\
\text { Thoracosphaera sp. } \\
\text { Zygrhablithus bijugatus } \\
\end{array}$ & $\begin{array}{lllllll}R & R & F & R & R & R \\
& & & & & \\
R & R & R & R & R & R \\
\end{array}$ & \begin{tabular}{|lllllll}
$F$ & $R$ & $R$ & $F$ & $R$ & $R$ \\
& & & & & \\
$R$ & $R$ & $R$ & $R$ & $F$ & $F$ & $F$ \\
\end{tabular} & $\begin{array}{lllllll}F & R & R & R & R & F & F \\
& & & & & & \\
F & F & F & F & R & R & F \\
\end{array}$ & $\begin{array}{llllllll}R & R & R & R & F & F & R \\
& & & & & & \\
F & R & R & F & F & R & F\end{array}$ & $\begin{array}{lllllll}R & F & R & R & R & & R \\
& & & & & & \\
& & & & & R & \\
F & F & F & R & F & F & R\end{array}$ & $\begin{array}{llll}R & R & R & R \\
& & \\
R & R & R \\
\end{array}$ & $\begin{array}{lllllllll} & & 1 & & & \\
R & R & R & R & R & R & R \\
& & & & & & \\
R & & & & R & R \\
R & R & R & R & R & R & R \\
\end{array}$ \\
\hline
\end{tabular}


TABLE 4B

Calcareous Nannofossil Distribution, Site 277



Note: See Table 4A for explanation of symbols.

lithologically controlled diagenetic effects. It is then necessary to attempt to determine the reason for the deposition of different lithologies.

4) Drilling and coring, especially in the usually soupy or very soft uppermost layers, can produce mixed coccolith assemblages. These are sometimes not recognized as such, resulting in incorrect conclusions.

5) The preparation of smear slides varies from scientist to scientist. A certain amount of sorting during drying of the sample often cannot be avoided. Thus a slide may have a "residual" winnowed assemblage with mainly large forms in the central part, surrounded by a more or less normal, "true" assemblage, with an assemblage consisting mainly of smaller forms towards the edges of the slide.

Some of the ecological factors which affect the vertical and horizontal distribution of living calcareous nannoplankton are well known. Certainly others are still unknown. However, most species occurring in sediments older than Pliocene are extinct. Our conclusions about the paleoecological significance of these species are, of necessity, based on analogy with the results of previous investigations in areas where certain ecological conditions were assumed to be present.

The presence of more or less common Zygrhablithus bijugatus is considered to indicate deposition in water depths well above the lysocline, as this species seems to dissolve easily. Edwards (1973c) came to similar conclusions regarding DSDP Leg 21 material. However, the writers cannot yet explain why the possibly related Late Cretaceous species Lucianorhabdus cayeuxi is among the species most resistant to diagenesis in the Baltic chalk. $Z$. bijugatus was found to be consistently present and often common in the late Paleocene to Oligocene sediments of Site 277 on the Campbell Plateau (present depth, $1222 \mathrm{~m}$ ). It is very rare in a very few EoceneOligocene samples at Site 280 south of Tasmania (present depth, $4181 \mathrm{~m}$ ), and rare to few Z. bijugatus occur in the Oligocene of Site 281, just north of Site 280 (present depth, $1591 \mathrm{~m}$ ). The presence of few to common $\mathrm{Z}$. bijugatus in selected samples only of Oligocene and Eocene age at Site 282 (present depth, $4207 \mathrm{~m}$ ) is at- 
TABLE 4B - Continued



tributed to occasional rapid transport and burial of coccoliths and nannoliths from the nearby shelf of Tasmania and southern Australia. Z. bijugatus is missing at Site 283 (4746 m, present depth), although coccolith-bearing Eocene sediments were found.

At most sites of Leg 29, representatives of the Pontosphaeraceae (except Helicopontosphaera) are rare or absent. This is also true of the Braarudosphaeraceae. Both are well known for their preference for nearshore environments. These conclusions are consistent with New Zealand and DSDP Leg 21 experience (Edwards, 1968; 1973b). Pontosphaerids often occur as few to common in samples containing common Braarudosphaeraceae, as well as when the latter are rare.

The ratio between discoasters, considered to be warm water forms because of their abundance in sediments deposited in tropical seas, and Chiasmolithus, representative of cooler conditions, has been used as an indication of changing climates (Bukry, 1973). Chiasmolithus occurs from the Paleocene through to the Oligocene whereas discoasters last until the end of the Pliocene (by definition) in warm areas, but are absent earlier in cool water areas. No counts were made of discoasters and Chiasmolithus in Leg 29 samples. Some trends, however, can be extracted from the observations made so far and are tabulated in Tables 4-12.

In the late Paleocene of Site 277, discoasters are initially more frequent than Chiasmolithus but a reversal occurs near the top. Above this Chiasmolithus dominates over discoasters until both groups reach similar frequencies in the late early Eocene to early mid Eocene interval. Discoasters are rare or usually absent throughout the remainder of the Eocene and the Oligocene, whereas various species of Chiasmolithus flourish. This pattern is considered to indicate a temporary cooling of the climate across the late Paleocene-early Eocene boundary, relatively warmer conditions again in the late early Eocene and early mid Eocene, and finally cooler conditions for the remainder of the Eocene and most of the Oligocene. These conclusions are consistent with the distribution of warm water nannoliths excluding discoasters and the cosmopolitan Sphenolithus moriformis group. In the entire Paleogene sequence of Site 277 these nannoliths are only represented by Fasciculithus tympaniformis (common in the late mid Paleocene to mid late Paleocene interval), and Sphenolithus radians (rare in the early to mid early Eocene and rare to few in the late early Eocene and early mid Eocene). A similar 
TABLE 4C

Calcareous Nannofossil Distribution, Site 277

\begin{tabular}{|c|c|c|c|c|c|c|c|c|c|c|c|c|c|c|c|c|c|c|c|c|c|c|c|c|c|}
\hline Adopted Age & \multicolumn{14}{|c|}{ Mid Eocene } & \multicolumn{8}{|c|}{ Early Eocene } & \multicolumn{2}{|c|}{ Late Paleocene } & \multirow{2}{*}{ 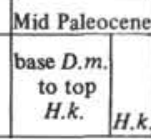 } \\
\hline Zone & \multicolumn{7}{|c|}{$\begin{array}{l}\text { base } C \text {. reticulata to } \\
\text { base } R \text {. hampdenensis }\end{array}$} & \multicolumn{4}{|c|}{$\mid \begin{array}{c}\text { base } R \text {. hamp. } \\
\text { denensis to base } \\
R \text {. placomorpha }\end{array}$} & \multicolumn{2}{|c|}{$\mid$\begin{tabular}{|c|} 
base \\
$R . p$. \\
to top \\
$D . K$.
\end{tabular}} & \multicolumn{5}{|c|}{$\begin{array}{c}\text { top } D . \text { kuepperi to base } \\
R \text {. dictyoda }\end{array}$} & \multicolumn{3}{|c|}{$\begin{array}{l}\text { base } R \text {. dictyoda to base } \\
\text { D. kuepperi }\end{array}$} & $\begin{array}{c}\text { base } D . \\
\text { kuepperi to top } \\
D . \text { multiradiatus }\end{array}$ & \multicolumn{2}{|c|}{ Discoaster multiradiatus } & \\
\hline Lithology & \multicolumn{25}{|c|}{ Nanno chalk } \\
\hline Depth Below Sea Floor $(\mathrm{m})$ & $\begin{array}{r}311.0 \\
320.5\end{array}$ & & & $\begin{array}{l}30.0- \\
39.5\end{array}$ & & $\begin{array}{l}349.0- \\
358.5\end{array}$ & & & $8.0-$ & & & $\begin{array}{l}77.5 . \\
87.0\end{array}$ & & $\begin{array}{l}387.0- \\
396.5\end{array}$ & $\begin{array}{l}396.5- \\
406.0\end{array}$ & & $\begin{array}{l}406.0- \\
415.5\end{array}$ & & $\begin{array}{l}415.5- \\
425.0\end{array}$ & $\begin{array}{l}425.0- \\
434.5\end{array}$ & $434.0-444.0$ & \multicolumn{2}{|c|}{$444.0-453.5$} & $453.5-463.0$ & $463.0-472.5$ \\
\hline $\begin{array}{c}\text { Sample } \\
\text { (Interval in } \mathrm{cm} \text { ) }\end{array}$ & 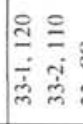 & & & $\begin{array}{l}\stackrel{0}{=} \\
\text { i } 8 \\
\text { में में }\end{array}$ & & 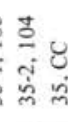 & & $\frac{\infty}{i}$ & & & & & & 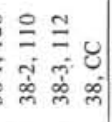 & 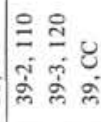 & & 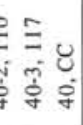 & & 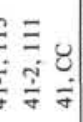 & 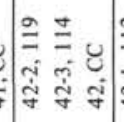 & 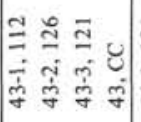 & 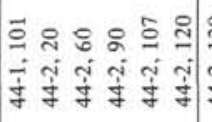 & $\mid$ &  & 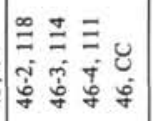 \\
\hline $\begin{array}{l}\text { verall Abundance } \\
\text { verall Preservation }\end{array}$ & $\mathrm{A}$ & & & $\begin{array}{ll}\mathrm{A} & \mathrm{A} \\
\mathrm{M} & \mathrm{M}\end{array}$ & & $\begin{array}{ll}A & A \\
M & M\end{array}$ & & A & $\begin{array}{l}\mathrm{A} \\
\mathrm{M}\end{array}$ & & & $\begin{array}{ll}\mathrm{C} & \mathrm{A} \\
\mathrm{P} & \mathrm{P}\end{array}$ & & $\begin{array}{lll}\mathrm{A} & \mathrm{A} & \mathrm{A} \\
\mathrm{M} & \mathrm{M} & \mathrm{M}\end{array}$ & $\begin{array}{lll}\mathrm{C} & \mathrm{A} & \mathrm{A} \\
\mathrm{P} & \mathrm{M} & \mathrm{M}\end{array}$ & & $\begin{array}{lll}A & A \\
M & M & M\end{array}$ & & $\begin{array}{lll}A & C & A \\
M & M & P\end{array}$ & $\left|\begin{array}{lll}\text { A } & \text { A } & \text { A } \\
\text { M } & \text { M } & \text { P }\end{array}\right|$ & \begin{tabular}{llll|}
$\mathrm{A}$ & $\mathrm{A}$ & $\mathrm{A}$ & $\mathrm{A}$ \\
$\mathrm{P}$ & $\mathrm{M}$ & $\mathrm{M}$ & $\mathrm{P}$
\end{tabular} & $\begin{array}{llllll}C & C & A & A & C & C \\
M & M & M & M & P & M\end{array} \mid$ & $\begin{array}{llllll}C & C & C & C & C & A \\
M & M & M & M & M & P\end{array} \mid$ & $\begin{array}{lllllll}C & C & C & C & C & C & d \\
M & M & M & M & P & M & P\end{array}$ & $\begin{array}{llll}\mathrm{C} & \mathrm{C} & \mathrm{C} & \mathrm{C} \\
\mathrm{P} & \mathrm{P} & \mathrm{P} & \mathrm{P}\end{array}$ \\
\hline $\begin{array}{l}\text { Biscutum panis } \\
\text { Chiasmolithus eograndis } \\
\text { C. expansus } \\
\text { C. grandis } \\
\text { C. solitus }+C \text {. } \mathrm{sp} \text {. }\end{array}$ & $\begin{array}{lll}\mathrm{F} & \mathrm{R} \\
\mathrm{R} & \\
\mathrm{C} & \mathrm{C} & \\
\end{array}$ & & & & & $\begin{array}{ll}\mathrm{F} & \mathrm{R} \\
\mathrm{R} & \\
\mathrm{C} & \mathrm{C}\end{array}$ & & $\mathrm{F}$ & $\begin{array}{ll}\mathrm{R} & \mathrm{R} \\
\mathrm{R} & \mathrm{P} \\
\mathrm{C} & \mathrm{C}\end{array}$ & & $\begin{array}{l}\mathrm{R} \\
\mathrm{R} \\
\mathrm{C}\end{array}$ & $\begin{array}{ll}\mathrm{F} & \mathrm{F} \\
\mathrm{C} & \mathrm{C}\end{array}$ & & 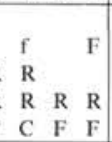 & $\begin{array}{lll}R & R & R \\
F & F & C \\
\end{array}$ & 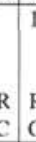 & F F F & & $\begin{array}{lll} & & R \\
R & F \\
& F & \\
F & F \\
\end{array}$ & $\mid \begin{array}{lll}R & R & R \\
F & F & F \\
& & \\
F & F & F\end{array}$ & $\begin{array}{|llll|}R & & & \\
F & C & C & R \\
\end{array}$ & $C F \mathrm{C}$ & \begin{tabular}{llllll|} 
& $R$ & $R$ & $R$ & $R$ & $R$ \\
$F$ & $R$ & $C$ & $C$ & $C$ & $F$
\end{tabular} & \begin{tabular}{|lllllll} 
C & & 1 & & & \\
F & $R$ & $R$ & $R$ & $R$ & & $R$ \\
\end{tabular} & $\begin{array}{l}\mathrm{T} \\
\mathrm{R}\end{array}$ \\
\hline $\begin{array}{l}\text { Conococcolithus? sp. } \\
\text { Cruciplacolithus staurion } \\
\text { Cruciplacolithus sp. } \\
\text { Discoaster barbadiensis } \\
\text { D. diastypus }\end{array}$ & $?$ & & & $\mathrm{R} R$ & $R$ & & 1 & & & & 1 & & & $R$ & $\begin{array}{lll}1 & & 1 \\
1 & 1 & 1\end{array}$ & & F C & & $\mathrm{F} F$ & 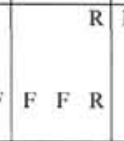 & $\begin{array}{|llll|}F & R & R & R \\
& R & R & \\
& & & \\
& & & R\end{array}$ & $\begin{array}{lllll}R & R & R & R & R \\
& R & R \\
& R & \\
R & R & R & R\end{array}$ & & & \\
\hline $\begin{array}{l}\text { D. kuepperi } \\
\text { D. lodoensis } \\
\text { D. multiradiatus } \\
\text { D. sublodoensis-? } \\
\text { D. wemmelensis }\end{array}$ & & 1 & & & 1 & R F & & $\mathrm{F}$ & & & $\begin{array}{l}\mathrm{R} \\
1\end{array}$ & & & $\begin{array}{ccc}R & F & R \\
C & F \\
F ? & \\
1 & 1 \\
\end{array}$ & $\begin{array}{lll}\mathrm{R} & \mathrm{R} & \mathrm{F} \\
\mathrm{R} & 1 & \mathrm{R} \\
? & & ?\end{array}$ & & \begin{tabular}{ll|}
$R$ & $F$ \\
$R$ & $F$ \\
& \\
& $?$
\end{tabular} & $\begin{array}{l}\mathrm{F} \\
\mathrm{R}\end{array}$ & $\begin{array}{lll}F & F & F \\
R & R & R\end{array}$ & $\left|\begin{array}{lll}F & R & R \\
1 & & R\end{array}\right|$ & $\begin{array}{lllll} & R & R & F\end{array}$ & $\mathrm{R} R$ & $R \quad R \quad R \quad R$ & 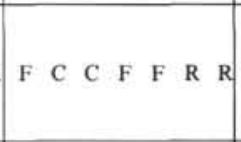 & \\
\hline $\begin{array}{l}\text { Discoaster sp. } \\
\text { Ellipsolithus macellus } \\
\text { Ericsomia alternamus } \\
\text { E. copelagica } \\
\text { E. fenestrata s.l. }\end{array}$ & $\begin{array}{lll}R & \\
R & \\
R & F \\
F & R\end{array}$ & \begin{tabular}{l|l}
$\mathrm{R}$ & \\
$\mathrm{R}$ & \\
$\mathrm{R}$
\end{tabular} & $\begin{array}{l}R \\
R \\
R\end{array}$ & $\begin{array}{ll} & \mathrm{F} \\
\mathrm{R} & \mathrm{R} \\
\mathrm{F} & \mathrm{F} \\
\mathrm{R} & \mathrm{R}\end{array}$ & $\begin{array}{l}F \\
R \\
F\end{array}$ & $\begin{array}{ll}F & R \\
R & R \\
R & R \\
R & F\end{array}$ & & $\begin{array}{l}R \\
R \\
F\end{array}$ & $\begin{array}{ll}\mathrm{R} & \mathrm{F} \\
\mathrm{R} & \mathrm{F}\end{array}$ & & & $\begin{array}{ll}\mathrm{F} & \mathrm{R} \\
\mathrm{R} & 1 \\
\mathrm{R} & \mathrm{R}\end{array}$ & $\begin{array}{l}1 \\
R\end{array}$ & $\begin{array}{lll}C & F & F \\
& 1 & \\
F & F & F \\
R & F & R\end{array}$ & $\begin{array}{lll}F & F & F \\
& 1 & \\
F & F & F \\
F & F & F\end{array}$ & & $\begin{array}{ll}F & C \\
R & R \\
F & F\end{array}$ & & $\begin{array}{ll}F & F \\
R & R \\
R\end{array}$ & F F F & $\mathbf{R}$ & $\begin{array}{|llllll|} & 1 & & & & \\
& R & R & R & R & R \\
& & & & & \\
& & R & & & \\
\end{array}$ & $\begin{array}{ll}R & 1\end{array}$ & $\mathrm{R} R$ & \\
\hline \begin{tabular}{|l|} 
E. oralis \\
Fasciculithus tympaniformis \\
Heliolithus klcinpellii \\
Hornibrookiana australis \\
Markalius astroporus \\
\end{tabular} & c C & $\mathrm{R}$ & C & C C & C & $\mathrm{CC}$ & C & $\mathrm{CO}$ & $\mathrm{CO}$ & & & $\mathrm{C} \mathrm{C}$ & C & $\begin{array}{c}\mathrm{C} C \mathrm{C} \\
1\end{array}$ & C C C & c $\mathrm{c}$ & $\mathrm{CC} \mathrm{C}$ & & $\begin{array}{lll}C & C & c \\
& 1 \\
1 & & \end{array}$ & $\left|\begin{array}{ccc}C & C & C \\
& 1 & 1 \\
R & F & F\end{array}\right|$ & $\begin{array}{lllll}\text { C } & \text { C } & \text { C } & \text { C } \\
& & & & 1 \\
& & & \\
\text { F } & \text { F } & \text { R } & \text { R }\end{array} \mid$ & $\begin{array}{|llllll|}\text { C } & \text { C } & \text { C } & \text { C } & \text { C } & \text { C } \\
& & & & & \\
\text { sp. } & \text { sp. } & \text { sp, sp. } & & \\
& & R & & F & R \\
R & R & F & F & & R\end{array}$ & $\begin{array}{|cccccc|}\text { C } & \text { C } & \text { C } & \text { C } & \text { C } & \text { C } \\
1 & & 1 & 1 & R & R \\
& & & & & \\
& F & F & C & F & R \\
R & R & F & R & R & R\end{array}$ & $\mid \begin{array}{lllllll}C & F & F & F & F & F & R \\
F & C & C & C & C & C & C \\
& & & & & & \\
F & C & R & & & & \\
F & F & F & & & & R\end{array}$ & 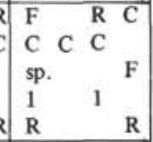 \\
\hline $\begin{array}{l}\text { Neochiastozygus concinnus } \\
\text { N. distentus } \\
\text { Neococcolithes dubius s.t. } \\
\text { Pontosphaera sp. } \\
\text { Marthasterites tribrachiatus }\end{array}$ & F R & & & F F & $\mathrm{F}$ & $F F$ & $=c$ & $=\mathrm{c}$ & C F & & & C C & & $\begin{array}{lll}C & C & C \\
1\end{array}$ & F F F & & $F F F$ & & 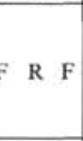 & R F F & $\begin{array}{|llll|}\mathrm{F} & \mathrm{F} & \mathrm{R} & \\
\mathrm{R} & & \mathrm{R} & \\
& & & \mathrm{R} \\
\end{array}$ & $\begin{array}{|llllll|} & & 1 & & \\
R & R & R & R & R & \\
R & & & R & R \\
& 1 & & & 1 & \\
& & & & \end{array}$ & 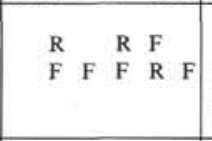 & $\begin{array}{lll} & & R \\
F & C & \\
R & & \end{array}$ & F R \\
\hline $\begin{array}{l}\text { Reticulofenestra cf. } R \text {. bisecta } \\
R \text {. cf. } R \text {. dictyoda } \\
R \text {. hampdenensis } \\
\text { R. placomorpha } \\
\text { Rhabdolithus sp. }\end{array}$ & $\begin{array}{ll}F & F \\
A & C \\
R & R \\
C & C \\
F & R \\
\end{array}$ & \begin{tabular}{l|}
$\mathrm{F}$ \\
$\mathrm{F}$ \\
$\mathrm{R}$ \\
$\mathrm{C}$
\end{tabular} & \begin{tabular}{|l}
$\mathrm{F}$ \\
$\mathrm{C}$ \\
$\mathrm{R}$ \\
$\mathrm{C}$ \\
$\mathrm{R}$
\end{tabular} & $\begin{array}{ll}R & R \\
C & F \\
R & F \\
F & F \\
F & R\end{array}$ & $\begin{array}{l}F \\
A \\
F \\
F \\
R\end{array}$ & $\begin{array}{ll}F & R \\
A & C \\
F & R \\
F & F \\
R & B\end{array}$ & $\begin{array}{ll}R \\
R \\
R \\
R \\
R\end{array}$ & $\begin{array}{ll}R & F \\
A & A \\
R & F \\
R & R\end{array}$ & $\begin{array}{lll}\mathrm{F} & \mathrm{P} \\
\mathrm{A} & \mathrm{A} & \\
\mathrm{R} & \mathrm{F} \\
\mathrm{R} & \mathrm{F}\end{array}$ & \begin{tabular}{l|}
$\mathrm{F}$ \\
$\mathrm{A}$ \\
$\mathrm{R}$ \\
$\mathrm{R}$
\end{tabular} & c & $\begin{array}{ll}\mathrm{F} & \mathrm{F} \\
\mathrm{C} & \mathrm{C}\end{array}$ & F & $\mathrm{c} \quad \mathrm{c}$ & c C C & & $\mathrm{C} \mathrm{F} \mathrm{C}$ & & & & & & & & \\
\hline $\begin{array}{l}\text { Sphenolithus moriformis } \\
\text { S. radians } \\
\text { Thoracosphaera sp. } \\
\text { Toweius? sp., large } \\
\text { Zygrhablithus bijugatus s.I. }\end{array}$ & $F$ & \begin{tabular}{l|}
$\mathrm{F}$ \\
$\mathrm{R}$
\end{tabular} & & $\begin{array}{ll}\text { R } & F \\
\text { F } & F \\
\text { F } & F\end{array}$ & $\mathrm{~F}$ & $\mathrm{R}$ & $\mathrm{F}$ & $\mathrm{R}$ & R F & $\mathbf{R}$ & & $\begin{array}{lll}R & R \\
R & R\end{array}$ & & $\begin{array}{lll}F & R & R \\
F & F & R \\
R & R & R \\
C & C & C\end{array}$ & $\begin{array}{lll}F & F & F \\
R & F & F \\
C & F & F \\
1 & & 1 \\
C & C & C\end{array}$ & $\begin{array}{lll}\mathrm{F} & 1 \\
\mathrm{~F} & 1 \\
\mathrm{~F} & 1 \\
1 & \\
\mathrm{C} & & \end{array}$ & $\begin{array}{lll}F & F & F \\
F & R & F \\
F & F & F \\
\text { F } & F & R \\
C & C & A\end{array}$ & & $\begin{array}{lll}R & F & R \\
R & R & R \\
F & F & F \\
R & R \\
A & C & A\end{array}$ & $\left|\begin{array}{lll}C & F & F \\
R & F & F \\
F & F & F \\
C & C & A\end{array}\right|$ & $\mid \begin{array}{llll}\mathrm{F} & \mathrm{R} & \mathrm{F} & \mathrm{F} \\
\mathrm{R} & \mathrm{R} & \mathrm{R} & \mathrm{R} \\
\mathrm{F} & \mathrm{F} & \mathrm{R} & \\
& \mathrm{R} & & \\
\mathrm{C} & \mathrm{A} & \mathrm{A} & \mathrm{A}\end{array}$ & $\begin{array}{|llllll|}\mathrm{F} & \mathrm{F} & \mathrm{F} & \mathrm{F} & \mathrm{F} & \mathrm{F} \\
\mathrm{R} & \mathrm{X} & \mathrm{R} & & & \\
\mathrm{R} & \mathrm{R} & \mathrm{R} & \mathrm{R} & \mathrm{R} \\
\mathrm{R} & \mathrm{C} & \mathrm{C} & \mathrm{F} & \mathrm{F} \\
\mathrm{A} & \mathrm{C} & \mathrm{C} & \mathrm{C} & \mathrm{A} & \mathrm{F}\end{array}$ & \begin{tabular}{llllll|} 
F & $F$ & $F$ & $C$ & $C$ & $C$ \\
$R$ & $R$ & $F$ & $R$ & $F$ & $F$ \\
$C$ & $R$ & $C$ & $C$ & $C$ & $C$ \\
$C$ & $F$ & $F$ & $F$ & $C$ & $C$
\end{tabular} & $\begin{array}{lllllll}C & F & F & F & R & F & F \\
C & C & F & F & F & R & F \\
C & & R & C & C & F & F \\
C & C & 1 & & & & \end{array}$ & $F R^{R}$ \\
\hline
\end{tabular}

Note: See Table 4A for explanation of symbols. 
TABLE 5A

Calcareous Nannofossil Distribution, Site 278

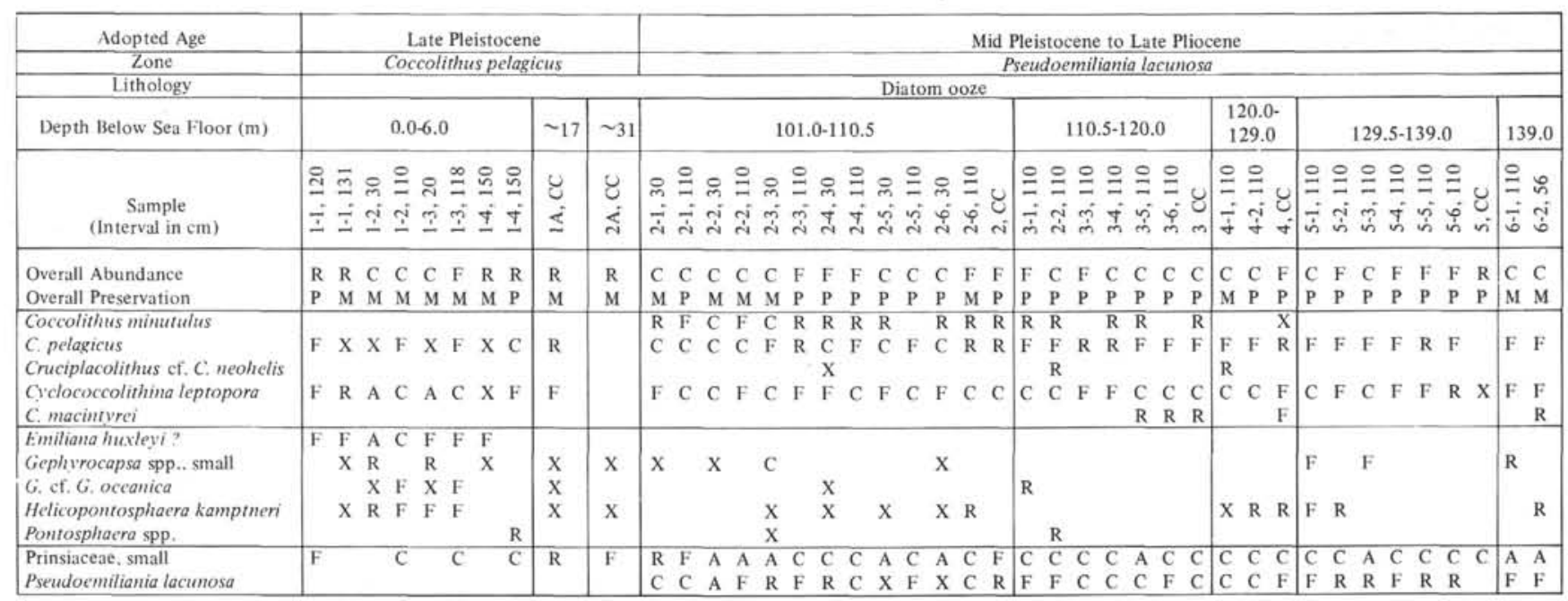

Note: See Table $4 \mathrm{~A}$ for explanation of symbols.

pattern has been observed in New Zealand and southern DSDP Leg 21 samples.

At Site 278, Chiasmolithus is common to abundant in the mid and late Oligocene; discoasters are usually absent. Very rare specimens (visitors) occur in a few samples in the latter part of the Oligocene. This site at present underlies the Antarctic Convergence.

In the poorly dated Oligocene and Eocene at Site 280, Chiasmolithus is absent or occasionally rare to common. Discoasters are absent. Here, the absence of Chiasmolithus is probably due to deposition just above the calcite compensation depth. As discoasters are known to be more resistant to dissolution than coccoliths, it can reasonably be concluded that the absence of discoasters is a primary feature, probably resulting from adverse climatic conditions.

At Site 281, Chiasmolithus is common in the early late Eocene, early Oligocene, and late Oligocene whereas discoasters only occur in low numbers in a short late Oligocene interval which follows a hiatus.

At Site 282, Chiasmolithus is as rare as the discoasters in the late Eocene but they become more frequent through the Oligocene where chiasmoliths dominate over the discoasters which are rare or, more usually, absent.

Where Paleogene calcareous nannofossils are present in reasonable numbers at Site 283. (early late Eocene) Chiasmolithus dominates over the very rare discoasters.

These observations on the frequency relationships of discoasters and Chiasmolithus strongly support the use of this ratio as a tool to detect changes in paleoconditions, possibly in terms of paleotemperatures.

Observations on the Neogene Leg 29 occurrences of discoasters show the following. (1) Discoasters are conspicuously common in the early Miocene sediments of Sites 279,281 , and 282 , but much rarer in the underlying and overlying assemblages (see Site Reports, Chapters 6, 8 , and 9 , this volume). This pattern is so pronounced at these sites that the simple observation that a sample of unknown age contains common discoasters is sufficient to date it as early Miocene! A similar but less pronounced pattern occurs in equivalent age sediments in New Zealand, and at the southern DSDP Leg 21 sites. This pattern coincides with the strongest indications for warm climate in New Zealand (Hornibrook, 1971). (2) This pattern does not extend as far south as Site 278. At this site, which at present underlies the Antarctic Convergence, discoasters are very rare and sporadic throughout the entire sequence. Even the cosmopolitan Sphenolithus moriformis group s.l. is rare and sporadic in its Neogene occurrences. At this site it would seem advisable to consider all discoasters as "visitors." (3) In Leg 29 sediments the last appearance of discoasters, which in warm water areas is considered to coincide with the Plio-Pleistocene boundary, is clearly climatically controlled. For example, at Site $284\left(40^{\circ} \mathrm{S}\right)$ their last appearance appears to approximate their extinction in warm water areas, but at Site $281\left(48^{\circ} \mathrm{S}\right)$ their last occurrence (more than one specimen observed) occurs in the basal Pliocene, and at Site $278\left(56^{\circ} \mathrm{S}\right)$ their last occurrence probably occurs in the early mid Miocene. A similar but less extreme pattern has been observed in both the North Atlantic (Perch-Nielsen, 1972), and New Zealand.

\section{Southern and Northern High-Latitude Calcareous Nanno- fossils in the Cenozoic}

Calcareous nannofossils are currently widely used for intercontinental and interoceanic correlations of marine sediments. Several zonal schemes have been proposed for different areas and a "standard Tertiary and Quaternary calcareous nannoplankton zonation" was 
TABLE 5B

Calcareous Nannofossil Distribution, Site 278

\begin{tabular}{|c|c|c|c|c|c|c|}
\hline Adopted Age & \multicolumn{3}{|c|}{ Mid Pleistocene to Late Pliocene } & & & \\
\hline Zone & \multicolumn{3}{|c|}{ Pseudoemiliania lacunosa } & & & \\
\hline Lithology & \multicolumn{4}{|c|}{ Diatom ooze } & & \\
\hline Depth Below Sea Floor (m) & $139.0-148.5$ & $148.5-158.0$ & $158.0-167.5$ & & $167.5-177.0$ & $177.0-186.5$ \\
\hline $\begin{array}{c}\text { Sample } \\
\text { (Interval in } \mathrm{cm} \text { ) }\end{array}$ &  & 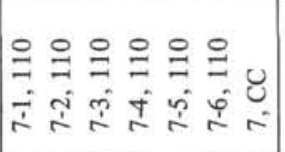 & 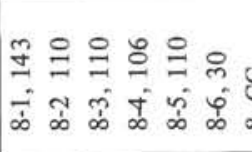 & $\begin{array}{ll}0 & 0 \\
0 & 0 \\
\infty & \infty\end{array}$ & 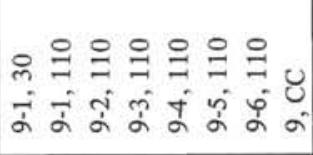 &  \\
\hline $\begin{array}{l}\text { Overall Abundance } \\
\text { Overall Preservation }\end{array}$ & $\begin{array}{llllll}\mathrm{C} & \mathrm{C} & \mathrm{F} & \mathrm{R} & \mathrm{F} & \mathrm{F} \\
\mathrm{M} & \mathrm{M} & \mathrm{M} & \mathrm{P} & \mathrm{P} & \mathrm{P}\end{array}$ & $\begin{array}{|lllllll|}\mathrm{F} & \mathrm{F} & \mathrm{F} & \mathrm{F} & \mathrm{F} & \mathrm{F} & \mathrm{R} \\
\mathrm{P} & \mathrm{P} & \mathrm{P} & \mathrm{P} & \mathrm{P} & \mathrm{P} & \mathrm{P} \\
\end{array}$ & $\begin{array}{l}-\mathrm{R}-\mathrm{C} \\
-\mathrm{P}-\mathrm{P} \\
\end{array}$ & $\begin{array}{ll}\mathrm{R} & \mathrm{C} \\
\mathrm{P} & \mathrm{P} \\
\end{array}$ & $\begin{array}{llllllll}\mathrm{A} & \mathrm{A} & \mathrm{A} & \mathrm{A} & \mathrm{A} & \mathrm{A} & \mathrm{A} & \mathrm{A} \\
\mathrm{P} & \mathrm{P} & \mathrm{P} & \mathrm{P} & \mathrm{P} & \mathrm{P} & \mathrm{P} & \mathrm{P} \\
\end{array}$ & $\begin{array}{lllll}\mathrm{A} & \mathrm{A} & \mathrm{A} & \mathrm{A} & \mathrm{A} \\
\mathrm{P} & \mathrm{P} & \mathrm{P} & \mathrm{P} & \mathrm{P} \\
\end{array}$ \\
\hline $\begin{array}{l}\text { Coccolithus eopelagicus s.l. } \\
\text { C. pelagicus group } \\
\text { Cyclicargolithus neogammation } \\
\text { Cyclococcolithina leptopora } \\
\text { C. macintyrei }\end{array}$ & $\begin{array}{llllll}\mathrm{F} & \mathrm{F} & \mathrm{F} & \mathrm{R} & \mathrm{F} & \mathrm{R} \\
& & & & & \\
\mathrm{R} & \mathrm{F} & \mathrm{F} & \mathrm{R} & \mathrm{R} & \mathrm{R} \\
\mathrm{R} & & & \mathrm{R} & & \end{array}$ & \begin{tabular}{|ccccccc}
$\mathrm{F}$ & $\mathrm{F}$ & $\mathrm{F}$ & $\mathrm{R}$ & $\mathrm{R}$ & $\mathrm{F}$ & $\mathrm{R}$ \\
& & & & & & \\
$\mathrm{R}$ & $\mathrm{R}$ & & & $\mathrm{R}$ & $\mathrm{F}$ & $\mathrm{R}$ \\
& & & $\mathrm{R}$ & & $\mathrm{R}$ & $\mathrm{X}$
\end{tabular} & C 1 & $\mathrm{R} \quad \mathrm{C}$ &  & $\begin{array}{lllll} & \text { R } & & \\
\text { R } & \text { F } & \text { R } & \text { R }\end{array}$ \\
\hline $\begin{array}{l}\text { Discoaster pentaradiatus } \\
\text { Discoaster sp. } \\
\text { Prinsiaceae, small } \\
\text { Pseudoemiliania lacunosa } \\
\text { Reticulofenestra pseudoumbilica }\end{array}$ & $\left|\begin{array}{llllll}A & A & C & F & C & C \\
R & R & R & R & F & F\end{array}\right|$ & $\begin{array}{lllllllllllll} & & \text { R } & & & & \\
\text { C } & C & C & C & F & F & F\end{array}$ & $\mathrm{R}$ & \begin{tabular}{ll|}
$X$ & \\
$X$ & $X$ \\
$R$ & $C$ \\
$X$ & $C$ \\
\end{tabular} & $\begin{array}{lllllllll} & & & & & & & \\
& & \text { R } & & & & \text { X } \\
\text { A } & \text { A } & \text { A } & \text { A } & \text { A } & \text { A } & \text { A } & \text { A } \\
& & & & & & & \\
\text { A } & \text { A } & \text { A } & \text { A } & \text { A } & \text { A } & \text { A } & \text { A } \\
\end{array}$ & $\begin{array}{lllll}\text { A } & \text { A } & \text { A } & \text { A } & \text { A } \\
& & & & \\
\text { A } & \text { A } & \text { A } & \text { A } & \text { A } \\
\end{array}$ \\
\hline $\begin{array}{l}\text { Sphenolithus abies } \\
\text { S. neoabies } \\
\text { Thoracosphaera sp. }\end{array}$ & & $\mathrm{R}$ & & & $\begin{array}{lll}\mathrm{R} & \mathrm{R} & \\
& \mathrm{R} & \mathrm{R} \\
\end{array}$ & \\
\hline
\end{tabular}

Note: See Table 4A for explanation of symbols.

suggested by Martini (1971). The degree of biostratigraphic resolution obtainable using calcareous nannofossils is highest in the lower latitudes where diversity is high, and gradually decreases to the north and south with the decrease in diversity. The association of two authors having different experiences with southern and northern high-latitude calcareous nannofossils provided a valuable opportunity to consider the following:

1) How far south and north can the "tropical" zonations be used? It was noted by Perch-Nielsen (1972) that in the north Atlantic, the "tropical" zones were generally useful to almost $60^{\circ} \mathrm{N}$ in the Paleogene, while similar correlations in the Neogene became increasingly more difficult as the sediments became younger. Although the index species were usually present, they were often extremely rare. Biostratigraphy could be based mainly on nannoliths such as discoasters, sphenoliths, and ceratoliths. In the southern high-latitude sites drilled on Leg 29, the "tropical" zones could hardly be used in the Paleocene and early Eocene. By mid Eocene the marker species of families other than Coccolithaceae and Prinsiaceae began to disappear south of about $50^{\circ} \mathrm{S}$. Only a few low-ranging discoasters are present, and the Prinsiaceae (Reticulofenestra, Dictyococcites, Cyclicargolithus, Pseudoemiliania, Gephyrocapsa, and finally Emiliania) constitute the greatest part of the assemblage. This assemblage also includes Coccolithus pelagicus s.l., and occasional occurrences of warmer species as "visitors." Thus the "tropical" zones can be recognized farther north than south. This situation is easily explained by the effect of the warm Gulf
Stream on that portion of the northern Atlantic in which the sequences studied have been recovered.

2) Is there a difference in the relative levels of the first and/or last occurrences of different species in northern and southern high latitudes? Some examples of reversed events were observed. For example, the first occurrences of Reticulofenestra bisecta and Chiasmolithus oamaruensis change their relationship to each other. In Denmark and at Site 277, C. oamaruensis occurs before $R$. bisecta whereas in New Zealand $R$. bisecta appears before C. oamaruensis (Edwards, 1971). Details of this and eventual other "reversed" first occurrences will, however, have to await further, more detailed, investigation before they are understood. It is well known that, for example, Isthmolithus recurvus is not a "reliable" taxon in low latitudes. Also, Discoaster saipanensis, the last occurrence of which marks the Eocene-Oligocene boundary in low latitudes, is unreliable in high southern and northern latitudes. Such examples illustrate the uncertainties involved in the age assignments. They also demonstrate the idealistic nature of the assumption that first and last occurrences occur at the same time all over the world. Diachronous first and last appearances are far more frequent in the high southern and northern latitudes than in the "tropical" regions.

3) Are there species in one region that do not occur in other high latitude regions? No detailed survey has yet been attempted to find the complete assemblages of southern high latitudes for different stratigraphic levels. Such studies need well-preserved material and sufficient time to study it extensively under the electron micro- 
TABLE 5B - Continued



scope in order to find and examine the rare and very rare species. Generally it can be said that truly oceanic assemblages have, in both the southern and northern high latitudes, a lower diversity than assemblages known from shelf regions.

While many species seem to be common to both northern and southern high latitudes, some seem to be restricted to the northern latitudes and a very few to the southern latitudes. This certainly is partly due to the fact that far less studies have been made from the southern high latitudes and thus fewer species have been found. Selected species found only in the southern high latitudes are therefore of more interest here as if they occurred in the north they should have been found and described by now. In the Paleocene, we note the presence of the genus Hornibrookina in New Zealand and at DSDP Sites 206, 207, 208, and 277. Only one of the two species of this distinctive genus has so far been found in the north ( $H$. australis, in the Crimea, U.S.S.R.). In the Eocene we note the presence of Reticulofenestra hampdenensis from New Zealand and the Eocene of different sites of Legs 21 and 29. This species is very closely related to, and perhaps identical with, Dictyococcites onustus Perch-Nielsen, and Cribrocentrum foveolatum (Reinhardt). The new species described in this paper from the Oligocene of Site 277, Helicopontosphaera? subantarctica, is so large and easily recognizable in the light microscope that it should have been found earlier in the northern hemisphere, if it existed there. Apart from Hornibrookina teuriensis it might be the only really southern taxon found so far. The occurrence of the Ilselithina sp. in the Miocene is also noteworthy, and might be another indication of a coccolith with a restricted southern distribution. However, this small and delicate form might have been overlooked in other samples.

4) Is the fine structure of species the same in northern and southern high latitudes, or are there differences that exceed the usual species concept, but which cannot be distinguished using the light microscope? The fine structure of a limited number of species, mainly of the Paleocene to Oligocene of Site 277, has been studied with the scanning electron microscope (SEM) for comparison with the fine structure of calcareous nannofossils studied from DSDP Leg 12 (Perch-Nielsen, 1971a, b, and 1972 ) in the North Atlantic and from Denmark (PerchNielsen, 1971 b, c). So far the differences observed in the fine structure found in the same species from the northern and southern high latitudes can readily be attributed to differences in preservation. Solution and/or overgrowth have affected the fossils beyond recognition of possible differences in their structure if they ever existed.

\section{SYSTEMATIC PALEONTOLOGY}

No attempt has been made in this report to update the names of calcareous nannofossils listed on the tables or plates. From this study it was evident that the members of the Prinsiaceae family will have to be studied very closely with both the light microscope and the SEM if a reliable and relatively finely subdivided high-latitude zonation is to be established. In the following, three new species from the late Paleocene, early Oligocene, and early Miocene, respectively, are described.

\section{Genus ERICSONIA Black 1964}

Ericsonia tasmaniae n.sp.

(Plate 20, Figures 5-12)

Holotype: Plate 20, Figure 5; distal view.

Paratype: Plate 20, Figure 11; proximal view. 
TABLE 5C

Calcareous Nannofossil Distribution, Site 278

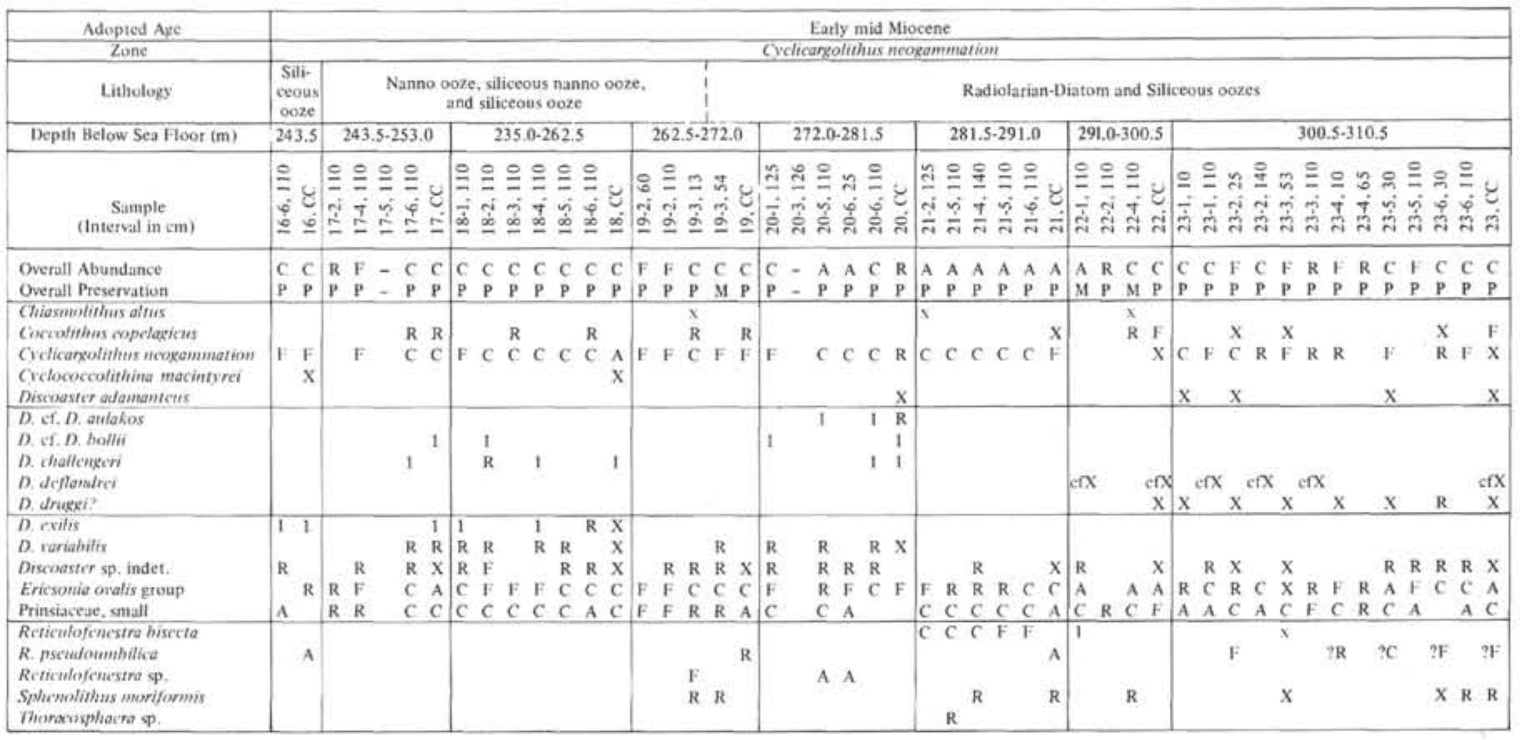

Note: See Table $4 \Lambda$ for explanation of ssmbols.

TABLE 5C - Continued

\begin{tabular}{|c|c|c|c|c|c|}
\hline Adopted Age & \multirow{2}{*}{\multicolumn{2}{|c|}{$\begin{array}{l}\text { Early mid Miocene } \\
\text { Cychicargolithus ncogammation }\end{array}$}} & \multicolumn{3}{|c|}{ Early Miocene } \\
\hline Zone & & & & iscoaster deflandrel & \\
\hline Lithology & \multicolumn{5}{|c|}{ Radiolarian-Diatom and Siliceous oozes } \\
\hline Depth Below Sea Floot (m) & $310.5 \cdot 319.5$ & $319.5-329.0$ & $329.0-338.5$ & $338.5-348.0$ & $348.0-357.5$ \\
\hline $\begin{array}{c}\text { Sample } \\
\text { (Interval in } \mathrm{cm} \text { ) }\end{array}$ & 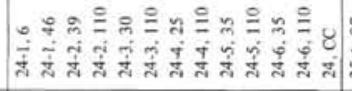 & 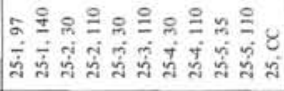 & 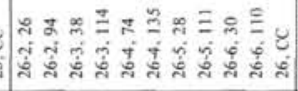 & 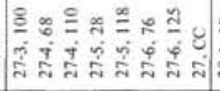 & 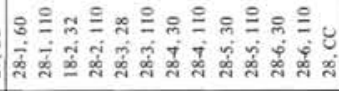 \\
\hline $\begin{array}{l}\text { Overall Abundance } \\
\text { Owerall Preservation }\end{array}$ & $\begin{array}{lllllllllllll}C & C & C & C & C & C & C & C & C & F & R & F & R \\
P & P & P & P & P & P & P & P & P & P & P & P & P\end{array}$ & $\begin{array}{lllllllllll}C & F & F & C & F & R & C & F & R & F & C \\
P & P & P & P & P & P & P & P & P & P & P \\
\end{array}$ & $\begin{array}{lllllllllll}C & F & C & C & F & R & C & F & C & R & C \\
P & P & P & P & P & P & P & P & P & P & P \\
P\end{array}$ & 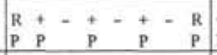 & 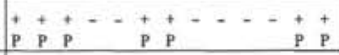 \\
\hline  & $\begin{array}{|lllllllllll|}R & R & R & R & & R & F & & & & R \\
X & F & X & F & R & F & & R & R & R & X \\
& X & & & & & & \\
\end{array}$ & \begin{tabular}{|lllllllllll}
$R$ & $R$ & $X$ & $R$ & $R$ & $R$ & $F$ & $R$ & $R$ & $X$ \\
$R$ & $R$ & $R$ & $R$ & $X$ & $R$ & $R$ & $F$ & & $F$ & $R$ \\
$X$ & $X$ & & & & & & \\
$X$
\end{tabular} & C F F F F R C C C & c & \\
\hline  & $\bar{R}_{\mathrm{R}}^{-c f \mathrm{X}} \quad \overline{\mathrm{R}}-\bar{X}^{c f \mathrm{X}-c f \mathrm{X}-}$ & $x R$ & $\begin{array}{llllll}x & x & x & x & x & x \\
\end{array}$ & & \\
\hline $\begin{array}{l}\text { D. exillis } \\
\text { D. variahilis } \\
\text { Discrester sp, indet. } \\
\text { Ericsomia oralis proup } \\
\text { Prinxiaceae, small } \\
\end{array}$ &  & 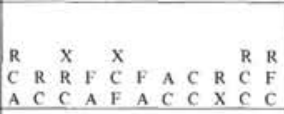 & $\begin{array}{lllllllllll}C & F & C & C & F & R & C & C & C & R & C \\
C & C & C & C & C & R & A & A & A & R & A\end{array}$ & $\begin{array}{l}R \\
R\end{array}$ & R \\
\hline 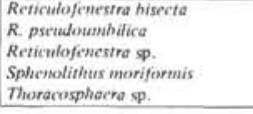 & $\mathrm{R} \times \mathrm{X} \quad \mathrm{X} \mathrm{R} \times$ & $\mathrm{R} X$ & $\mathrm{x}$ & R R & $\begin{array}{ll}\mathrm{X} & \mathrm{R}\end{array}$ \\
\hline
\end{tabular}

Diagnosis: Ericsonia with a perforated central area surrounded directly by the distal shield in distal view.

Description: The distal shield, which is larger than the proximal shield, consists of about 30 to 40 elements lying side by side. No other elements are inserted between them, and the elements spanning the central area. These are platey on the distal side, and perforated by few to common small, more or less well defined holes. The proximal shield consists, as usual of Ericsonia, of two cycles of elements.

Remarks: E. tasmaniae is very similar to the mainly late Eocene and Oligocene Ericsonia fenestrata group. However, E. fenestrata is usually larger and shows an additional ring of elements (in distal view) between the distal shield, and the central area.

Occurrence: The holotype and paratype of E. tasmaniae were obtained from the early Miocene of Site 282, west of Tasmania. This species seems to be quite common in the high-latitude Pacific Miocene. E. tasmaniae is the youngest perforate Ericsonia known to date. Due to its minute size, the perforations are difficult to dis- tinguish in the light microscope, where it more closely resembles a very small Chiasmolithus or Cruciplacolithus than a perforate Ericsonia.

Genus HELICOPONTOSPHAERA Hay and Mohler 1967

Helicopontosphaera? subantarctica n. sp.

(Plate 14, Figures 1-7; Plate 15, Figures 1-3, 7, 8)

Holotype: Plate 15, Figures 3 and 8; distal view.

Paratype: Plate 15, Figure 7; proximal view.

Diagnosis: An essentially elliptical proximal shield is connected by a "tubus" to a usually very asymmetrical distal shield forming a flange. Central area elliptical and (?) open.

Description: By far the most conspicuous feature of this new species is its (often) enormous flange on the distal side of the coccolith. It consists of elements which are oriented almost radially but which converge towards each other where the flange is largest. The flange includes one length of the coccolith, while the opposite side is built by a 
TABLE 5D

Calcareous Nannofossil Distribution, Site 278

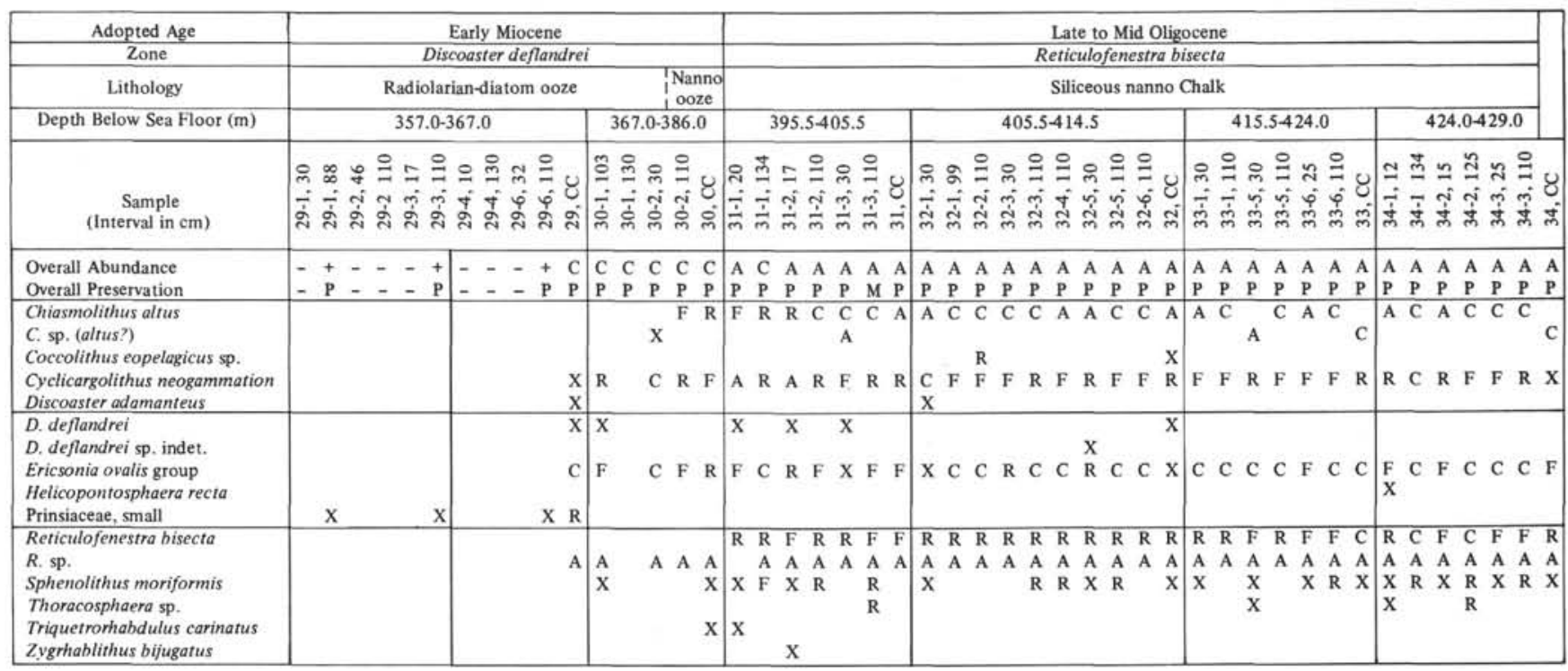

Note: See Table 4A for explanation of symbols.

TABLE 6

Calcareous Nannofossil Distribution, Site 279

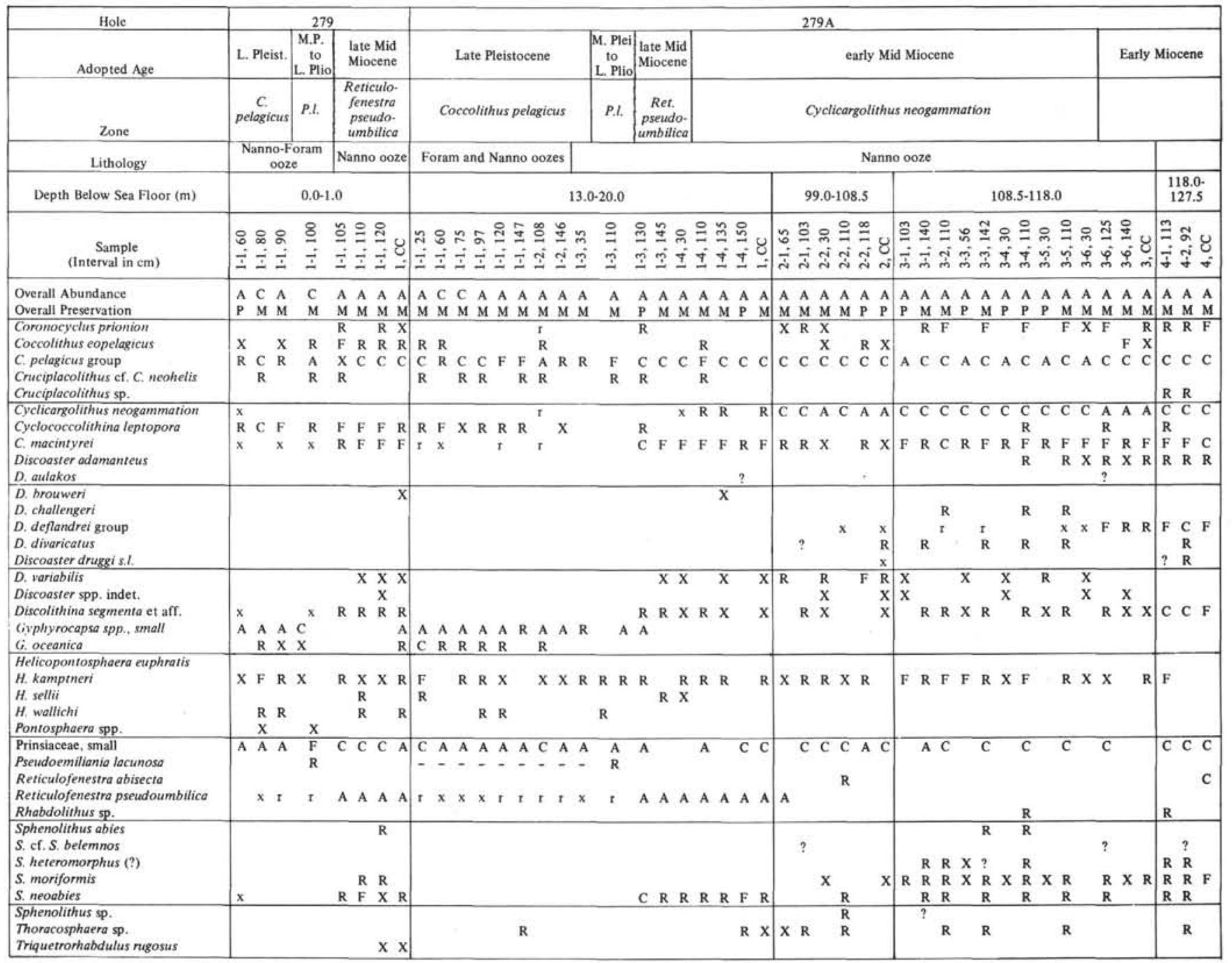

Note: See Table 4A for explanation of symbols. 
TABLE 6 - Continued

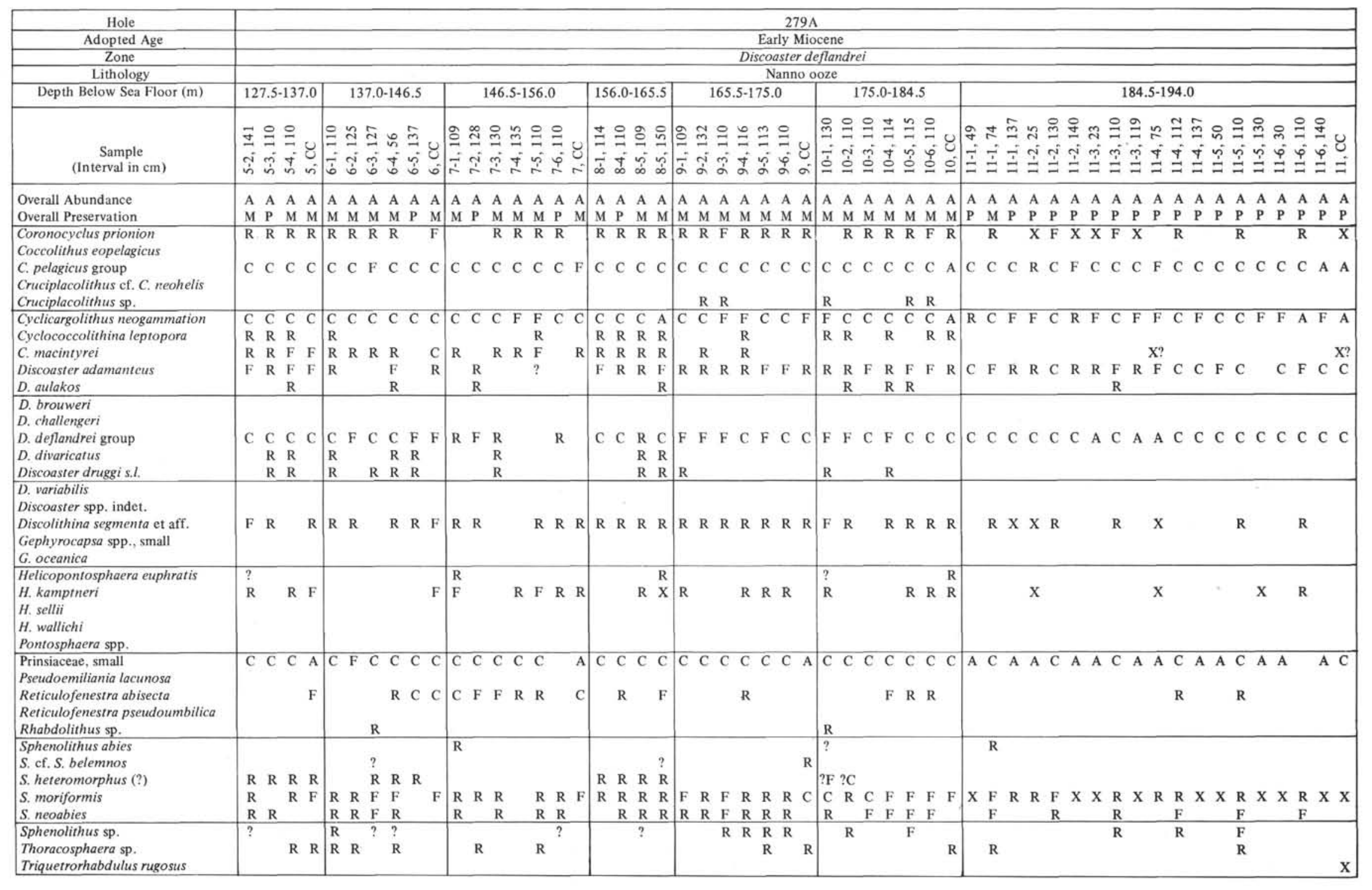


normal distal shield. A layer of nearly vertical elements forms a wall between the distal shield and the central area on the distal side of the coccolith. The proximal shield consists of radial oriented elements. A suture is visible where the proximal shield ends and the bend to the vertical "tubus" begins. The latter is built by a continuation of the elements of the proximal shield towards the central area. Thus the pattern known from the forms of Discolithina/Pontosphaera and Helicopontosphaera, with a proximal side consisting of radial elements and a distal side with concentric elements, seems to be repeated in $H$ ? subantarctica. In this form the distal side of the central area, when present, also is found to consist of concentric elements. In none of the many specimens found of the new species was the central area completely covered or spanned by a bridge.

Remarks: Some doubts exist as to the generic position of this new species. It seems most likely, however, that it evolved from a Helicopontosphaera and is therefore tentatively placed in this genus. Apart from the asymmetrical flange, this species has nothing in common with the Late Cretaceous genus Kamptnerius. The species of Pontosphaera and Discolithina have walls with an elliptical outline and do not develop a proximal shield or comparable structure.

Occurrence: $H$ ? subantarctica was found in the early Oligocene of Site 277 on the Campbell Plateau, where it is common. The finding of such an easily recognizable and large new species in the early Oligocene, which has been closely studied in many widely separated parts of the world, is surprising. It is concluded that the species probably has a rather restricted distribution.

\section{Genus HORNIBROOKINA Edwards 1973}

Hornibrookina australis n. sp.

(Plate 2, Figures 1-3, 6, 9, 12; Plate 5, Figures 6, 9, 12)

Hornibrookina sp., in Edwards, 1973a, p. 77, fig. 82.

Hornibrookina n. sp., in Edwards, 1973b, pl. 9, fig. 1-3.

Holotype: Plate 2, Figure 9; distal view.

Paratype: Plate 2, Figure 6; proximal view.

Diagnosis: Hornibrookina with a slightly elongate to rhomboedrical outline and relatively narrow proximal and distal shields forming a convexly arched coccolith.

Description: The body has a somewhat asymmetrical outline (elongate to rhomboedrical) and is convexly arched. The distal shield consists of about 20 elements lying side by side and continuing into the large central area as parallel, elongate bars. The proximal shield is much smaller than the distal shield and very narrow. Its elements continue to the distal side, where they form the wall around the central area, overlapping each other considerably.

Remarks: $H$. australis differs from $H$. teuriensis Edwards by its more irregular outline, smaller size, and narrower shields. $H$. australis is remarkably well preserved in samples where most of the other coccoliths show signs of solution and/or overgrowth.

Occurrence: $H$. australis was first found in the Late Paleocene of New Zealand and subsequently in the late Paleocene of DSDP 207A on Lord Howe Rise (Edwards, 1973a, b). During Leg 29 this species was observed in the late Paleocene of DSDP Site 277 on the Campbell Plateau, where it is "few to common". It has also been found in the late Paleocene of the Crimea, U.S.S.R. (Perch-Nielsen, unpublished).

\section{ACKNOWLEDGMENTS}

The Scanning Electron Micrographs were made at the Institute for Historical Geology and Palaeontology, Copenhagen. The participation of KPN in Leg 29 was made possible by a grant from the Danish National Science Foundation. ARE acknowledges the support given by the New Zealand Department of Scientific and Industrial Research and by N. de B. Hornibrook of the New Zealand Geological Survey. Both authors thank our shipboard colleagues for many useful dis- cussions. Finally we wish to state our appreciation of the assistance freely given by the shipboard personnel, particularly Mrs. P. Paluso and Mrs. S. Thompson.

\section{REFERENCES}

Berggren, W. A., 1972. Cenozoic Time-Scale: some implications for regional geology and paleobiogeography: Lethaia, v. 5, p. 195-215.

Bukry, D., 1973. Coccolith and silicoflagellate stratigraphy, Tasman Sea and Southwestern Pacific Ocean, Deep Sea Drilling Project Leg 21. In Burns, R. E., Andrews, J. E., et al., Initial Reports of the Deep Sea Drilling Project, Volume 21: Washington (U.S. Government Printing Office), p. 885-893.

Edwards, A. R., 1968. The calcareous nannoplankton evidence for New Zealand Tertiary marine climate: Tuatara, v. 16(1), p. 26-31.

Edwards, A. R., 1971. A calcareous nanno-plankton zonation of the New Zealand Paleogene. In Farinacci, A. (Ed.), Plankt. Conf. 2nd, Roma, 1970, Proc. (Tecnoscienza), v. I, p. $381-420$.

Edwards, A. R., 1973a. Key species of New Zealand calcareous nannofossils: New Zealand J. Geol. Geophys., v. 16 , p. $68-89$.

Edwards, A. R., 1973b. Calcareous nannofossils from the southwest Pacific, Deep Sea Drilling Project, Leg 21. In Burns, R. E., Andrews, J. E., et al., Initial Reports of the Deep Sea Drilling Project, Volume 21: Washington (U.S. Government Printing Office), p. 641-691.

Edwards, A. R., 1973c. Southwest Pacific regional unconformities encountered during Leg 21. In Burns, R. E., Andrews, J. E., et al., Initial Reports of the Deep Sea Drilling Project, Volume 21: Washington (U.S. Government Printing Office), p. 701-720.

Hornibrook, N. de B., 1971. New Zealand Tertiary climate: New Zealand Geol. Surv. Rep. 47, p. 1-19.

Kennett, J. P. and Watkins, N. D., 1972. The biostratigraphic, climatic and paleo-magnetic record of late Miocene to early Pleisto-cene sediment in New Zealand: Internatl. Geol. Congr., 24, Montreal, p. 538 (Abstracts).

Martini, E., 1971. Standard Tertiary and Quaternary calcareous nannoplankton zonation: In Farinacci, A. (Ed.), Plankt. Conf. 2nd, Roma, 1970, Proc. (Tecnoscienza), v. II, p. 739-785.

Perch-Nielsen, K., 1971a. Einige neue Coccolithen aus dem Paleozän der Bucht von Biskaya: Denmark Geol. Soc. Bull. 20, p. $347-361$.

1971b. Neue Coccolithen aus dem Paelozän von Dänemark, der Bucht von Biskaya und dem Eozän der Labrador See: Denmark Geol. Soc. Bull. 21, p. 51-66. 1971c. Elektronenmikroskopische Untersuchungen an Coccolithen und verwandten Formen aus dem Eozän von Dänemark: Det Kogelige Danske Videnskabernes Selskab Biologiske Skrifter, v. 18(3), p. 1-76. 1972. Remarks on Late Cretaceous to Pleistocene Coccoliths from the North Atlantic: In Laughton, A. S., Berggren, W. A., et al., Initial Reports of the Deep Sea Drilling Project, Volume 12: Washington (U.S. Government Printing Office), p. 1003-1069. 
TABLE 7

Calcareous Nannofossil Distribution, Site 280

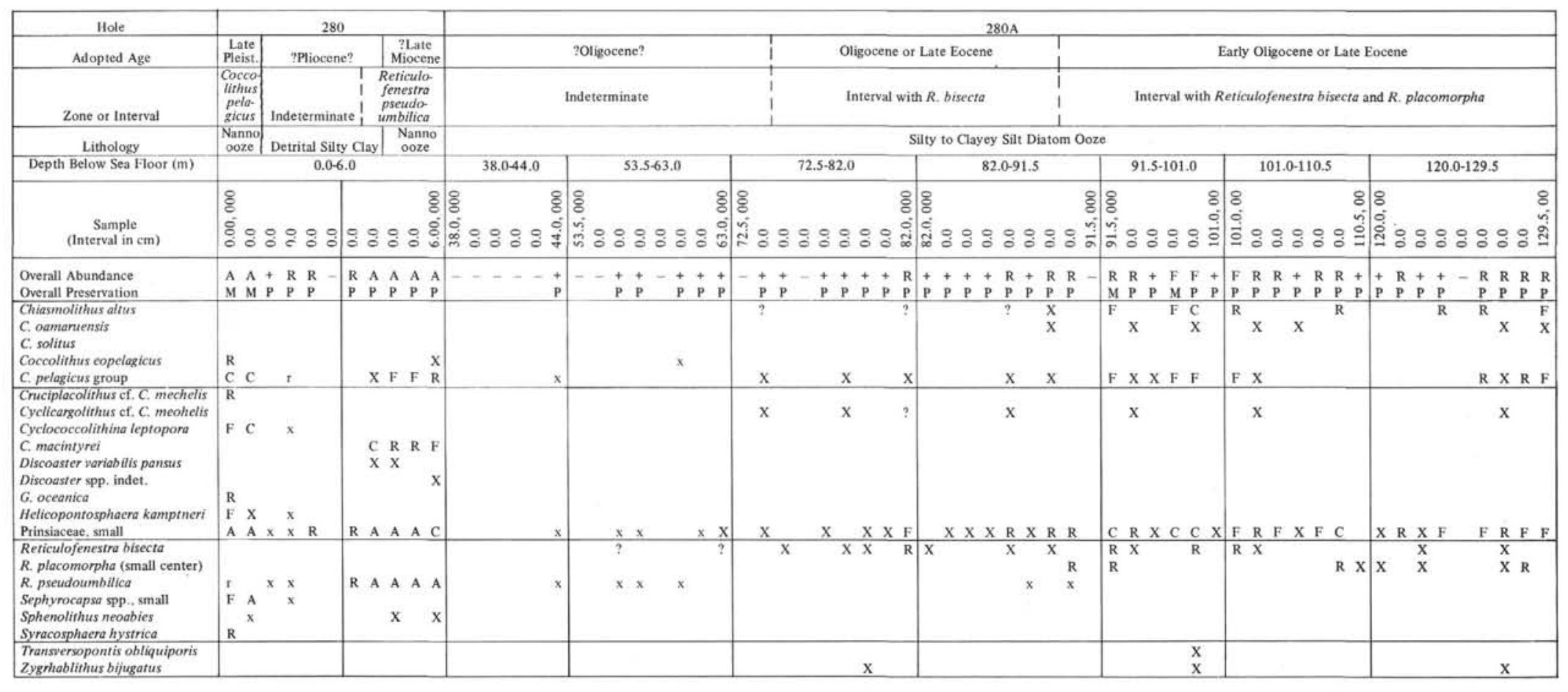

Note: See Table $4 \mathrm{~A}$ for explanation of symbols. 
TABLE 7 - Continued

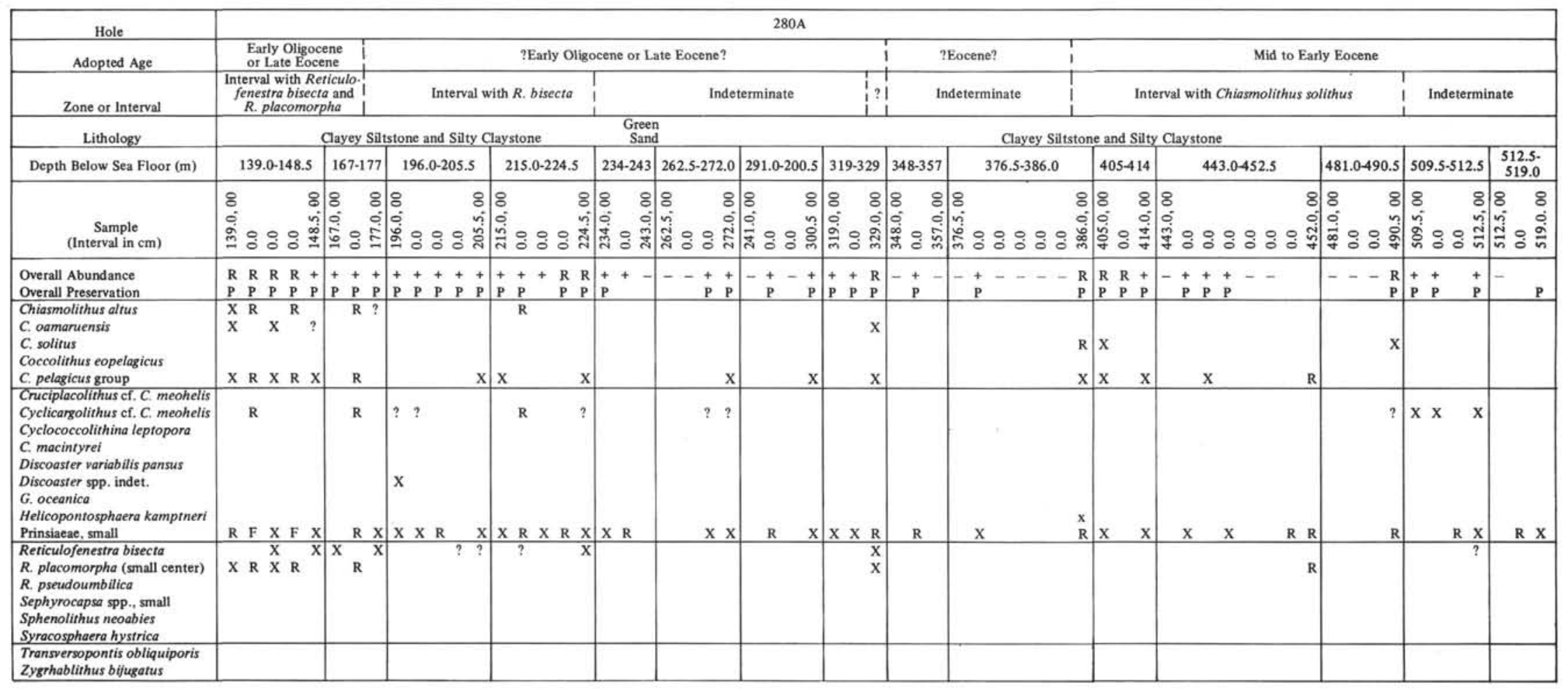


TABLE 8A

Calcareous Nannofossil Distribution, Site 281

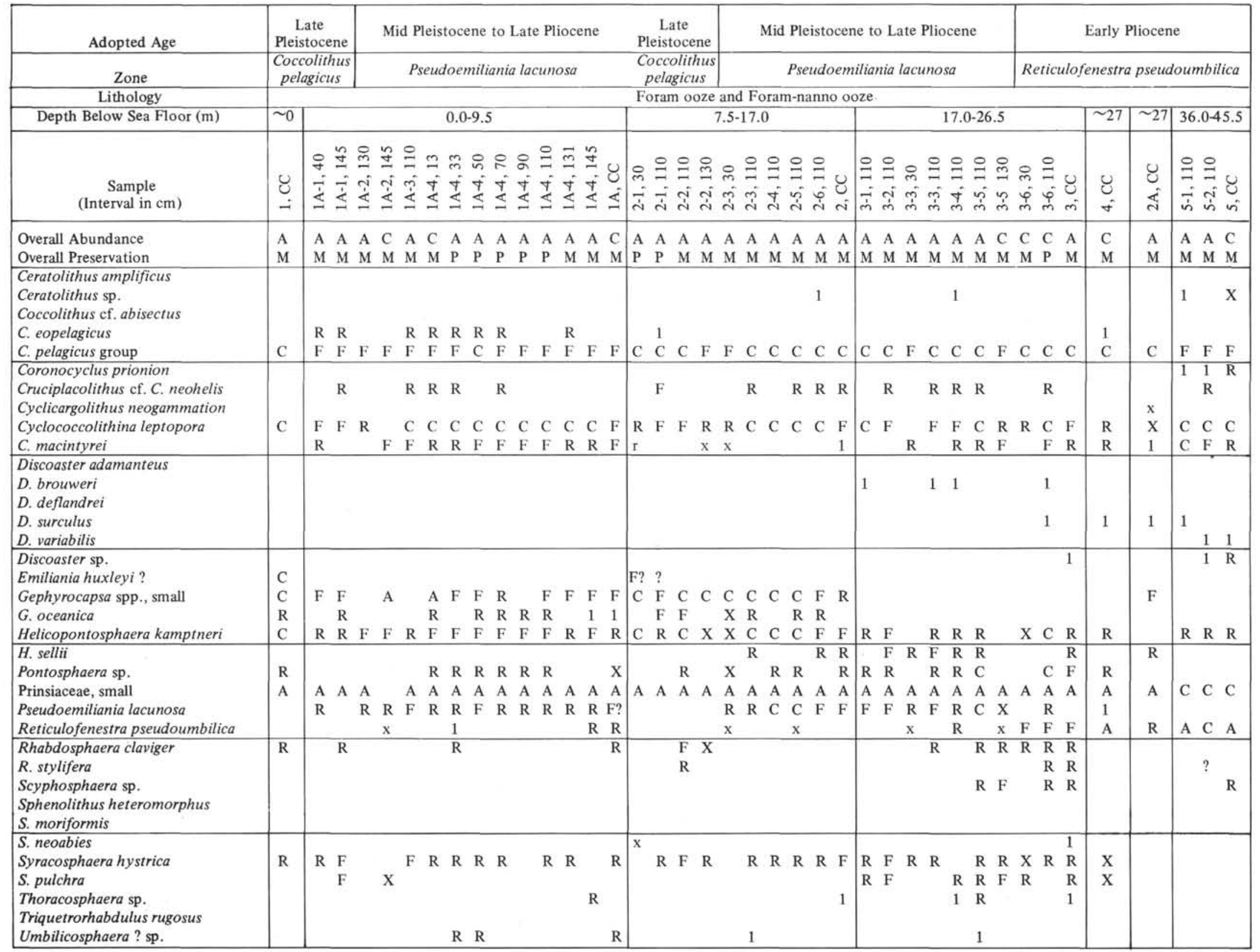

Note: See Table 4A for explanation of symbols. 
TABLE 8A - Continued




TABLE 8B

Calcareous Nannofossil Distribution, Site 281

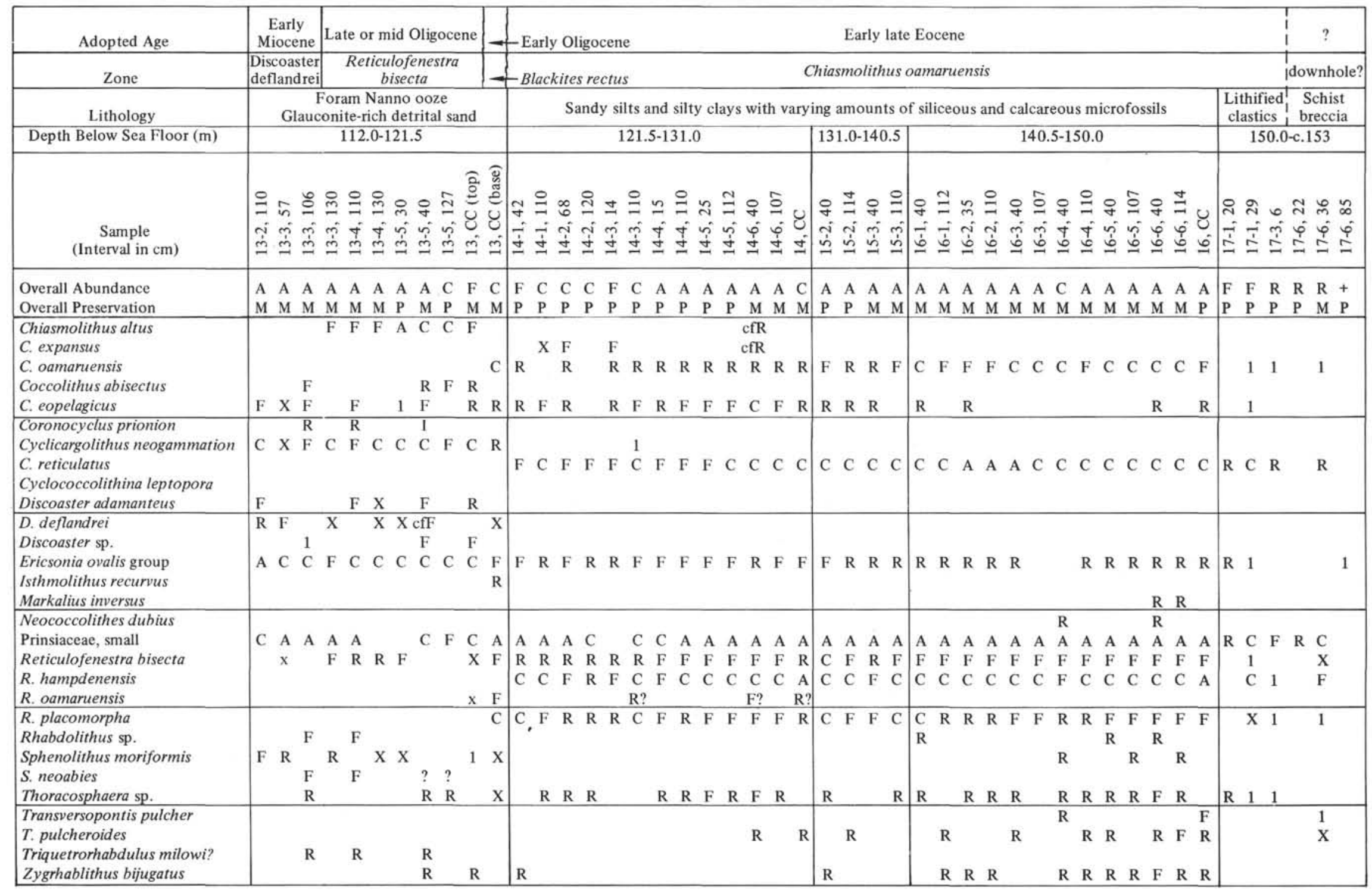

Note: See Table 4A for explanation of symbols. 
TABLE 9A

Calcareous Nannofossil Distribution, Site 282

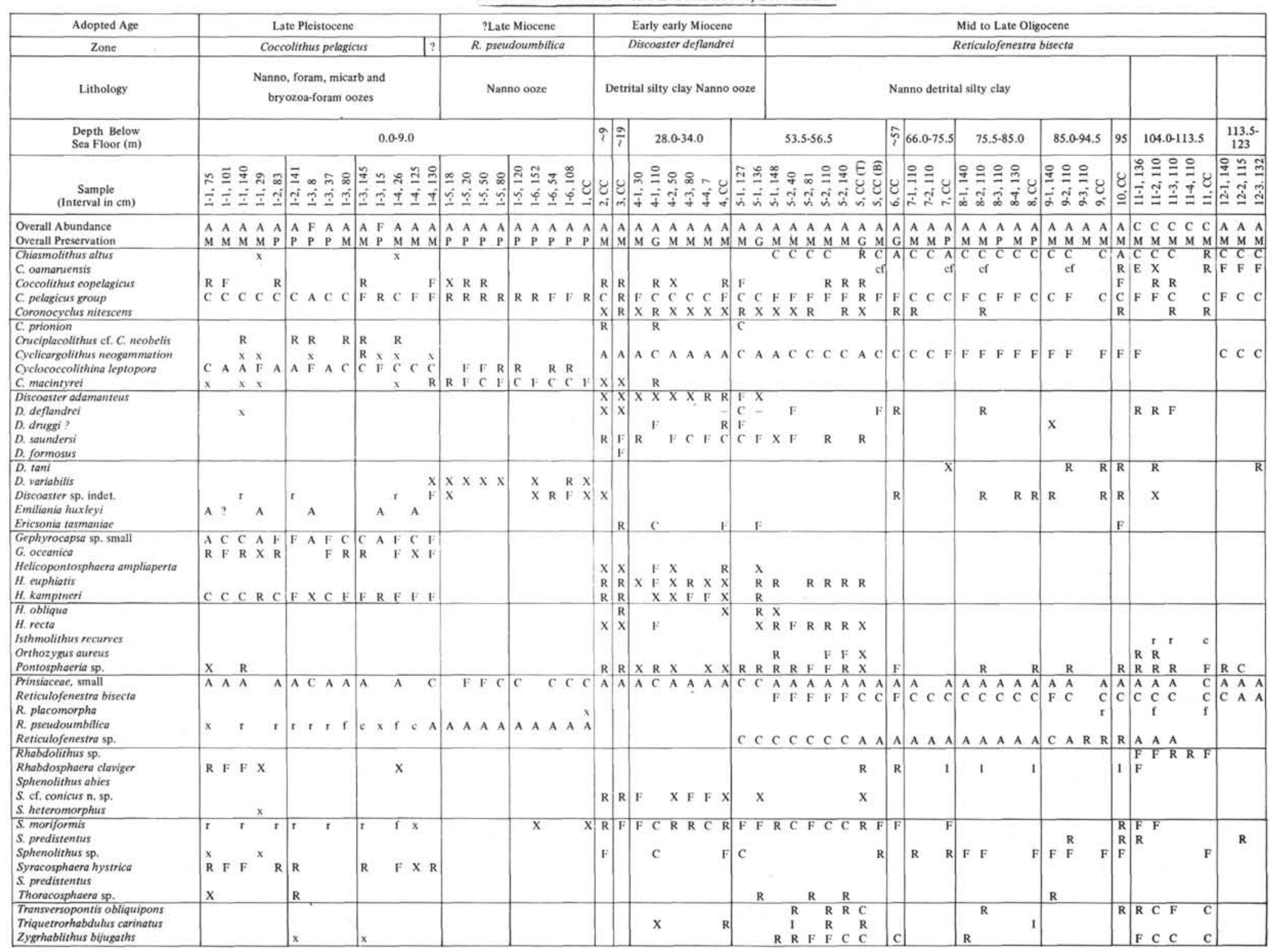


TABLE 9B

Calcareous Nannofossil Distribution, Site 282

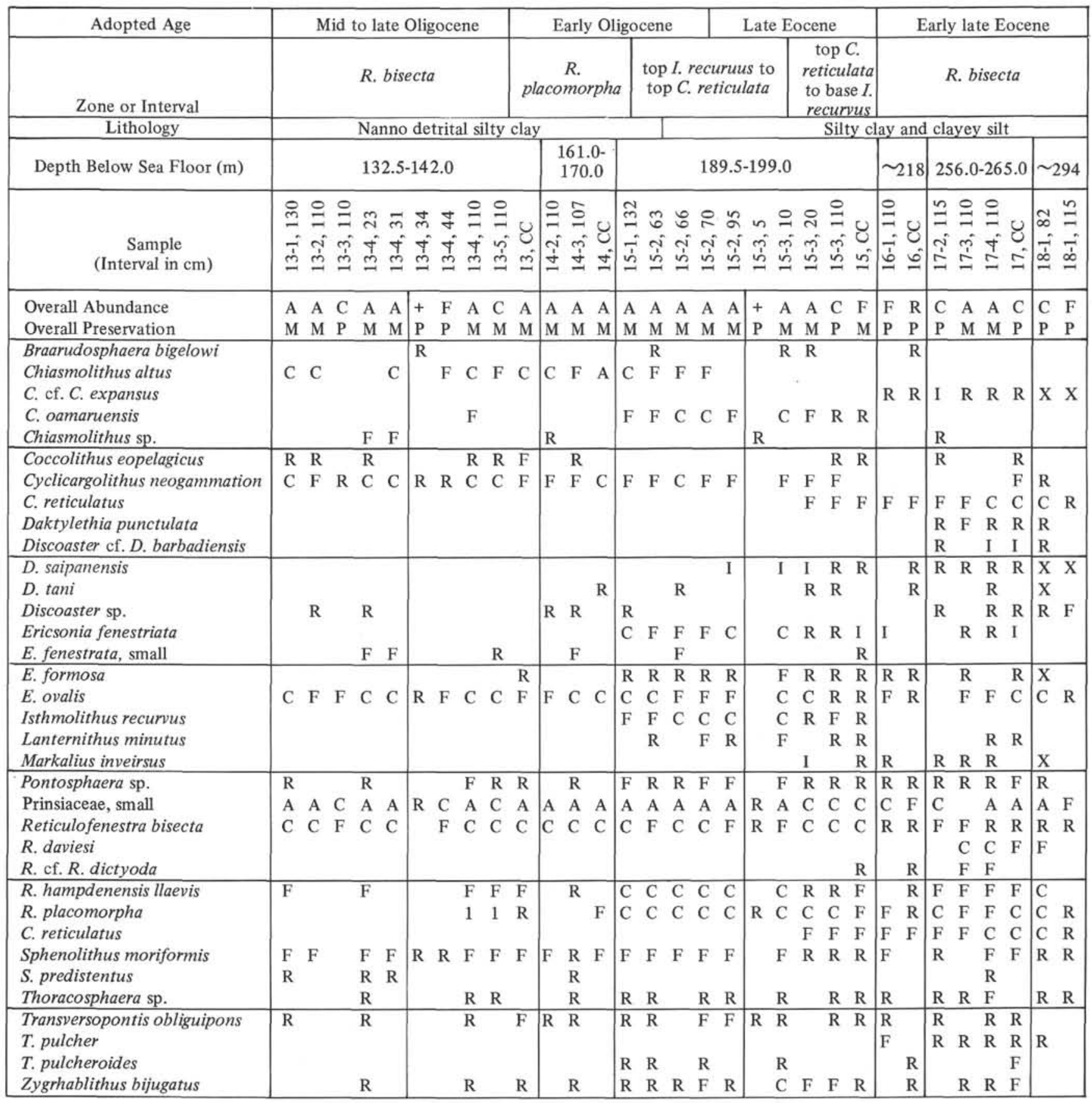

Note: See Table 4A for explanation of symbols. 
TABLE 10

Calcareous Nannofossil Distribution, Site 283

\begin{tabular}{|c|c|c|c|c|c|c|c|c|c|c|c|c|}
\hline \multirow{3}{*}{$\begin{array}{c}\text { Adopted Age } \\
\text { Zone } \\
\text { Lithology }\end{array}$} & \multicolumn{2}{|c|}{$\begin{array}{l}\text { Mid to early I } \\
\text { Pleistocene }\end{array}$} & \multicolumn{3}{|c|}{$\frac{1}{1}$ Late Pliocene } & \multicolumn{3}{|c|}{ ?Late Eocene? } & \multicolumn{2}{|c|}{ Early late Eocene } & \multicolumn{2}{|c|}{ Eocene or older } \\
\hline & \multicolumn{2}{|c|}{$\begin{array}{l}\text { Pseudoemilian } \\
\text { lacumosa }\end{array}$} & \multicolumn{3}{|c|}{ Indeterminate } & & & & \multicolumn{2}{|r|}{ Chiasmolithus oamaruensis } & \multicolumn{2}{|c|}{ Indeterminate } \\
\hline & \multicolumn{3}{|c|}{$\begin{array}{l}\text { Manganese Nodules } \\
\text { Zeolitic clay }\end{array}$} & ay (Unit 1A) & $\left\{\begin{array}{c}\text { Silty zeolitic clay } \\
\text { (Unit 1B) }\end{array}\right\}$ & \multicolumn{5}{|c|}{ Diatom ooze (Unit 2) } & \multicolumn{2}{|c|}{ Silty clay (Unit 3 ) } \\
\hline Depth Below Sea Floor $(\mathrm{m})$ & 1.5 & $0.5^{*}$ & $11.0-20.5$ & $10.0-$ & -19.5 & 29.0 & 57.5 & $86.0-95.5$ & $124.0-133.5$ & $152.5-162.0$ & $190.5-200.0$ & $219.0-228.5$ \\
\hline $\begin{array}{c}\text { Sample } \\
\text { (Interval in } \mathrm{cm} \text { ) }\end{array}$ & $\begin{array}{l}8 \\
\vdots \\
-\end{array}$ & $\begin{array}{l}0 \\
-\end{array}$ & 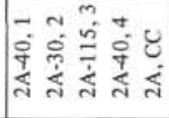 & 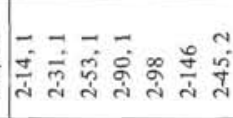 & 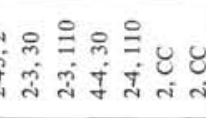 & S. & $\begin{array}{l}8 \\
\dot{+}\end{array}$ & 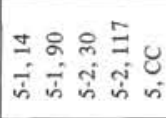 & 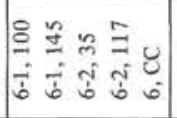 & 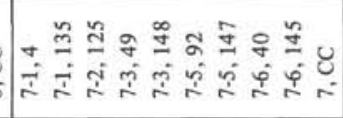 & 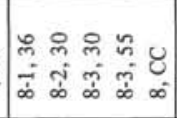 & 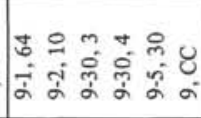 \\
\hline $\begin{array}{l}\text { Overall Abundance } \\
\text { Overall Preservation }\end{array}$ & $\begin{array}{l}\text { C } \\
\text { P }\end{array}$ & $\begin{array}{l}\mathrm{C} \\
\mathrm{P}\end{array}$ & $\begin{array}{llll}\mathrm{A} & + & + & + \\
\mathrm{P} & & \mathrm{P} & \mathrm{P}\end{array}$ & $\cdots+{ }_{\mathrm{P}}^{+}$ & $\cdots{ }_{\mathrm{P}}^{+} \mathrm{P}^{+}$ & $\cdot$ & $\begin{array}{l}+ \\
\mathrm{P}\end{array}$ & $\because+\begin{array}{r}+ \\
\mathrm{P}\end{array}$ & $\left|\begin{array}{lllll}\mathrm{C} & \mathrm{C} & \mathrm{C} & \mathrm{C} & \mathrm{C} \\
\mathrm{P} & \mathrm{P} & \mathrm{P} & \mathrm{P} & \mathrm{P}\end{array}\right|$ & $\begin{array}{llllllllll}C & A & C & C & C & C & C & C & C & C \\
P & \text { N } & P & P & P & P & P & P & P & P\end{array}$ & $\cdots \cdots \frac{\mathrm{X}}{\mathrm{P}}$ & $\cdots \cdots{ }_{\mathrm{P}}^{\mathrm{X}}$ \\
\hline $\begin{array}{l}\text { Chiasmolithus altus } \\
\text { C. oamaruensis } \\
\text { Coccolithus pelagicus } \\
\text { Cyclicargolithus reticulatus } \\
\text { Cycloccolithina leptopora }\end{array}$ & $\begin{array}{l}x \\
x \\
c\end{array}$ & F & 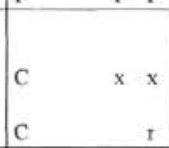 & $e_{0}$ & $x^{2}=1$ & & & & $\left|\begin{array}{lllll}F & F & R & F & R \\
A & C & C & C & C\end{array}\right|$ & $\begin{array}{llllllllll}R & F & R & X & F & F & F & R & R & F \\
C & F & A & C & F & A & F & C & F & X\end{array}$ & 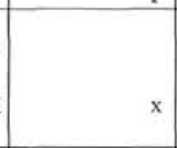 & \\
\hline $\begin{array}{l}\text { C. macintyrei } \\
\text { Dactylethra punctulata } \\
\text { Discoaster asymmetricus } \\
\text { D. pentaradiatus } \\
\text { D. saipanensis }\end{array}$ & & & $\begin{array}{l}F \\
x \\
X\end{array}$ & & & & & & $\mathrm{x}$ & $x \times x \quad x \quad x \quad x \quad x$ & & \\
\hline $\begin{array}{l}\text { D. tani nodifer } \\
\text { Discolithina multipora } \\
\text { D. pulcheroides } \\
\text { Ericsonia ovalis } \\
\text { Gephyrocapsa spp., small }\end{array}$ & A & $\mathrm{R}$ & - & & $\mathrm{x}$ & & $x$ & & $\mathrm{~F} X$ & 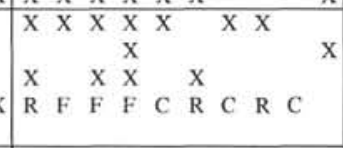 & $\mathrm{x}$ & $\mathrm{x}$ \\
\hline $\begin{array}{l}\text { G. oceanica } \\
\text { Helicopontosphaera kamptneri } \\
\text { Markalius inversus } \\
\text { Neococcolithes dubius } \\
\text { N. mimutus }\end{array}$ & $\mathrm{R}$ & $\begin{array}{l}x \\
x\end{array}$ & $\bar{R}$ & & & & & & & $x^{x}$ & & \\
\hline $\begin{array}{l}\text { Pontosphaera multipora } \\
\text { Prinsiaceie, small } \\
\text { Pseudoemiliania lacunosa } \\
\text { Reticulofenestra bisecta } \\
\text { R. dariesi }\end{array}$ & $\begin{array}{l}\mathrm{A} \\
\mathrm{R} \\
\mathrm{x}\end{array}$ & $\mathrm{A}$ & $\begin{array}{l}\mathrm{A} \\
\mathrm{R}\end{array}$ & & $\mathrm{x}$ & & $x$ & $\mathrm{R} X$ & $\mid \begin{array}{ccccc}C & C & F & C & C \\
R & & F\end{array}$ & 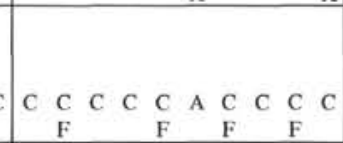 & $\mathrm{x}$ & \\
\hline $\begin{array}{l}\text { Reticulofenestra hampdenensis } \\
\text { Reticulofenestra sp. cf. minutulus } \\
\text { R. placomorpha } \\
\text { Reticulofenestra, small } \\
\text { Rhabdolithus sp. }\end{array}$ & A & c & C & $\mathrm{x}$ & $\mathrm{x}$ & & $\mathrm{x}$ & $\begin{array}{ll}R & R \\
F & F\end{array}$ & $\left|\begin{array}{lllll}\mathrm{A} & & \mathrm{X} & & \mathrm{R} \\
\mathrm{C} & \mathrm{C} & \mathrm{F} & \mathrm{C} & \mathrm{C} \\
\mathrm{A} & \mathrm{A} & \mathrm{A} & \mathrm{A} & \mathrm{A} \\
\mathrm{X} & \mathrm{X} & & \mathrm{X} & \mathrm{X}\end{array}\right|$ & 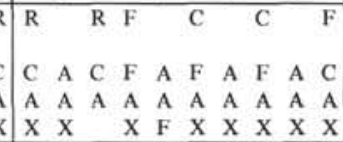 & $\begin{array}{l}\mathrm{x} \\
\mathrm{r}\end{array}$ & \\
\hline $\begin{array}{l}\text { Sphenolithus sp. } \\
\text { Thoracosphaera sp. }\end{array}$ & & & & & & & & & $\begin{array}{lll}x & x & x\end{array}$ & $\begin{array}{lllllll} & x_{R} & X & X & X & X & \end{array}$ & & \\
\hline
\end{tabular}

Note: See Table 4A for explanation of symbols. 


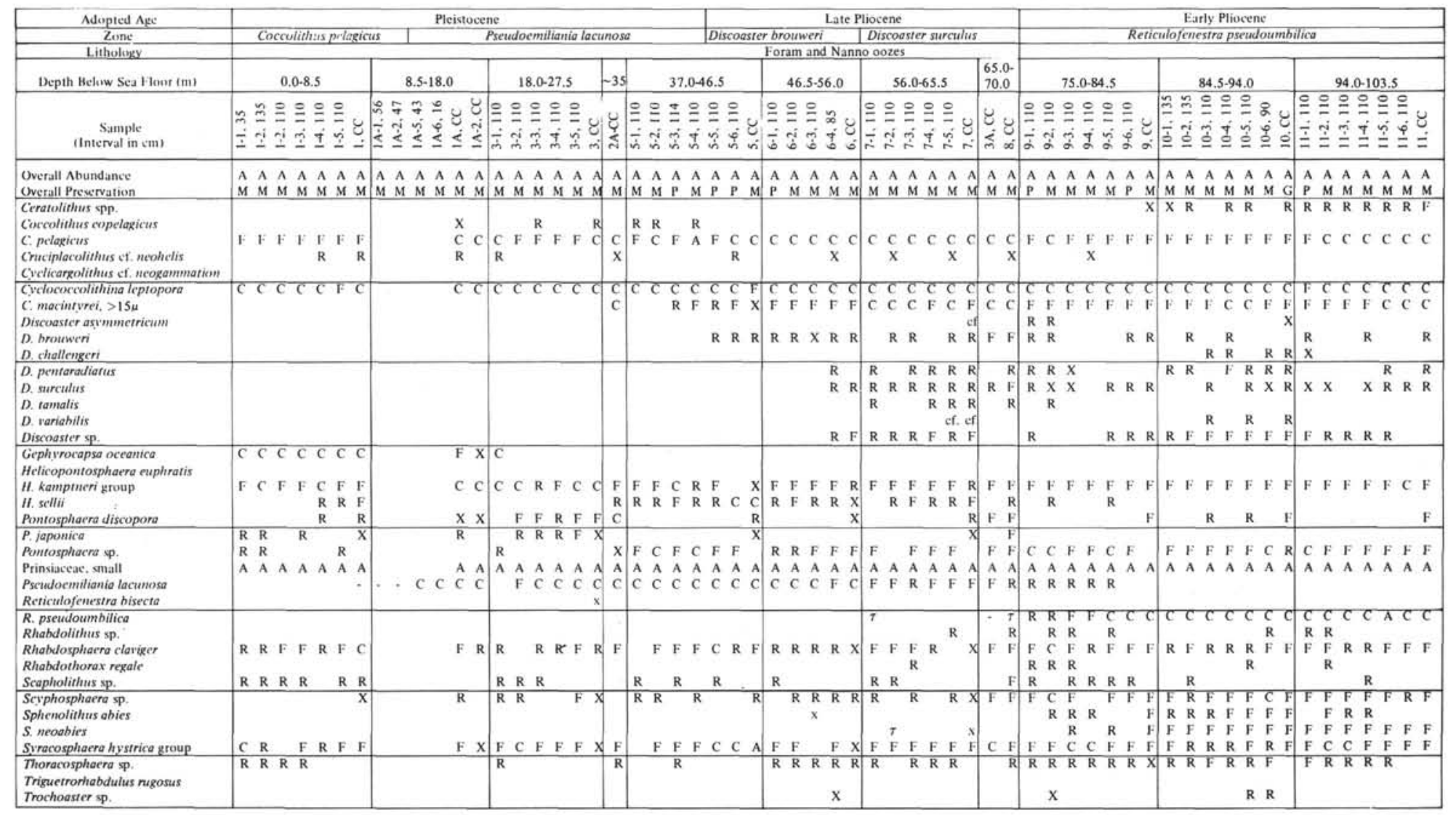


TABLE 11 - Continued

\begin{tabular}{|c|c|c|c|c|c|c|c|c|c|c|c|}
\hline Adopted $A_{B:}$ & \multicolumn{2}{|c|}{ Earlv Pliocene } & \multirow{2}{*}{\multicolumn{8}{|c|}{ Undifferentiated early Pliocene to late Miocene }} & Late Miocene \\
\hline Zone & \multirow{2}{*}{\multicolumn{11}{|c|}{$\begin{array}{l}\text { Reticulofenestra pseudoumbilica } \\
\text { Foram and Nanno oozes }\end{array}$}} \\
\hline Lithology & & & & & & & & & & & \\
\hline 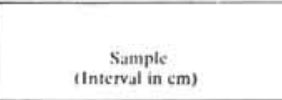 & 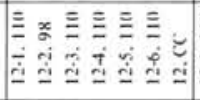 & 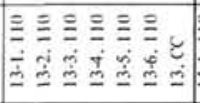 & 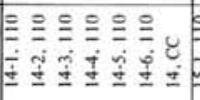 & 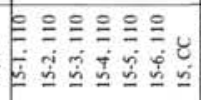 & 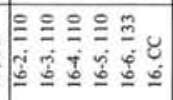 & 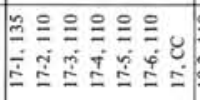 & 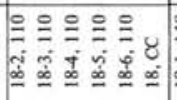 & 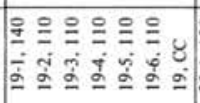 & 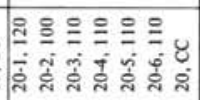 & 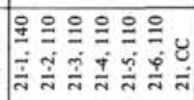 & 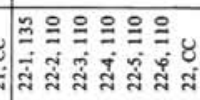 \\
\hline $\begin{array}{l}\text { efrall Abundance } \\
\text { ercill Pretervativen }\end{array}$ & $\hat{Y} \hat{M} \hat{M} \hat{M} \hat{M} \hat{M} \hat{M}$ & $\begin{array}{lllllll}A & A & A & A & A & A & A \\
M & M & M & P & M & M & 0\end{array}$ & A & $A$ A A $A$ A & $A$ A $A$ A A A & 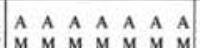 & $A$ A A & 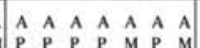 & $A \hat{A} A \hat{A} A \hat{P}$ & ${ }_{\mathrm{P}}^{\mathrm{A}} \hat{\mathrm{A}} \mathrm{P} \hat{\mathrm{P}} \mathrm{A} \hat{\mathrm{p}} \mathrm{A}$ & 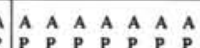 \\
\hline 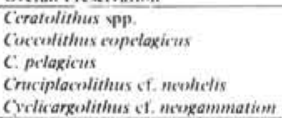 & {$\left[\begin{array}{lllllll}R & R & R & R & R & R & R \\
F & C & C & F & F & R & R\end{array}\right.$} & $\begin{array}{lllllll}R & R & R & R & R & R & R \\
C & C & F & F & C & C & C\end{array}$ & $\begin{array}{lllll}R & R & R \\
F & C & C & C & C\end{array}$ & $F F F F C C$ & $\begin{array}{l}R \times \\
F F F F F\end{array}$ & 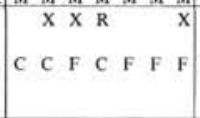 & 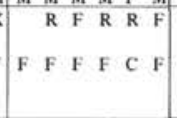 & $\begin{array}{lllllll}R & R & F & R & F & R & R \\
C & C & C & C & C & C & C\end{array}$ & $\begin{array}{llll}R X X & X \\
C & C F F & F F F\end{array}$ & 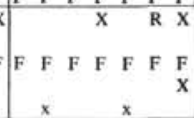 & $\begin{array}{llllll}R & R & X & X \\
C & F & F & F & C & C \\
X & & & & X\end{array}$ \\
\hline 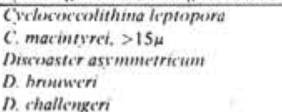 & $\begin{array}{lllllll}C & C & 1 & C & C & C & 1 \\
1 & 1 & R & 1 & 1 & 1 & F \\
R & R & & & & R\end{array}$ & $\mid \begin{array}{lllllll}C & C & C & C & C & C & C \\
F & C & F & F & C & C & C \\
R & R & R & R & R \\
R & R & R & R & R & F\end{array}$ & 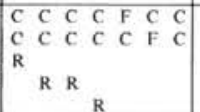 & $\begin{array}{lllllll}F & F & F & F & F & F & F \\
F & F & C & F & F & F & C\end{array}$ & $\begin{array}{llllll}F & F & F & C & C & C \\
F & F & F & F & R & R \\
& & & R\end{array}$ & $\mid \begin{array}{lllllll}C & C & C & C & C & C & C \\
C & F & C & F & F & F & F \\
R & & & & & R\end{array}$ & \begin{tabular}{lllllll|} 
& $F$ & $R$ & $F$ & $F$ & $F$ & $F$ \\
$R$ & $R$ & $R$ & $R$ & $F$ & $R$ \\
$R$ & & & & \\
$R$
\end{tabular} & $\begin{array}{lllllll}C & F & C & F & F & F & C \\
F & F & F & R & F & F & C \\
X & & & & & \\
X\end{array}$ & 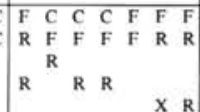 & 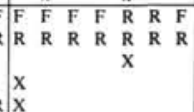 & $\begin{array}{llllllll}\text { F } & F & C & F & C & C & C \\
R & F & R & R & R & R & R \\
& & & & & & & \\
& & & & \end{array}$ \\
\hline $\begin{array}{l}\text { D. pentaradiatus } \\
\text { D. surculus } \\
\text { D. tamalis } \\
\text { D. variabilix } \\
\text { Discooster } \text { p. }\end{array}$ & 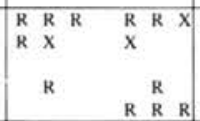 & $\mid \begin{array}{lllllll}R & F & F & R & R & R & F \\
& R & R & R & & & X \\
& & & & & \\
R & F & F & R & R & R & F\end{array}$ & \begin{tabular}{lllllll|} 
& $R$ & $R$ & $F$ & $R$ & & $R$ \\
& & & $R$ & $R$ & $R$ & \\
& & & & & & \\
$R$ & $R$ & $R$ & $R$ & & & $R$ \\
$R$ & $R$ & $F$ & $F$ & $R$ & $R$ & $F$
\end{tabular} & \begin{tabular}{|lllllll}
$R$ & $R$ & $X$ & & $R$ & $X$ \\
& & & & $R$ & $R$ \\
& & & & & $R$ \\
$R$ & & $R$ & $R$ & $F$ & $F$ & $R$
\end{tabular} & $\begin{array}{lllllll} & & & & & & \\
& & X & & & \\
& R & R & R & R\end{array}$ & 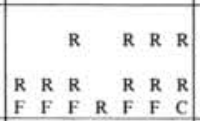 & 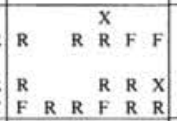 & 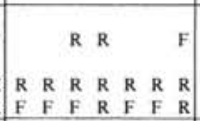 & $\begin{array}{lllllll}R & & & R & X & \\
R & R & R & F & R & R & F \\
R & R & R & R & R & R\end{array}$ & \begin{tabular}{|lllllll}
$R$ & & & & $X$ & \\
& & & & \\
$R$ & $R$ & $R$ & $R$ & $R$ & $R$ & $R$ \\
$R$ & $R$ & $F$ & $F$ & $F$ & $R$ & $R$ \\
\end{tabular} & 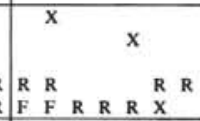 \\
\hline 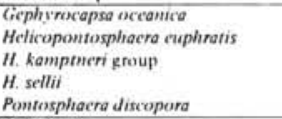 & F F F $F R F R$ & $=\begin{array}{ccc}R & F \\
R & F\end{array}$ & $\begin{array}{llllllll} & F & F & R & R & & & \\
& & F & F & F & F & F \\
& & & & & R & R\end{array}$ & $=\begin{array}{llllllll}R & R & & X & X \\
F & F & F & F & C & F & F \\
& & & & & & & \\
\end{array}$ & $\begin{array}{llllll}R & R & & X \\
F & F & F & R & R & R\end{array}$ & $\begin{array}{lllllll}F & F & R & & R & \\
F & F & F & F & F & F & F\end{array}$ & $\begin{array}{llllll} & & R & & R \\
R & R & R & F & F & F\end{array}$ & $\left|\begin{array}{lllllll}R & R & R & F & R & R \\
R & F & F & F & F & F & F\end{array}\right|$ & $\mathrm{FF}$ & $R$ R & $\begin{array}{r}\text { R R R R R R R } \\
x\end{array}$ \\
\hline 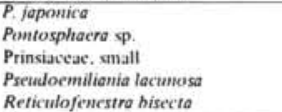 & $\begin{array}{lllllll}F & F & A & F & F & F & B \\
A & A & A & A & A & A & A\end{array} \mid$ & $\left|\begin{array}{ccccccc}F & F & F & F & F & F & F \\
A & A & A & A & A & A & A\end{array}\right|$ & $\left|\begin{array}{lllllll}F & F & F & F & R & F & R \\
A & A & A & A & A & C & A\end{array}\right|$ & $\begin{array}{lllllll}F & F & F & R & R & R & F \\
A & A & A & A & A & A & A\end{array}$ & $\begin{array}{llllll}R & F & R & R & R & R \\
C & A & A & A & A & A\end{array} \mid$ & $\begin{array}{lllllll}F & R & F & R & R & & \\
A & A & A & A & A & A & A\end{array}$ & $A \begin{array}{llllll}R & R & & \\
A & A & A & A\end{array}$ & 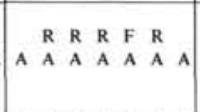 & $\begin{array}{llllll}R & R & & X \\
A & A & A & A & A & A\end{array}$ & $\begin{array}{lllllll}R & R & R & R & R & R & R \\
A & A & A & A & A & A & A\end{array}$ & $\begin{array}{lllllll}R & R & & R & R & R \\
A & A & A & A & A & A & A\end{array}$ \\
\hline 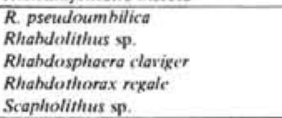 & $\begin{array}{lllllll}C & A & C & C & C & C & C \\
F & R & R & & \\
F & F & F & R & F & F \\
R & R & & R & R & R \\
R & & & R & R\end{array}$ & $\begin{array}{lllllll}C & F & F & F & F & R & F \\
& R & R & & & X \\
F & R & F & R & F & F & F\end{array}$ & $\mid$\begin{tabular}{ccccccc|} 
F & $F$ & $F$ & $C$ & $C$ & $C$ & $C$ \\
$R$ & $R$ & $R$ & $R$ & $R$ & $R$ & $F$ \\
$R$ & & $R$ & & \\
$R$ & & $R$ &
\end{tabular} & $\begin{array}{l}A A A A A A C \\
F R A R A R\end{array}$ & $\left|\begin{array}{llllll}A & C & C & C & A & A \\
R & R & R & R & R & R\end{array}\right|$ & $\left|\begin{array}{lllllll}A & C & A & A & A & A & A \\
R & R & R & R & R & X\end{array}\right|$ & ${ }_{R}^{A A A A A C}$ & $\begin{array}{lllllll}A & A & A & A & A & A & A \\
R & R & R & R & F & R & F\end{array}$ & $\begin{array}{r}C A A A A A A \\
\\
\\
x\end{array}$ & $A A A A C A A$ & $\begin{array}{l}A \text { A A C C C A } \\
X_{R} X\end{array}$ \\
\hline 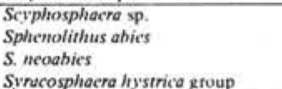 & $\begin{array}{|lllllll|}F & R & F & R & R & F & R \\
& & R & & R & R \\
F & R & R & F & R & R & R \\
F & R & F & F & F & F & F\end{array}$ & $\begin{array}{lllllll}F & F & F & F & F & F & F \\
R & R & R & R & R & F & R \\
F & F & R & F & F & F & F \\
F & R & F & F & F & \end{array}$ & \begin{tabular}{lllllll|}
$F$ & $F$ & $F$ & $R$ & $R$ & $F$ & $F$ \\
$R$ & $R$ & $R$ & $F$ & $R$ & $F$ & $F$ \\
$F$ & $F$ & $C$ & $C$ & $F$ & $F$ & $F$ \\
$R$ & & & & $F$ & \\
\end{tabular} & 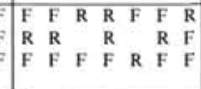 & $\begin{array}{lllllll}R & R & R & R & F & R \\
R & R & R & R & R & R \\
R & R & R & F & F & R \\
& & & & & \end{array}$ & $\begin{array}{lllllll}F & R & F & R & R & F & R \\
R & R & R & R & F & R & F \\
R & F & F & C & F & F & F\end{array}$ & 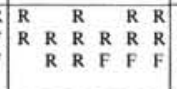 & $\mid \begin{array}{lllllll}R & R & R & R & F & R & R \\
R & R & R & R & R & F & F \\
F & C & F & F & C & F & F\end{array}$ & $\begin{array}{lllll}R & R & R & R & R \\
X & X & & R \\
R & X & & & R \\
R\end{array}$ & $\begin{array}{lllllll}X & & X & R & R & R & R \\
R & R & R & & R & R & R \\
F & F & F & R & R & R & F\end{array}$ & $\begin{array}{lllllll}R & F & R & R & R & R & R \\
F & R & F & R & F & F & F \\
C & C & F & F & F & F & F\end{array}$ \\
\hline $\begin{array}{l}\text { Thorcosphheera sp. } \\
\text { Trizuerporhahdulus nuposus } \\
\text { Trochoaster } \$ \text {. }\end{array}$ & $\begin{array}{lll}\mathrm{R} & \mathrm{R} & \mathrm{R}\end{array}$ & $\bar{R}$ & $\begin{array}{ll}\mathrm{R} & \mathrm{R} R \\
\mathrm{R}\end{array}$ & $x R$ & $\mathbf{R}$ & RRR & RRARRF & $R F R R R R R$ & $R R R R$ & $R R R R$ & $\begin{array}{lllllll} & & & X & \\
& & & \\
R & R & R & R & R & R & R\end{array}$ \\
\hline
\end{tabular}


TABLE 12

Additional Species Observed but not Listed in Tables 4-11

\section{Site 277 (see Table 4)}

Braarudorphaera bigelowi- $\mathrm{R}$ in Samples 40, CC; 41-2, $111 \mathrm{~cm}$; 43, CC.

Camphylosphaera dala- $\mathrm{R}$ in Sample 43-3, $121 \mathrm{~cm}$.

Cruciplacolithus mustahus-R in Sample 36-2, $108 \mathrm{~cm}$.

Discoaster mecliosus-R in Samples 44-1, $101 \mathrm{~cm} ; 44-2,130 \mathrm{~cm}$; $44-3,127 \mathrm{~cm}$.

D. taris-R in Samples 34-2, $110 \mathrm{~cm} ; 34$, CC.

Helicopontosphaera salebrosa- $\mathrm{R}$ in Sample $33-1,120 \mathrm{~cm}$.

H. seimnulum-R in Samples 38-2, $110 \mathrm{~cm} ; 39, \mathrm{CC} ; 40-2,110 \mathrm{~cm}$; $40-3,117 \mathrm{~cm}$.

Lophodolithus mochloporus-R in Samples 40-3, $117 \mathrm{~cm}$; 40, CC; $41-1,113 \mathrm{~cm}$.

L. nascens- $\mathrm{R}$ in Samples 42-3, $114 \mathrm{~cm} ; 42, \mathrm{CC}$.

Markalius reinhardtii- $\mathrm{R}$ in Samples $44-2,20 \mathrm{~cm} ; 45-5,111 \mathrm{~cm}$.

Micrantholithus sp.-R in Sample 40-3,117 cm.

Nannotetrina cristata- $\mathrm{R}$ in Samples 35-1, $105 \mathrm{~cm} ; 35-2,104 \mathrm{~cm}$; $36, \mathrm{CC}$.

Neochiastogugus junctus $-\mathrm{R}$ in Samples $44-2,20 \mathrm{~cm} ; 44-2,90 \mathrm{~cm}$. N. perfectus $-\mathrm{R}$ in Sample $46-2,118 \mathrm{~cm}$.

Neococcolithes minubus-R in Samples 44, CC; 43-1, $117 \mathrm{~cm}$.

$N$. protenus-R in Samples 45-3, $127 \mathrm{~cm} ; 46-2,118 \mathrm{~cm}$.

Rhabdolithus tenuis?-R in Samples 38-3, $122 \mathrm{~cm} ; 39-2,110 \mathrm{~cm}$; $39-3,120 \mathrm{~cm}$.

Transvesophonhis puleheroides- $\mathrm{R}$ in Sample 40-3, $177 \mathrm{~cm}$.

Zygodiscus plectopons- $\mathrm{R}$ in Sample 41-2, $111 \mathrm{~cm}$.

Z. sigmoides $-\mathrm{R}$ in Sample 45-3,127 cm.

\section{Site 278 (see Table 5)}

Discoaster brouweri-1 in Sample 18-2, $110 \mathrm{~cm}$; R in Sample 18-1, $110 \mathrm{~cm}$.

D. cf. D. calcaris-1 in Sample 18-2, $110 \mathrm{~cm}$; R in Sample 17, CC.

D. druggi-kugleri group-1 in Samples 26, CC; 23, CC;23-5; $110 \mathrm{~cm}$. $23-1,110 \mathrm{~cm}$.

D. lodoensis-1 in Sample 17, CC

Ericsonia tenestrata s.l.-1 in Sample 32-3, $110 \mathrm{~cm}$.

Helicopontosphaera kamptneri-1 in Samples 20, CC; 16-6, $110 \mathrm{~cm}$.

\section{Site 279 (see Table 6)}

Chiasmolithus alhus-1 in Samples 279A-6-4, 56 cm; 279A-3-6, 125 $\mathrm{cm} ; 2$ 279A-9, CC.

Helicopontosphaera ampliaperta- $\mathrm{R}$ in Sample 279A-5, CC.

Hornibrookina australis-1 in Sample 279A-8-1, $114 \mathrm{~cm}$.

Micrantholithus sp.-1 in Sample 279A-6-4, $56 \mathrm{~cm}$.

Rhabdosphaera skylifer-1 in Sample 279-1-1, $80 \mathrm{~cm}$.

Rhabdothorax regale-1 in Sample 279-1-1, $80 \mathrm{~cm}$.

Sphenolibluis cf. S. capricornutus 279A-6-4, $56 \mathrm{~cm}$.

Triquetrorhabdulus milowii-1 in Sample 279A-3-1, $140 \mathrm{~cm}$.

Zygrhablithus bijugatus-1 in Sample 279A-3-4, $110 \mathrm{~cm}$.

\section{Site 282/I (see Table 9)}

Blackites rectus?-1 in Sample 11-1, $136 \mathrm{~cm} ; 11-3,110 \mathrm{~cm}$; F in Sample 11, CC.

D. divaricatus-F in Sample 2, CC; 3, CC; 4, CC.

Helicopontosphaera compacta-1 in Sample 12-2, $115 \mathrm{~cm}$.

H. obliqua-F in Sample 5, CC.

Lanternithus minutus-R in Samples $11-1,130 \mathrm{~cm} ; 11-2,110 \mathrm{~cm}$. Reticulofenestra abisecta-C in Sample 5, CC.

$R$. oamaruensis?-1 in Sample 11-2, $110 \mathrm{~cm}$.

Rhabdosphaera skylifer $-\mathrm{F}$ in Sample 1-1, $75 \mathrm{~cm}$; R in Sample 1-1, $101 \mathrm{~cm}$.

Scapholithus sp.-R in Sample 1-1, $75 \mathrm{~cm}$.

Sphenolithus abies-F in Samples 2, CC; 5-1, $127 \mathrm{~cm} ; 5-2,40 \mathrm{~cm}$. $S$. heteromorphus -1 in Sample $1-4,130 \mathrm{~cm}$.

Transversopontis sp.- $\mathrm{R}$ in Samples 11-1, $136 \mathrm{~cm} ; 11-2,110 \mathrm{~cm}$. Trachoaster sp.-1 in Sample 11, CC.

Umbilicosphaera mirabilis $-\mathrm{R}$ in Sample 1-1, $75 \mathrm{~cm}$.

\section{Site 282/II (see Table 9)}

Chiasmolithus solitus-F in Sample 17, CC; R? in Core 18 (top). Coramulus germaincus?-Sample 16, CC.

Coronocyclus uifescens- $\mathrm{R}$ in Samples 13-5, $110 \mathrm{~cm} ; 14-3,107 \mathrm{~cm}$. Cruciplacolithus sp.-1 in Samples 15-2, $66 \mathrm{~cm} ; 15-3,30 \mathrm{~cm} ; 15$, CC. Discoaster binodosus binodosus-R in Core 18 (top).

Helicopontosphaera dinesenii-1 in Samples 17-3, $110 \mathrm{~cm} ; 17-4$, $110 \mathrm{~cm}$.

H. lophota-1 in Samples 17-3, $110 \mathrm{~cm} ; 15-2,63 \mathrm{~cm}$.

H. cf. $H$. salebrosa-1 in Sample 17-4, $110 \mathrm{~cm}$; R in Sample 17, CC. Helicopontosphaera sp.-F in Sample 13-4, 23; 1 in Sample 14-2, $110 \mathrm{~cm}$.

Neococcolithites dubius $-\mathrm{R}$ in Samples 17-3, $110 \mathrm{~cm} ; 17-4,110 \mathrm{~cm}$.

N. minutus -1 in Samples 17-3, $110 \mathrm{~cm} ; 17-4,110 \mathrm{~cm}$; R in Sample $17, \mathrm{CC}$.

Orthozygus aurcus-R? in Sample 13-1, $130 \mathrm{~cm}$; 1 in Sample 16-1, $110 \mathrm{~cm}$.

Reticulofenestra oamaruensis-F? in Sample 15-2, $66 \mathrm{~cm}$.

Rhabdolitus vitrea $\mathrm{R}$ in Sample 13-4, $23 \mathrm{~cm}$.

Sphenolithus sp.-R in Samples 15, CC; 17-3, $110 \mathrm{~cm}$.

Trausversopontis sp.-1 in Samples 16-1, $110 \mathrm{~cm} ; 17-3,110 \mathrm{~cm}$; $17, \mathrm{CC}$.

Holococcolith-1 in Sample 17-3, $110 \mathrm{~cm}$.

\section{Site 283 (see Table 10)}

Table 10 includes all coccoliths and nannoliths observed down to Sample 9, CC. At least one sample per section was searched for calcareous nannofossils down to Sample 17, CC. While most samples proved to be barren, the following included very rare and poorly preserved small Reticulofenestra, and occasionally Ericsonia ovalis: Samples 10, CC; 11-2, $117 \mathrm{~cm} ; 13-2,111 \mathrm{~cm} ; 13-5,104 \mathrm{~cm} ; 14-2$ $114 \mathrm{~cm} ; 14, \mathrm{CC} ; 15-31,114 \mathrm{~cm}$; and $17-5,35 \mathrm{~cm}$.

Note: See Table 4A for explanation of symbols. 



\section{PLATE 1}

Calcareous nannofossils from Sample 277-46-2, $118 \mathrm{~cm}$; Paleocene.

(Figures 1-9, $11 \times 5700$; Figures $10,12-15, \times 11,500$ )

Figure $1 \quad$ Sphenolithus sp. Side view of specimen reminiscent of $S$. primus Perch-Nielsen; heavy overgrowth.

Figures 2-8 Fasciculithus tympaniformis Hay and Mohler. Varying degrees of solution and overgrowth. 2, 3. Distal views.

$4,5,7,8$. Side views.

6. Proximal view.

Figure 9 Neochiastozygus junctus (Bramlette and Sullivan). Proximal view; damaged specimen.

Figure $10 \quad$ Neochiastozygus sp. 1. Distal view; some selective overgrowth.

Figure $11 \quad$ Neococcolithes protenus (Bramlette and Sullivan). Distal view; heavy overgrowth in center.

Figure 12 Neochiastozygus sp. 2. Distal view; overgrowth in center.

Figures 13-15 Neochiastozygus of. N. modestus Perch-Nielsen.

13, 14. Distal views; some overgrowth in center.

15. Proximal view; some overgrowth in center. 
PLATE 1
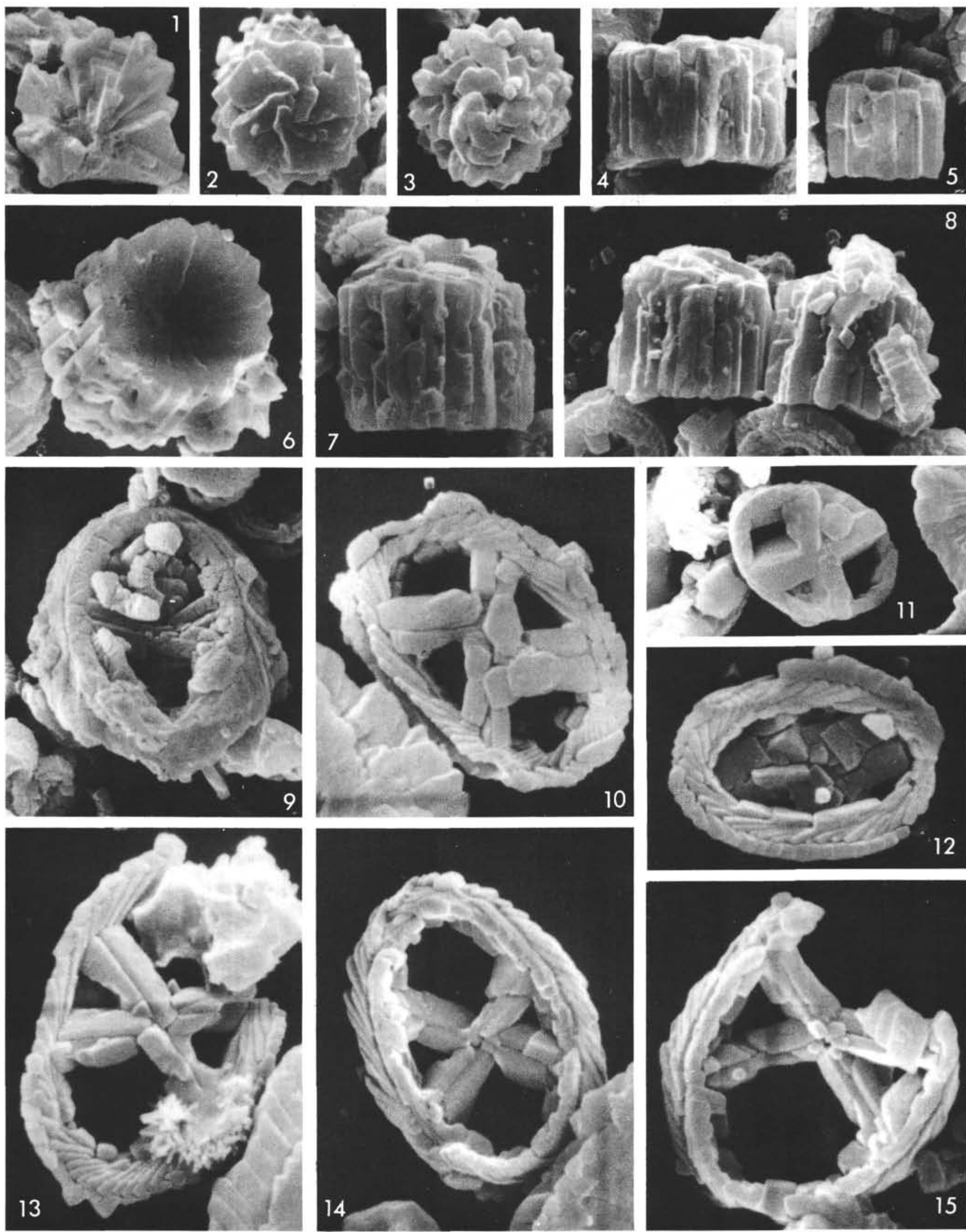


\section{PLATE 2}

Calcareous nannofossils from Sample 277-45-2, $118 \mathrm{~cm}$; Paleocene.

Figures 1-3, 6, Hornibrookina australis n. sp. $\times 11,200$.

9,12 1-3, 12. Distal views.

6. Paratype; proximal view.

9. Holotype; distal view.

Figures 4, 7, Chiasmolithus danicus (Brotzen). $\times 11,500$.

114,11 . Distal views; little overgrowth

7. Heavy selective overgrowth.

Figure 5 Ericsonia? sp. Distal view; $\times 11,500$.

Figure 8 Chiasmolithus bidens (Bramlette and Sullivan). Distal view; diffuse overgrowth; $\times 5700$.

Figure 10 Chiasmolithus cf. C. eograndis Perch-Nielsen. Distal view, some overgrowth; $\times 5700$. 
PLATE 2
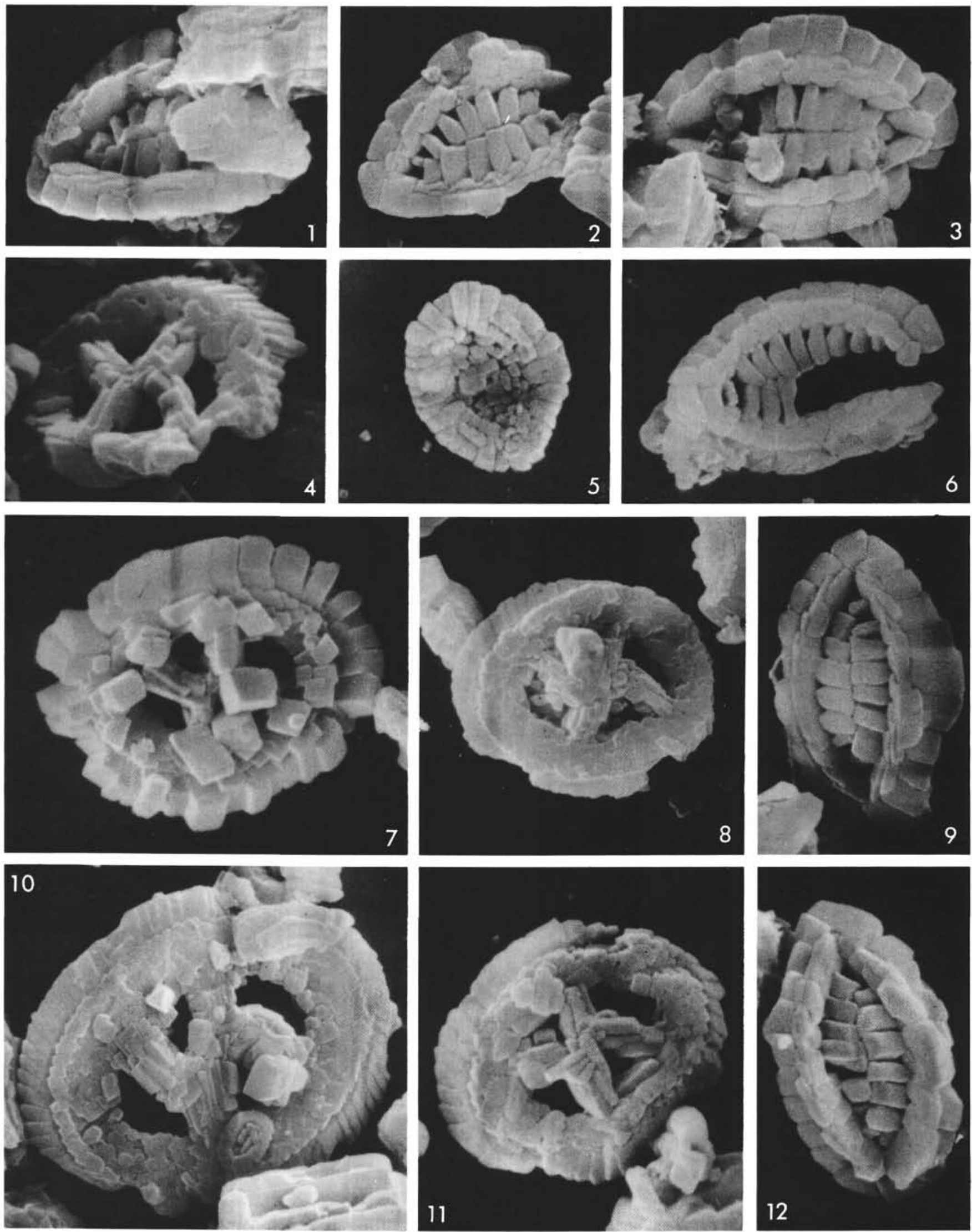


\section{PLATE 3}

Calcareous nannofossils from Sample 277-45-3, $127 \mathrm{~cm}$; Paleocene.

(Figures 1-11, $\times 11,400$; Figures 12, 13, ×5700)

Figures 1, 2, 4, Neochiastozygus distentus (Bramlette and $5,7,10 \quad$ Sullivan).

1. Proximal view.

2, 4, 5, 7. Distal views; overgrowth.

10. Distal view; first wall visible.

Figures 3, 6, Toweius craticulus Hay and Mohler.

$8,93,6$. Proximal views; etching and overgrowth.

8, 9. Distal views.

Figure $11 \quad$ Neococcolithes protenus (Bramlette and Sullivan). Distal view; center heavily overgrown.

Figure 12 Toweius callosus Perch-Nielsen. Distal view; some overgrowth.

Figure 13 Toweius cf. T. occultatus (Locker). Distal view of specimen which could be either $T$. occultatus with an additional central net, or $T$. craticulus with an additional set of radial elements (due to overgrowth only?). 
PLATE 3
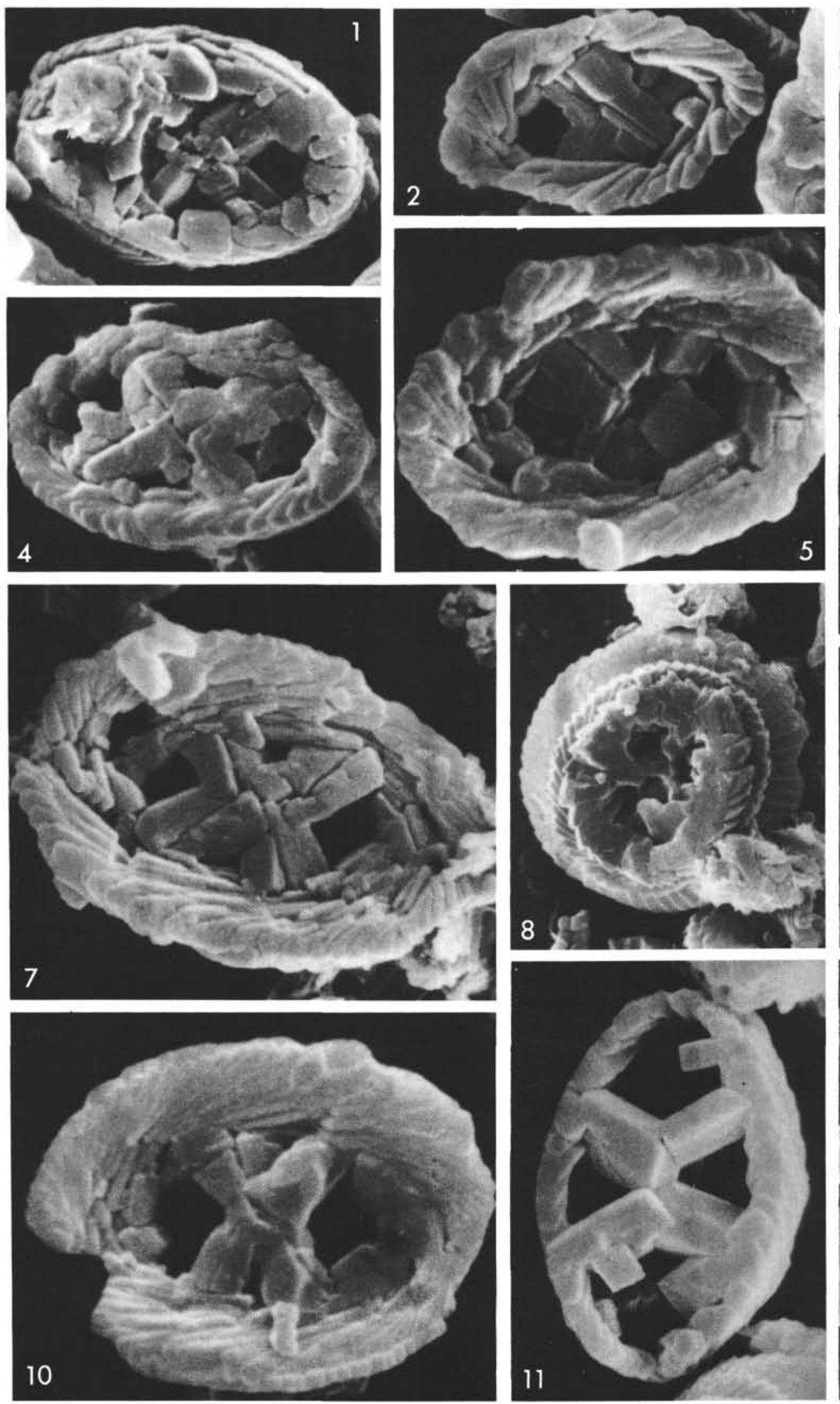
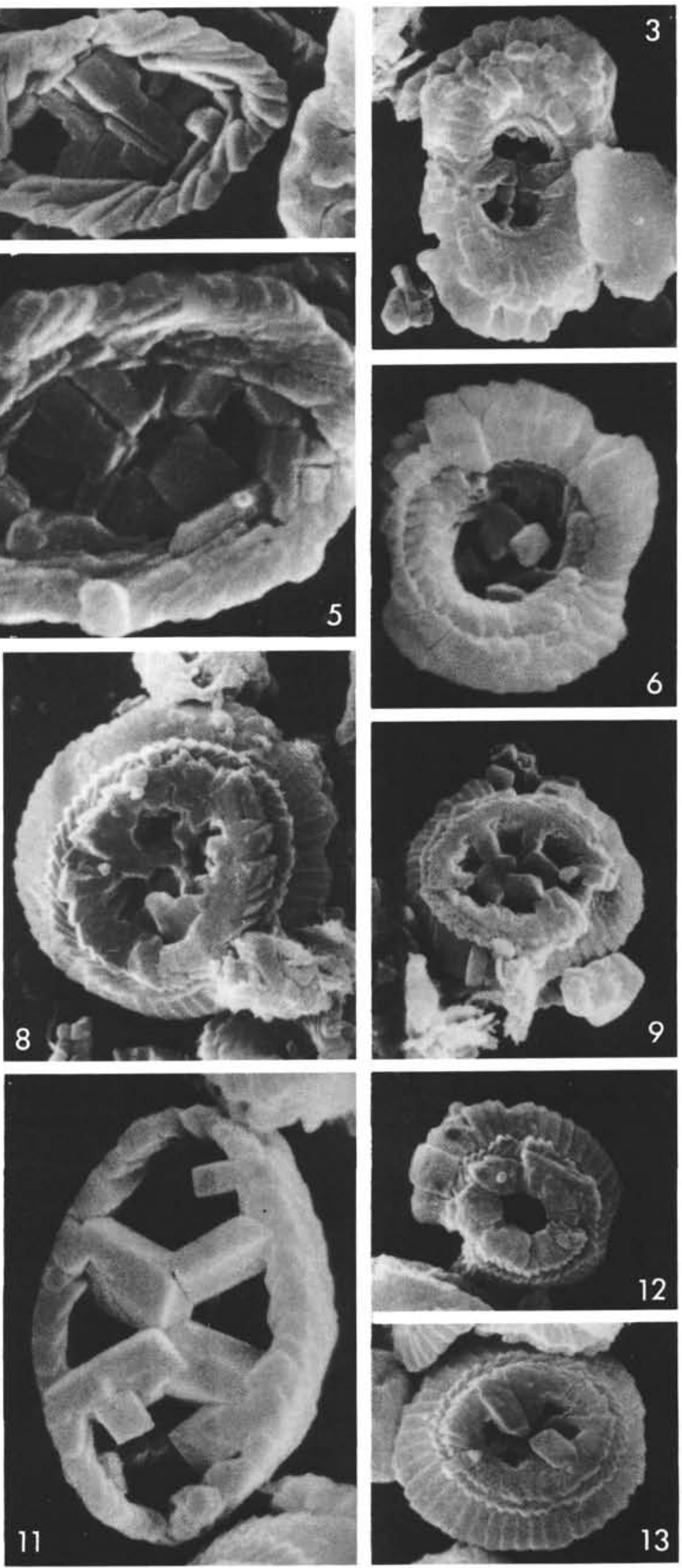
PLATE 4

Calcareous nannofossils from Sample 277-45-3, $127 \mathrm{~cm}$; Paleocene (All figures $\times 12,000)$

Figures 1, 2 Neochiastozygus distentus (Bramlette and Sullivan). Distal views; some overgrowth.

Figure 3 Discoaster? sp. 1.

Figure 4 Toweius eminens (Bramlette and Sullivan). Distal view; specimen badly damaged.

Figure 5 Discoaster multiradiatus Bramlette and Riedel. Distal view; selective overgrowth.

Figure 6 Toweius craticulus Hay and Mohler. Distal view; some overgrowth in center.

Figure 7 Zygodiscus sigmoides Bramlette and Sullivan. Proximal view. 
PLATE 4
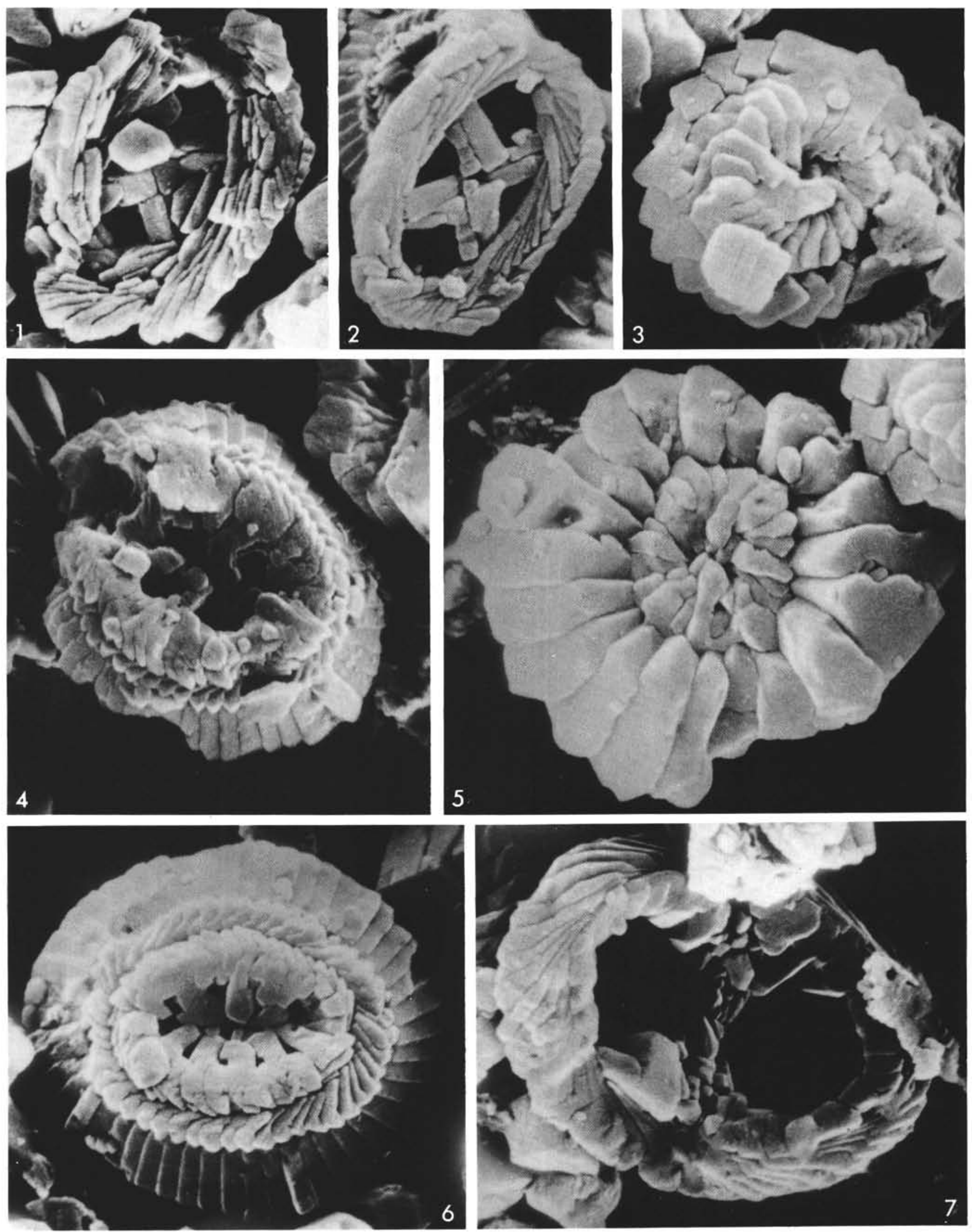
A. R. EDWARDS, K. PERCH-NIELSEN

\section{PLATE 5}

Paleocene calcareous nannofossils.

(Figures 1-8, 10-12, Sample 277-45-3, $127 \mathrm{~cm}$;

Figure 9, Sample 277-45-2, $118 \mathrm{~cm}$ )

Figures 1-3 Fasciculithus tympaniformis Hay and Mohler. $\times 5700$. Some overgrowth.

Figures 4, 7, Discoaster multiradiatus Bramlette and Riedel. 10 $\times 5700$.

4. Distal view; heavily overgrown.

7, 10. Proximal views.

Figure $5 \quad$ Chiasmolithus danicus $($ Brotzen). $\times 5700$. Distal view; overgrowth in center.

Figures 6, 9, Hornibrookina australis n. sp. $\times 11,400$.
6. Proximal view.

9, 12. Distal views.

Figures 8, 11 Chiasmolithus eograndis Perch-Nielsen. $\times 5700$. Distal and proximal views; diffuse overgrowth. 
PLATE 5
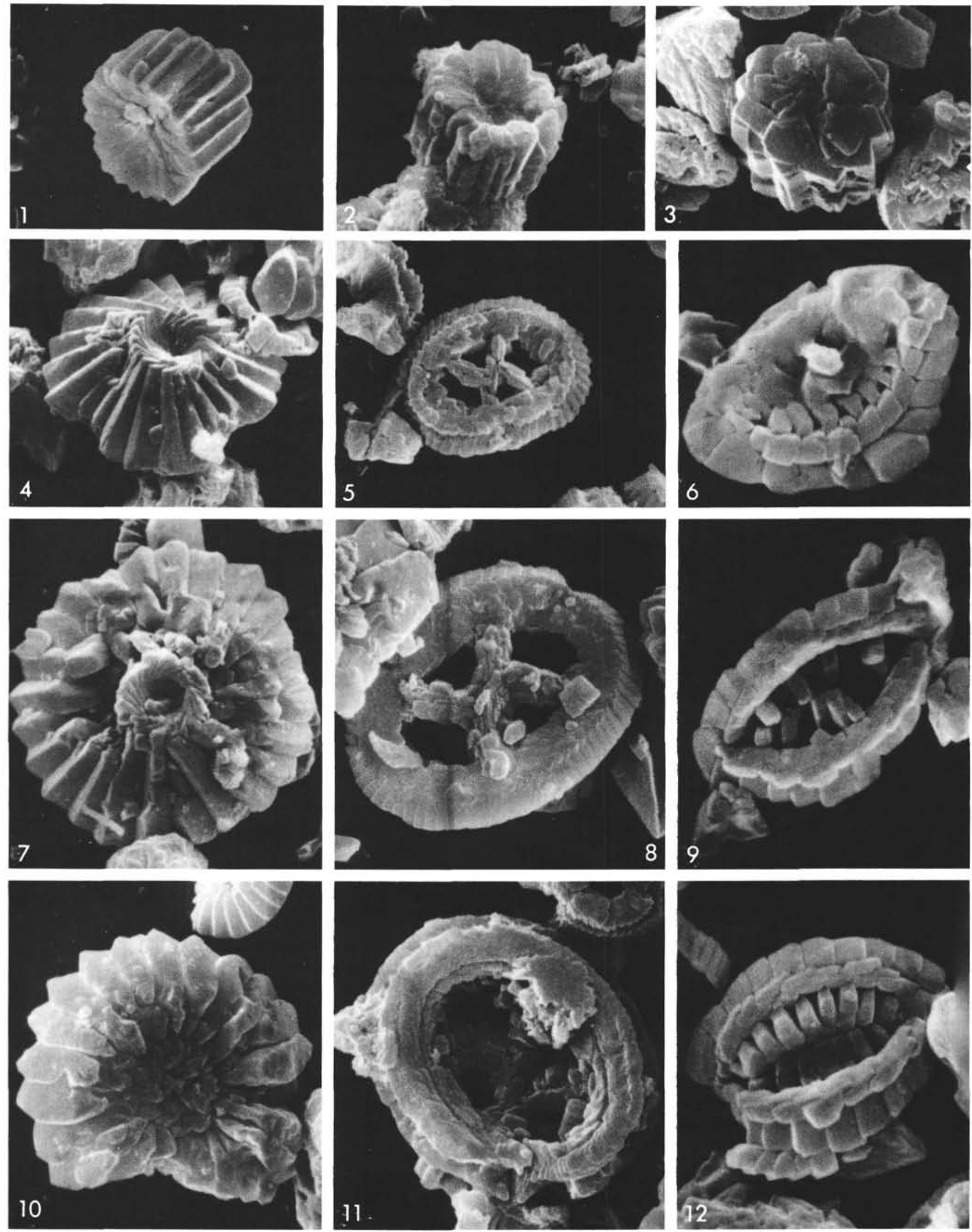
A. R. EDWARDS, K. PERCH-NIELSEN

\section{PLATE 6}

Calcareous nannofossils from Sample 277-44-2, $20 \mathrm{~cm}$; early Eocene.

Figures $1,4 \quad$ Neochiastozygus sp. 3. $\times 5200$. Distal and proximal views; overgrowth.

Figure 2 Sphenolithus sp. 2. $\times 5200$. Distal view; overgrowth.

Figure 3 Chiasmolithus cf. C. danicus (Brotzen). $\times 5500$. Distal view; diffuse overgrowth in center.

Figure $5 \quad$ Ericsonia robusta $($ Bramlette and Sullivan). $\times 5200$. Proximal view; diffuse overgrowth.

Figures 6, 10, Chiasmolithus eograndis Perch-Nielsen. $\times 5200$. $14,156,10,15$. Distal views; varying overgrowth. 14. Proximal view.

Figures 7, 8 Neococcolithes protenus (Bramlette and Sullivan). $\times 5500$. Distal views; center heavily overgrown.

Figure 9 Toweius callosus Perch-Nielsen. $\times 5200$. Distal view; some overgrowth on second wall.

Figures 11,13 Discoaster robustus Haq. $\times 5200$. Proximal views.

Figure 12 "Chiasmolithus" consuetus (Bramlette and Sullivan). $\times 5200$. Distal view; selective overgrowth. 
PLATE 6
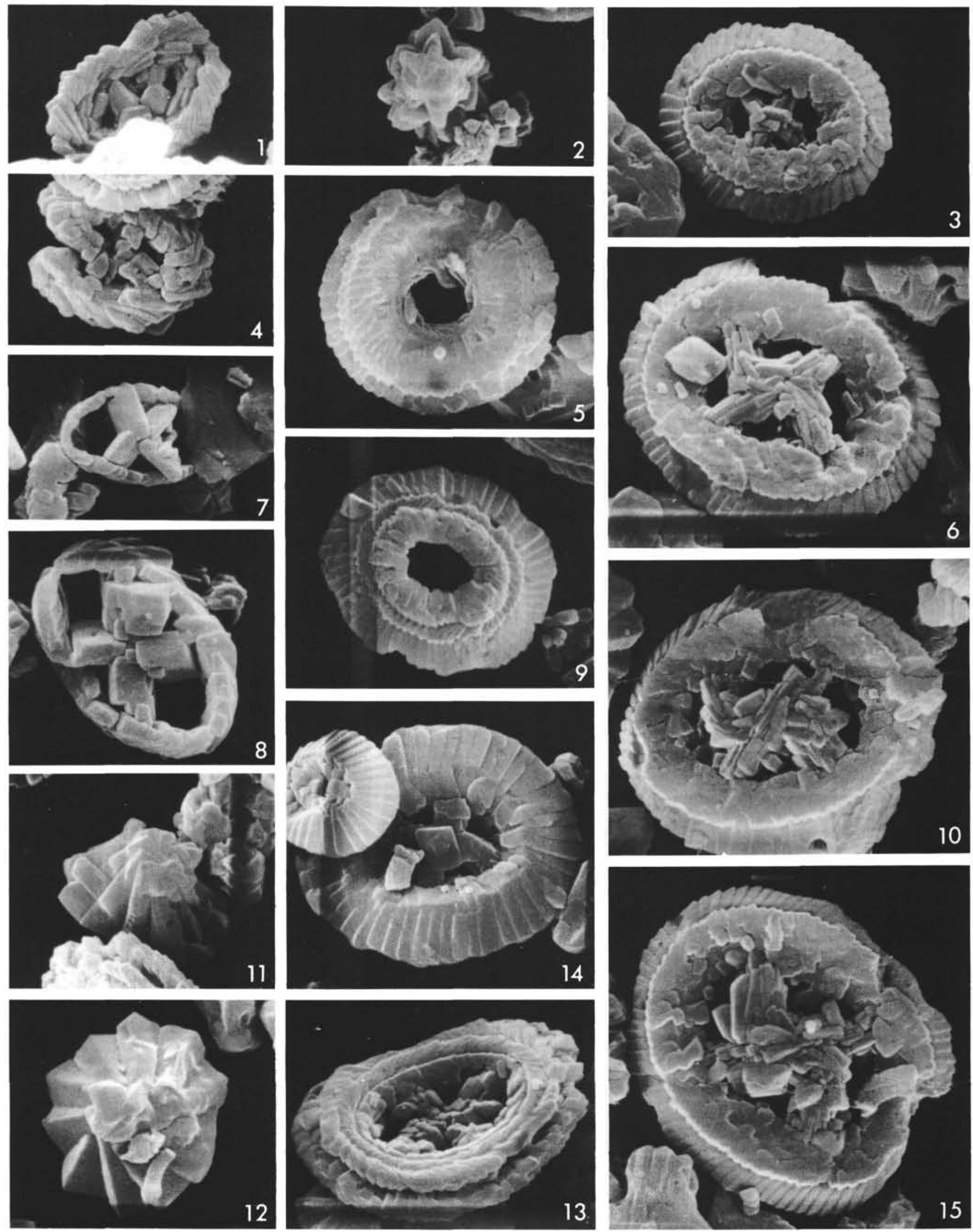
PLATE 7

Calcareous nannofossils.

(Figure 1, Sample 277-45-3, $127 \mathrm{~cm}$; Paleocene.

Figures 2-9, Sample 277-43-3, $121 \mathrm{~cm}$; early Eocene)

Figure 1 Chiasmolithus sp. $\times 12,000$. Distal view; dissolution.

Figure 2 Discolithina sp. 1. $\times 6000$. Distal view.

Figure 3 Sphenolithus radians Deflandre. $\times 12,000$. Side view; overgrowth.

Figures 4, 7 Chiasmolithus eograndis Perch-Nielsen. $\times 6000$. Proximal and distal views; specimens damaged.

Figure $5 \quad$ Markalius astroporus $($ Stradner). $\times 12,000$. Proximal view; overgrowth in center.

Figure $6 \quad$ Sphenolithus sp. 3 (moriformis group). $\times 12,000$. Side view, overgrowth.

Figure $8 \quad$ Toweius callosus Perch-Nielsen. $\times 12,000$. Distal view; damaged specimen.

Figure $9 \quad$ Zygrhablithus bijugatus Deflandre. $\times 6000$. Heavily overgrown. 
PLATE 7
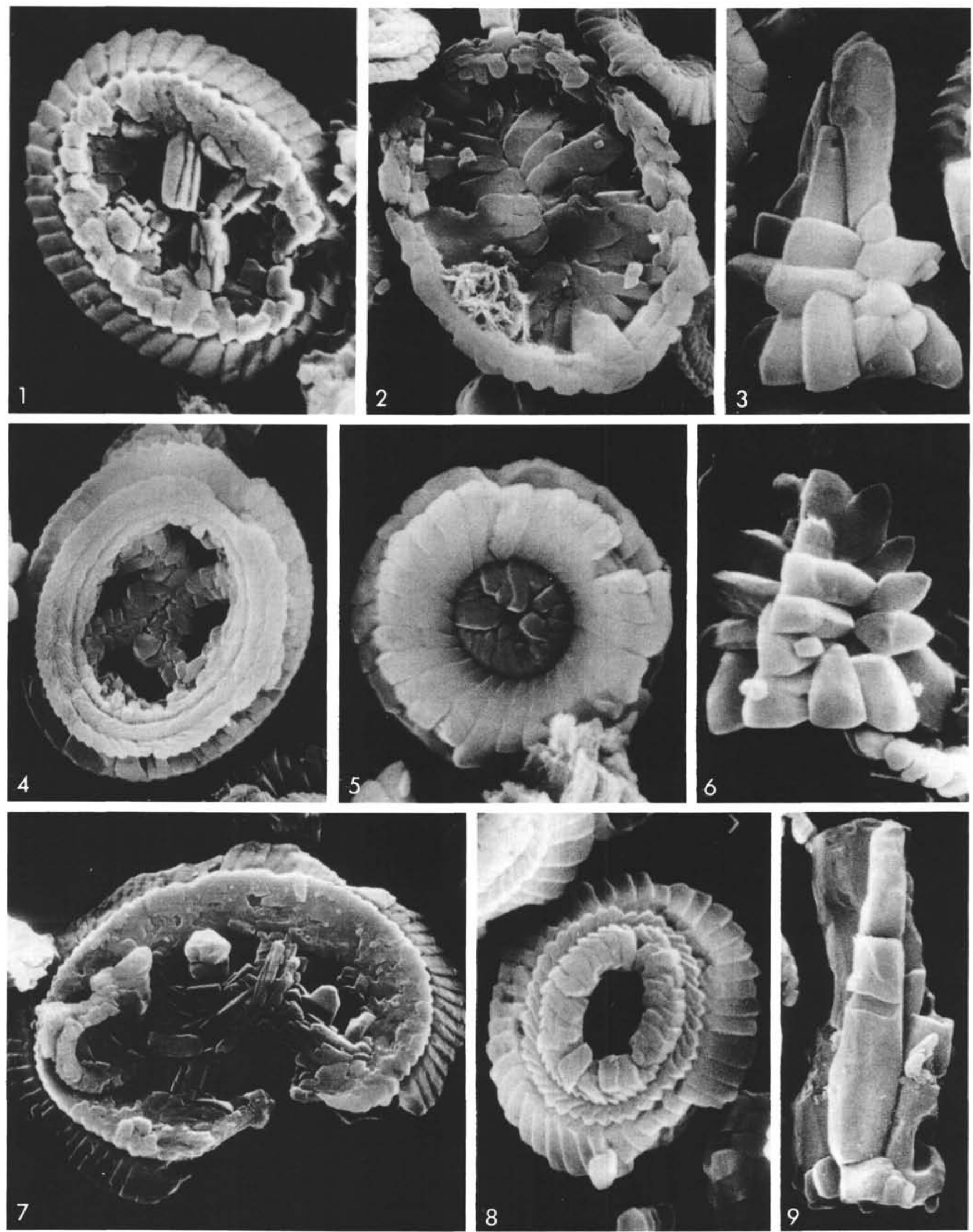


\section{PLATE 8}

Calcareous nannofossils.

(Figures 1, 3, 4, 6-9, 11, Sample 277-45-2, $118 \mathrm{~cm}$; Paleocene. Figures 2, 5, 10, Sample 277-40, CC; Eocene)

Figure 1 Ellipsolithus distichus (Bramlette and Sullivan). $\times 5700$. Distal view; damaged specimen.

Figure 2 Toweius craticulus Hay and Mohler. $\times 11,500$. Proximal view; damaged specimen.

Figure 3 Biscutum panis (Edwards) n. comb. (Basionym: Conococcolithus panis Edwards 1973, p. 73, fig. 221.) $\times 11,200$. Damaged specimen.

Figure 4 Discoaster multiradiatus Bram-lette and Riedel. $\times 5700$. Oblique distal view; damaged specimen.

Figures 5, 10, Zygrhablithus bijugatus Deflandre. $\times 5700$. Heavy 11 overgrowth.

Figure $6 \quad$ Neococcolithes protenus (Bramlette and Sullivan). $\times 11,200$. Distal view; selective overgrowth.

Figure $7 \quad$ Fasciculithus ? sp. 1. Note internal structure not previously observed in fasciculiths. $\times 11,500$.

Figure $8 \quad$ Markalius astroporus $($ Stradner). $\times 5700$. Distal view; minor overgrowth in center.

Figure 9 Nannolith. (Possibly stem of Discoaster multiradiatus?); $\times 5600$. 
PLATE 8
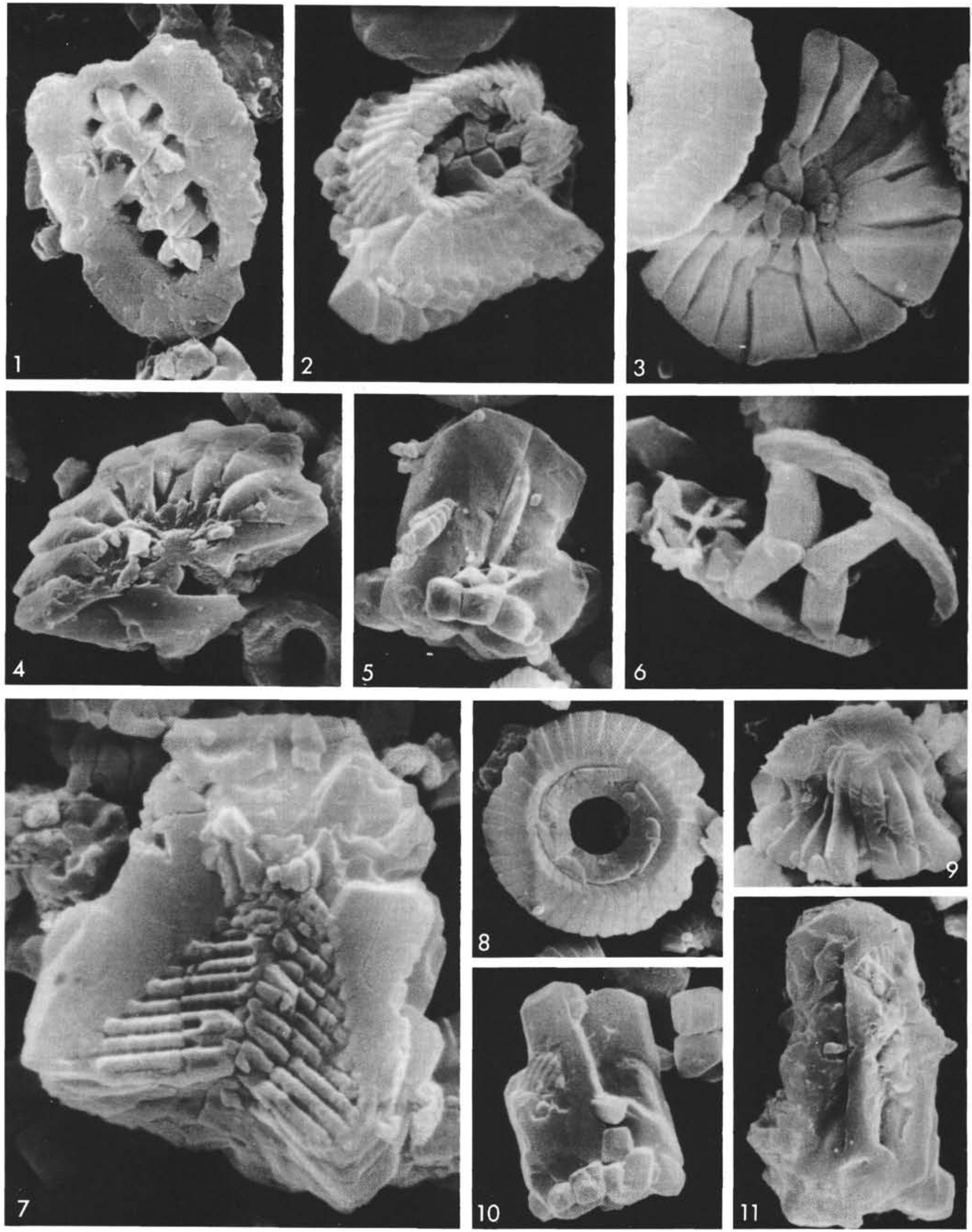


\section{PLATE 9}

Calcareous nannofossils; Sample 277-40, CC; Eocene.

(Figures 1-4, 7, 8, 13, ×5700; Figures 5, 6, 9-12, ×11,400)

Figures 1-3 Helicopontosphaera seminulum (Bramlette and Sullivan). Distal and proximal views.

Figure $4 \quad$ Neococcolithes protenus (Bramlette and Sullivan). Distal view; center heavily overgrown.

Figure $5 \quad$ Reticulofenestra dictyoda (Deflandre and Fert). Distal view; damaged specimen; selective overgrowth.

Figure 6 Toweius callosus ? Perch-Nielsen. Distal view; some overgrowth.

Figures 7, 8 Discoasteroides kuepperi (Stradner). Proximal and distal views; partly overgrown.

Figure $9 \quad$ Markalius astroporus (Stradner). Relatively wide central area has suffered more under recrystallization than the shield. Distal view.

Figure 10 Sphenolithus radians Deflandre. Heavy overgrowth.

Figure $11 \quad$ Markalius? sp. 1. Proximal view of distal shield?

Figure 12 Ring of elements of a broken coccolith or whole coccolith(?); $\times 11,400$.

Figure 13 Coronocyclus prionion (Deflandre and Fert). Distal view. 
PLATE 9
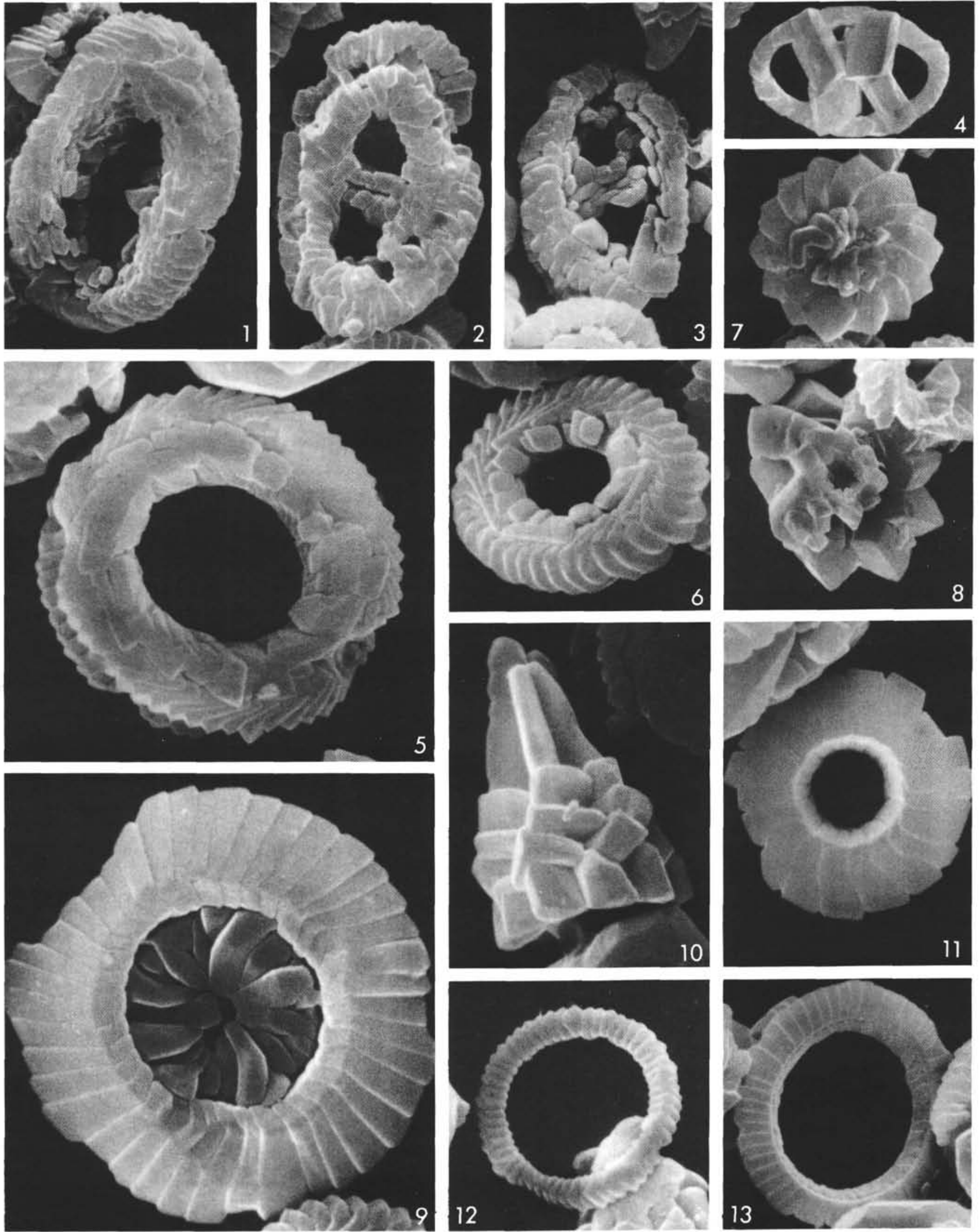
PLATE 10

Calcareous nannofossils; Sample 277-33-1, $120 \mathrm{~cm}$; Eocene.

Figures 1, 5, Chiasmolithus solitus (Bramlette and Sullivan). 11 $\times 6000$. Distal views.

Figures 2-4 Neococcolithes dubius (Deflandre). $\times 9000$. Distal views; heavy overgrowth in centers.

Figure 6 Sphenolithus radians s.l. Deflandre. $\times 12,000$. Side view; some overgrowth.

Figure 7 Helicopontosphaera sp. 1. $\times 6000$. Distal view; damaged specimen.

Figure $8 \quad$ Chiasmolithus expansus (Bramlette and Sullivan). $\times 6000$. Proximal view.

Figure 9 Sphenolithus moriformis s.l. (Brönnimann and Stradner). $\times 12,000$. Side view; heavy overgrowth.

Figures 10, 12 Helicopontosphaera salebrasa Perch-Nielsen. $\times 6000$. Distal and proximal views. 
PLATE 10



\section{PLATE 11}

Calcareous nannofossils; Sample 277-33-1, $120 \mathrm{~cm}$; Eocene.

Figure $1 \quad$ Rhabdolith. $\times 6100$. Broken stem.

Figure 2 Discoaster sp. $2 . \times 6000$. Heavy overgrowth.

Figures 3, 8 Cyclicargolithus cf. C. neogammation (Bramlette and Wilcoxon). $\times 12,000$. Distal views.

Figures 4,7 Ericsonia obruta Perch-Nielsen. $\times 12,000$. Distal views; some overgrowth in center.

Figure 5 Discoaster barbadiensis Tan Sin Hok. $\times 6000$. Distal view; overgrowth on arms.

Figures 6, 12, Dictyococcotes daviesi (Haq).

$6,13 . \times 6000$. Distal views.

12. $\times 9000$. Proximal views.

Figure 9 Toweius occultatus (Locker). $\times 12,000$. Distal view; selective overgrowth.

Figure $10 \quad$ Reticulofenestra placomorpha (Kamptner). $\times 6000$. Distal view; shields missing?

Figure $11 \quad$ Ericsonia alternans Black. $\times 6000$. Proximal view; some overgrowth. 
PLATE 11

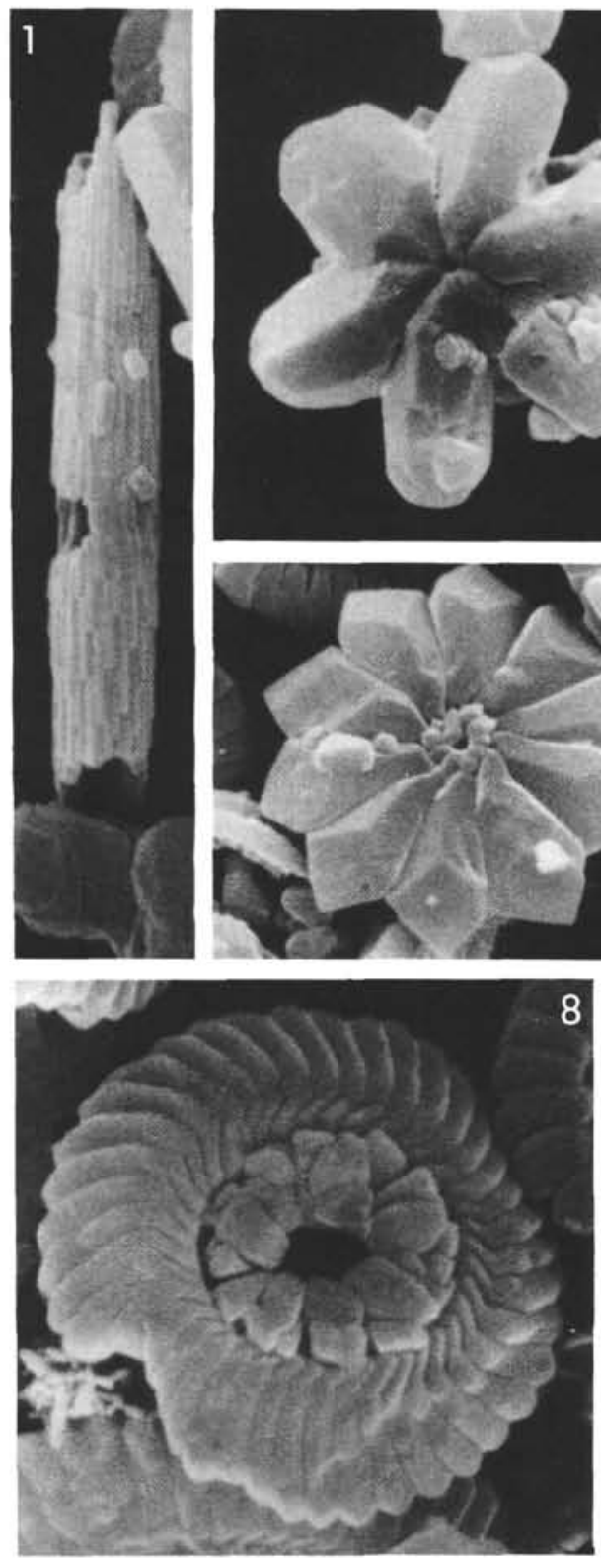

5
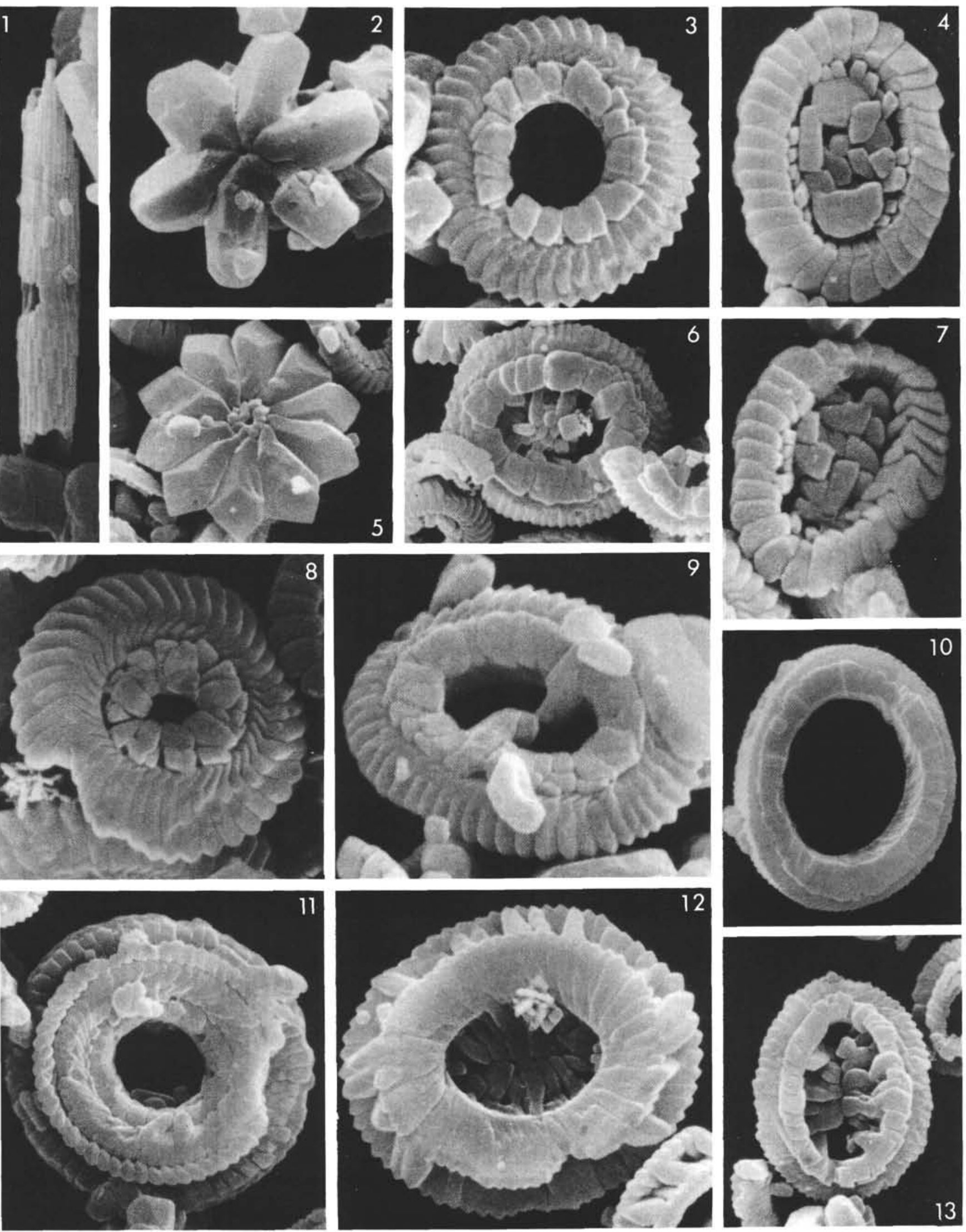
PLATE 12

Calcareous nannofossils.

(Figures 1, 2, 4, 8 from Sample 277-29, CC; Eocene;

Figures 3, 5-7, 9-11 from Sample 277-19; late Eocene to early Oligocene)

Figure 1 Reticulofenestra sp. Small coccosphere; $\times 5700$.

Figures 2, 4, 7 Dictyococcites onustus Perch-Nielsen.

2. $\times 5700$. Distal view.

4. $\times 9000$. Distal view.

7. $\times 11,400$. Distal view.

Figures 3, 6, Dictyococcites ? sp. 1. $\times 11,400$.

$9,113,6$. Proximal views.

9, 11. Distal views.

Figure 5 Dictyococcites callidus Perch-Nielsen. $\times 5700$. Distal view; etching and overgrowth.

Figures 8, 10 Cribrocentrum coenurym (Reinhardt). $\times 11,400$. Proximal views; etching and overgrowth. 
PLATE 12
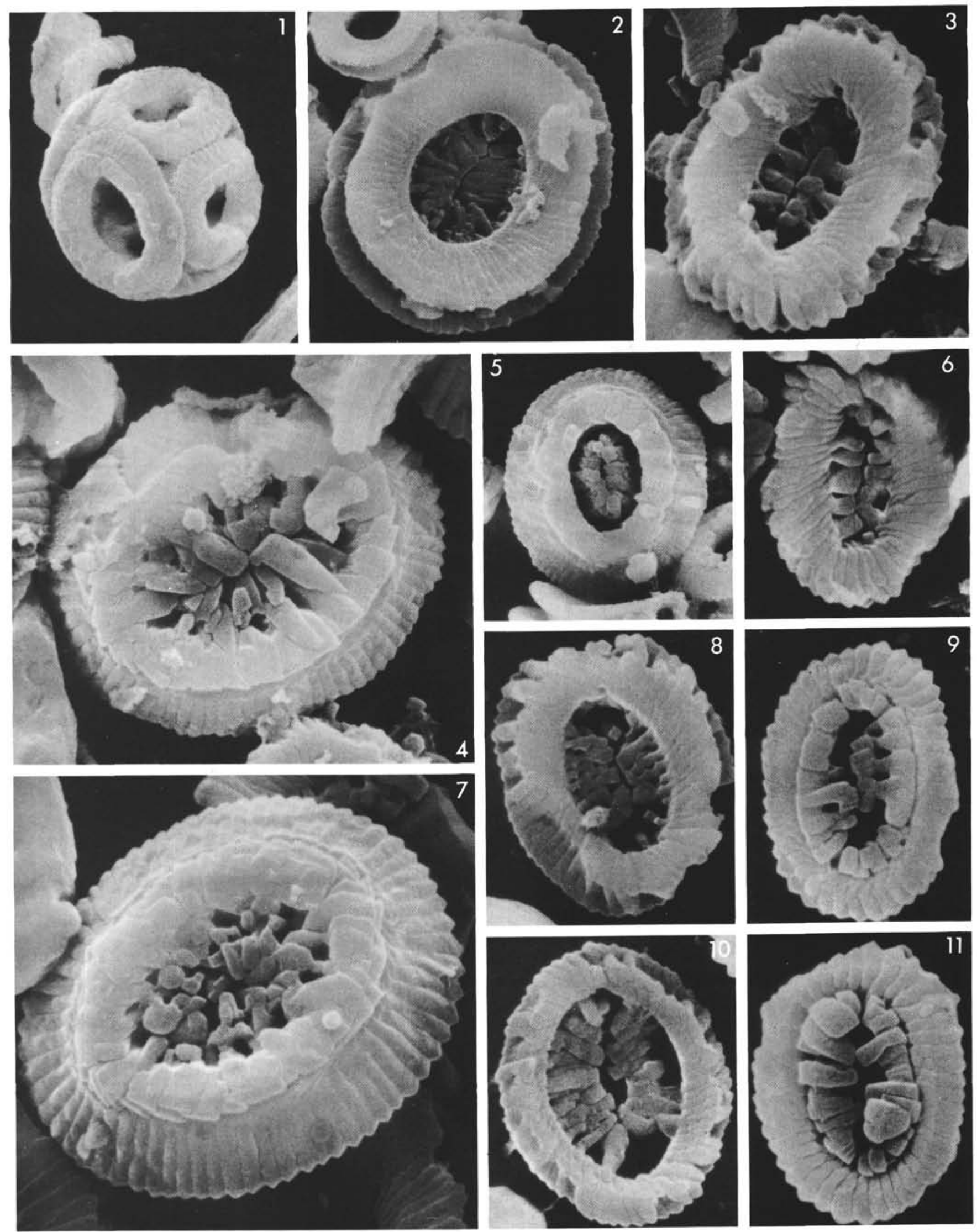
PLATE 13

Calcareous nannofossils.

(Figures 1-3, 5, 7, 10, 11 from Sample 277-29, CC; Eocene:

Figures 4, 6, 8, 9, 12 from Sample 277-19, CC; late Eocene to early Oligocene)

Figures 1, 2 Rhabdolith stems with heavy overgrowth of selected elements while others are well preserved. Overgrowth results in forms similar to the Late Cretaceous Microrhabdulus belgicus; $\times 5700$.

Figures 3, 4 Ericsonia obruta Perch-Nielsen. Proximal views of specimens without proximal shields; $\times 11,400$.

Figure $5 \quad$ Neococcolithes dubius (Deflan-dre). $\times 9000$. Minor overgrowth of central structure.

Figure 6 Transversopontis prava Locker. $\times 5700$. Distal view; etching and overgrowth.

Figure $7 \quad$ Chiasmolithus expansus (Bramlette and Sullivan). $\times 5700$. Distal view; diffuse etching and overgrowth.

Figure $8 \quad$ Chiasmolithus cf. C. oamaruensis (Deflandre). $\times 5700$. Distal view; diffuse overgrowth in wall.

Figures 9, 12 Isthmolithus recurvus Deflandre. $\times 9000$. Heavy overgrowth.

Figure $10 \quad$ Ericsonia ovalis Black. $\times 11,400$. Distal view; selective overgrowth.

Figure $11 \quad$ Markalius? sp. 2. $\times 11,400$. Proximal view; heavy overgrowth. 
PLATE 13
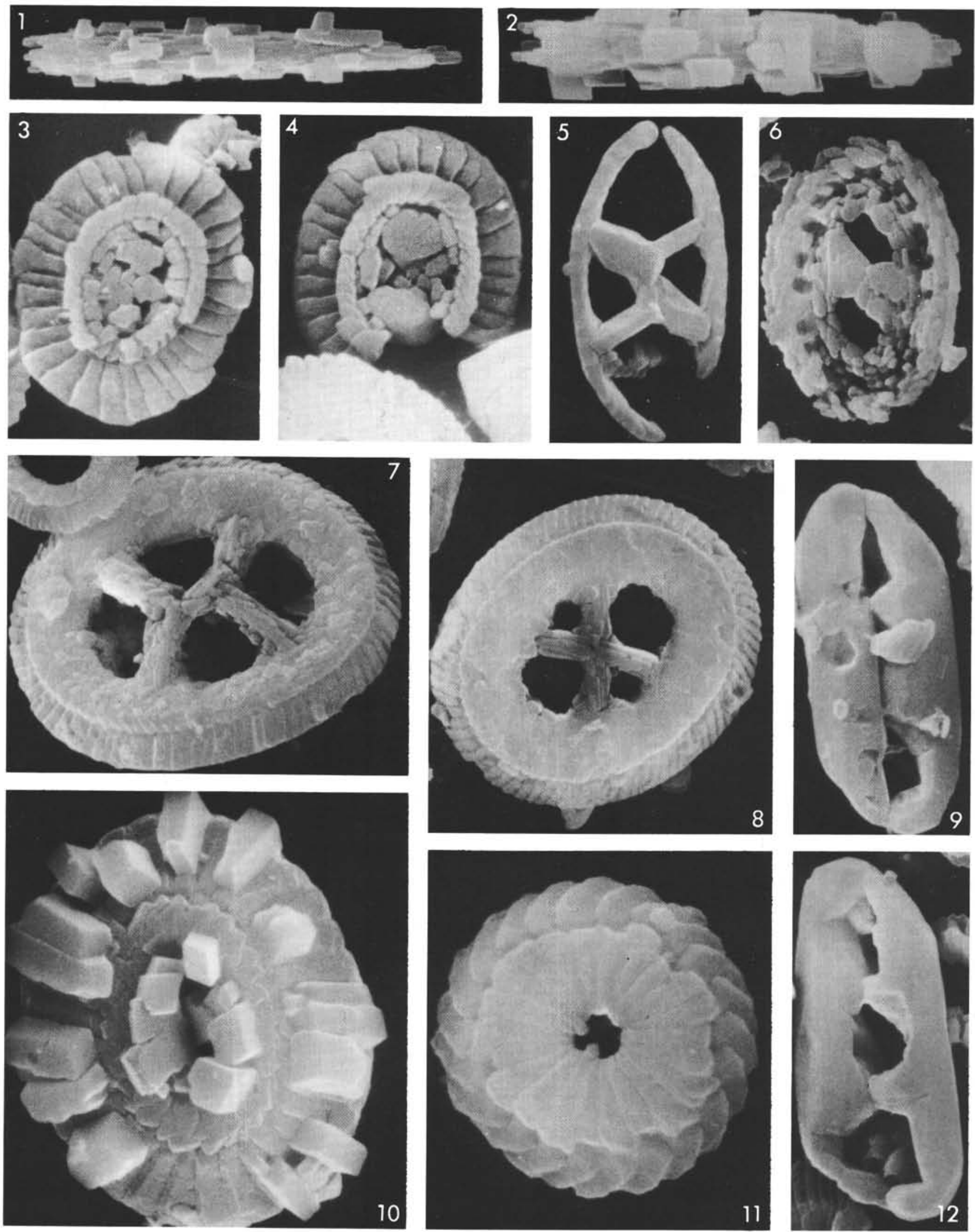
A. R. EDWARDS, K. PERCH-NIELSEN

PLATE 14

Calcareous nannofossils from Sample 277-16-5, $110 \mathrm{~cm}$; early Oligocene

Figures 1-7 Helicopontosphaera ? subantarctica $\mathrm{n}$. sp.

$1-5,7 . \times 6100$. Distal views.

6 . $\times 12,200$. Proximal views. 
PLATE 14
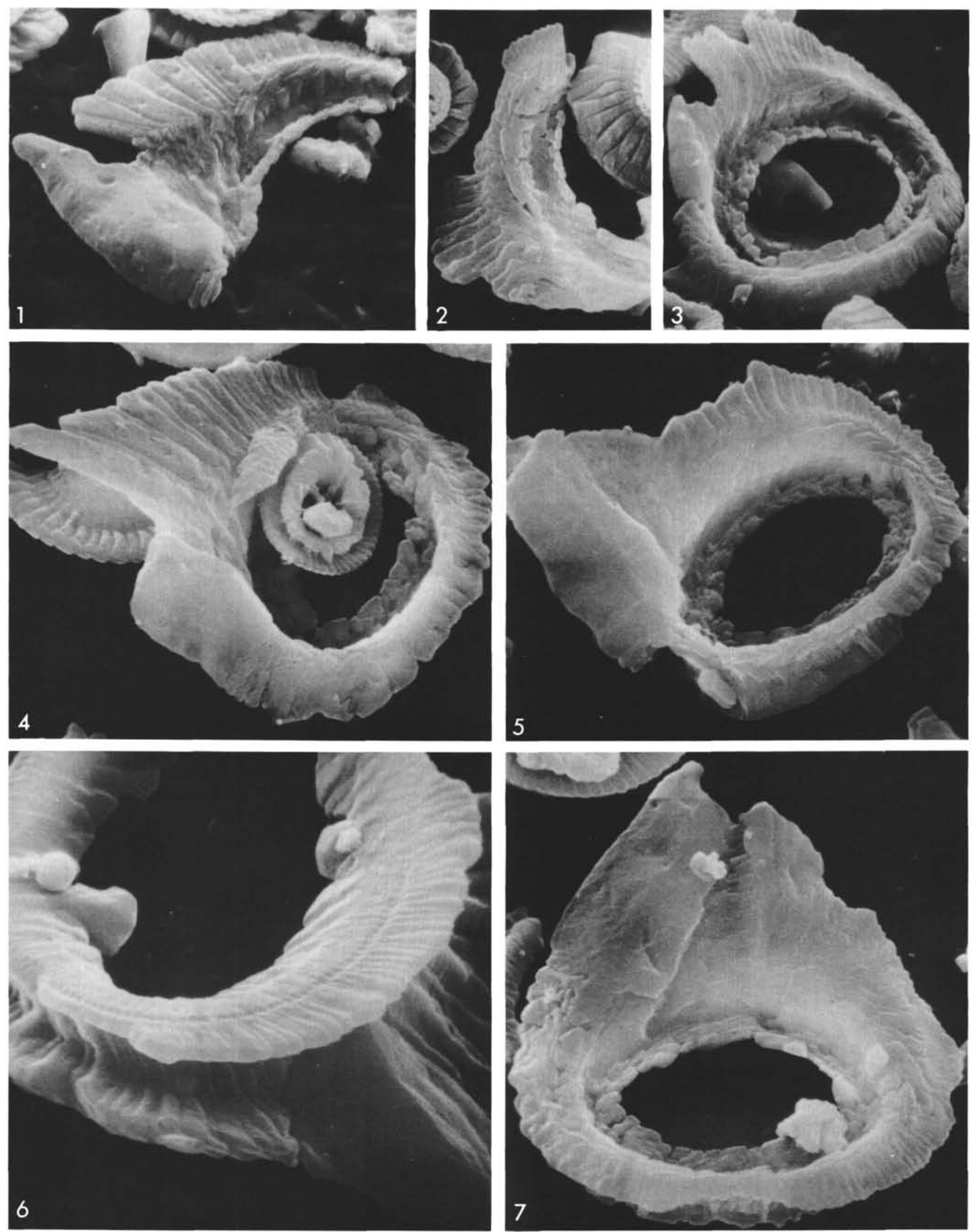
PLATE 15

Oligocene calcareous nannofossils.

Figures 1-3, Helicopontosphaera? subantarctica n. sp. Sample 7,8 277-16-5, $110 \mathrm{~cm}$; early Oligocene; $\times 6000$.

3, 8. Holotype. Distal views.

7. Proximal view.

Figures 4, 5, Chiasmolithus altus Bukry and Percival. 9,10 4. Sample 277-3-3, $110 \mathrm{~cm}$; mid-late Oligocene; $\times 5700$. Distal view.

5. Sample $277-6-4,110 \mathrm{~cm}$; mid-late Oligocene; $\times 5700$. Distal view.

9. Sample $277-16-5,110 \mathrm{~cm}$; early Oligocene; $\times 6000$. Distal view.

10. Sample $277-13-2,110 \mathrm{~cm}$; mid-late Oligocene; $\times 5700$. Distal view.

Figure 6 Isthmolithus recurvus Deflandre. Sample 277-16-5, $110 \mathrm{~cm}$; early Oligocene; $\times 9000$.

Figure 11 Syracosphaera? sp. Sample 277-16-5, $110 \mathrm{~cm}$; early Oligocene; $\times 11,800$. Distal view. 


\section{PLATE 15}
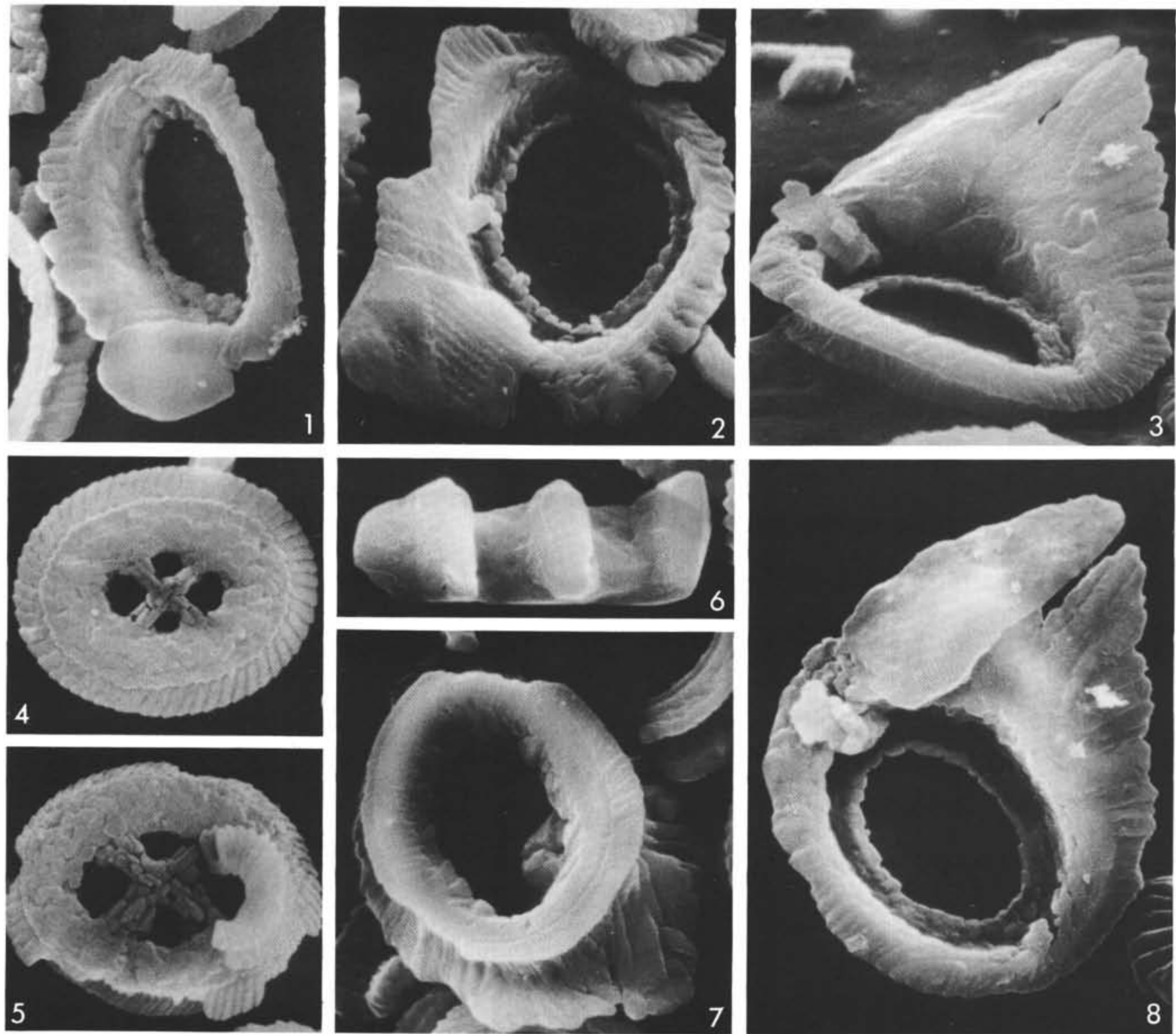

5
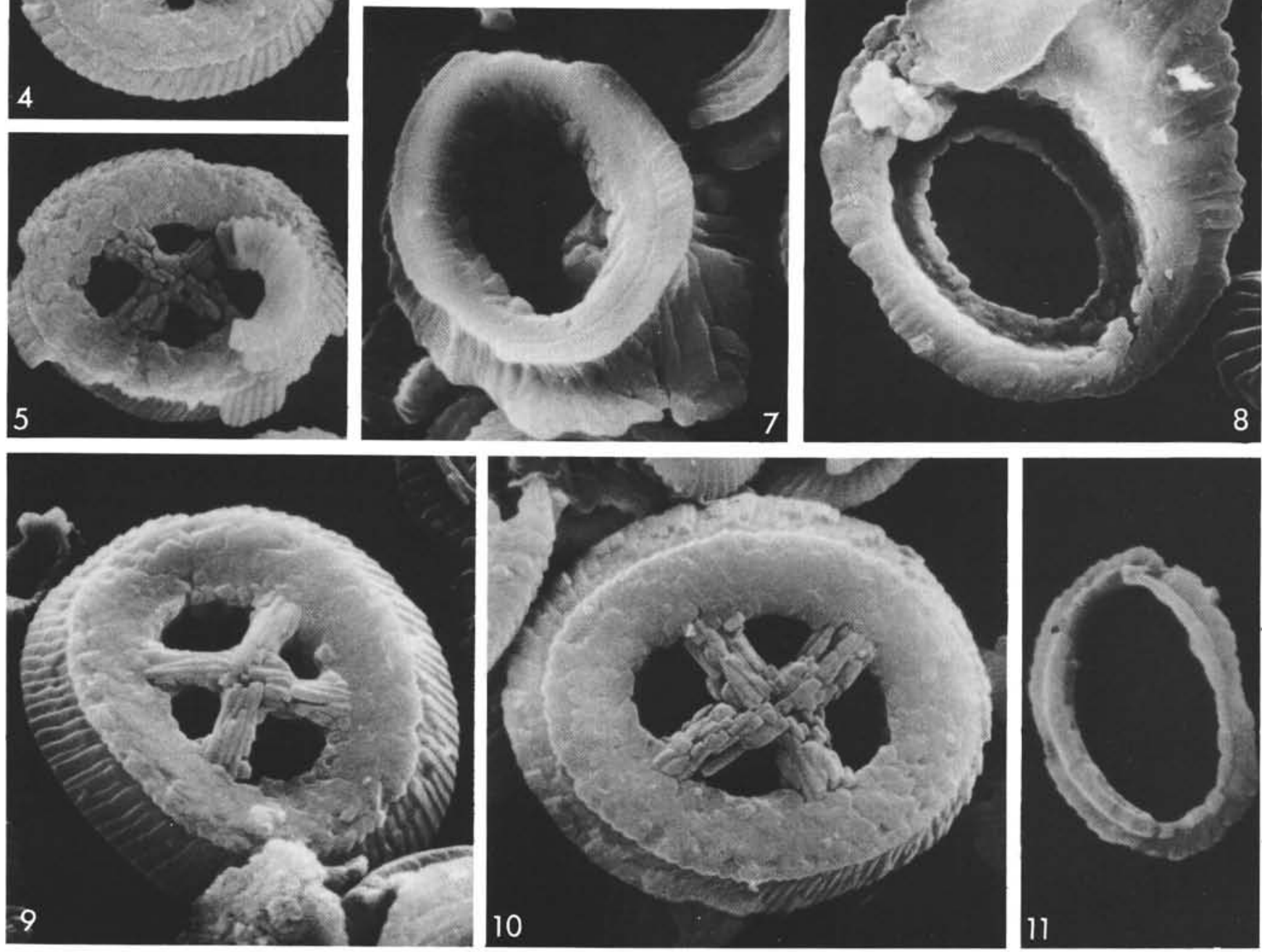


\section{PLATE 16}

Calcareous nannofossils.

(Figures 6, 7, 14 from Sample 277-16-5, $110 \mathrm{~cm}$; early Oligocene. Figures 11, 13 from Sample 277-13-3, $110 \mathrm{~cm}$; mid-late Oligocene. Figures 3, 5, 9, 10, 16 from Sample 277-6-4, $110 \mathrm{~cm}$; mid to late Oligocene. Figures 1, 2, 4, 8, 12, 15 DSDP $277-3-3,110 \mathrm{~cm}$; mid to late Oligocene.)

Figure 1 Discoaster deflandrei ? Bramlette and Riedel. $\times 5800$. Heavy overgrowth.

Figures 2-7, $\quad$ "Reticulofenestra" cf. $R$. alabamensis Roth.

$11,12 \quad 2-5,11,12 . \times 5800$.

6, 7. $\times 5900$.

Figure 8 Discolithina segmenta Bukry and Percival. $\times 11,600$. Distal view; etching and overgrowth.

Figures 9, 10 Reticulofenestra $\mathrm{cf}$. $R$. pseudoumbilica (Gartner). $\times 5800$. Proximal and distal views.

Figure 13 Cyclicargolithus neogammation (Bramlette and Wilcoxon). $\times 5700$. Proximal view, small specimen.

Figures 14, 15 "Reticulofenestra" bisecta (Hay et al.)

14. $\times 6000$. Distal view.

15. $\times 5800$. Proximal view.

Figure 16 "Reticulofenestra" abisecta (Müller). $\times 5800$. Distal view. 
PLATE 16
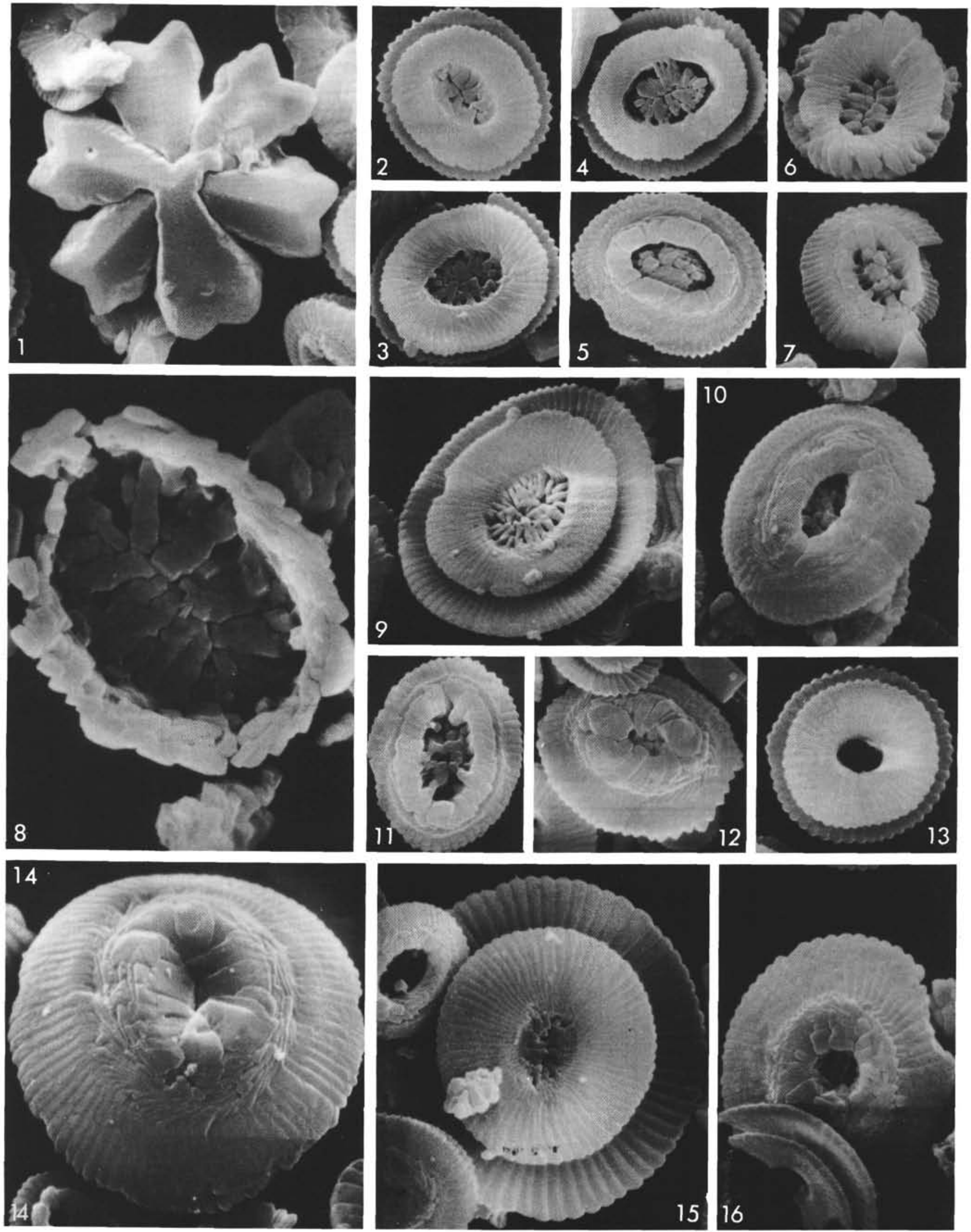


\section{PLATE 17}

Calcareous nannofossils from Sample 279A-5-4, $110 \mathrm{~cm}$; early Miocene.

Figures 1, 3, 4 Reticulofenestra sp. $\times 5700$. Proximal and distal views; overgrowth in walls.

Figure 2 Cyclicargolithus neogammation (Bramlette and Wilcoxon). $\times 4500$. Proximal view.

Figure $5 \quad$ Cyclococcolithus macintyrei Bramlette and Bukry. $\times 2900$. Distal view; slight etching and overgrowth.

Figure 6 Discoaster adamanteus Bramlette and Wilcoxon. $\times 5700$. Some overgrowth.

Figures 7, 8 Discoaster deflandrei Bramlette and Riedel. $\times 5700$. Distal views; overgrowth.

Figures 9, 10 Helicopontosphaera granulata Bukry and Percival. $\times 5700$. Distal and proximal views.

Figure 11 Helicopontosphaera sellii Bukry and Bramlette. $\times 5700$. Distal view.

Figures 12-14, Sphenolithus heteromorphus Deflandre. $\times 11,400$. $17,18 \quad$ Variable overgrowth.

Figures 15, 16 Sphenolithus cf. S. moriformis (Brönnimann and Stradner). $\times 11,400$. Etching? 


\section{PLATE 17}
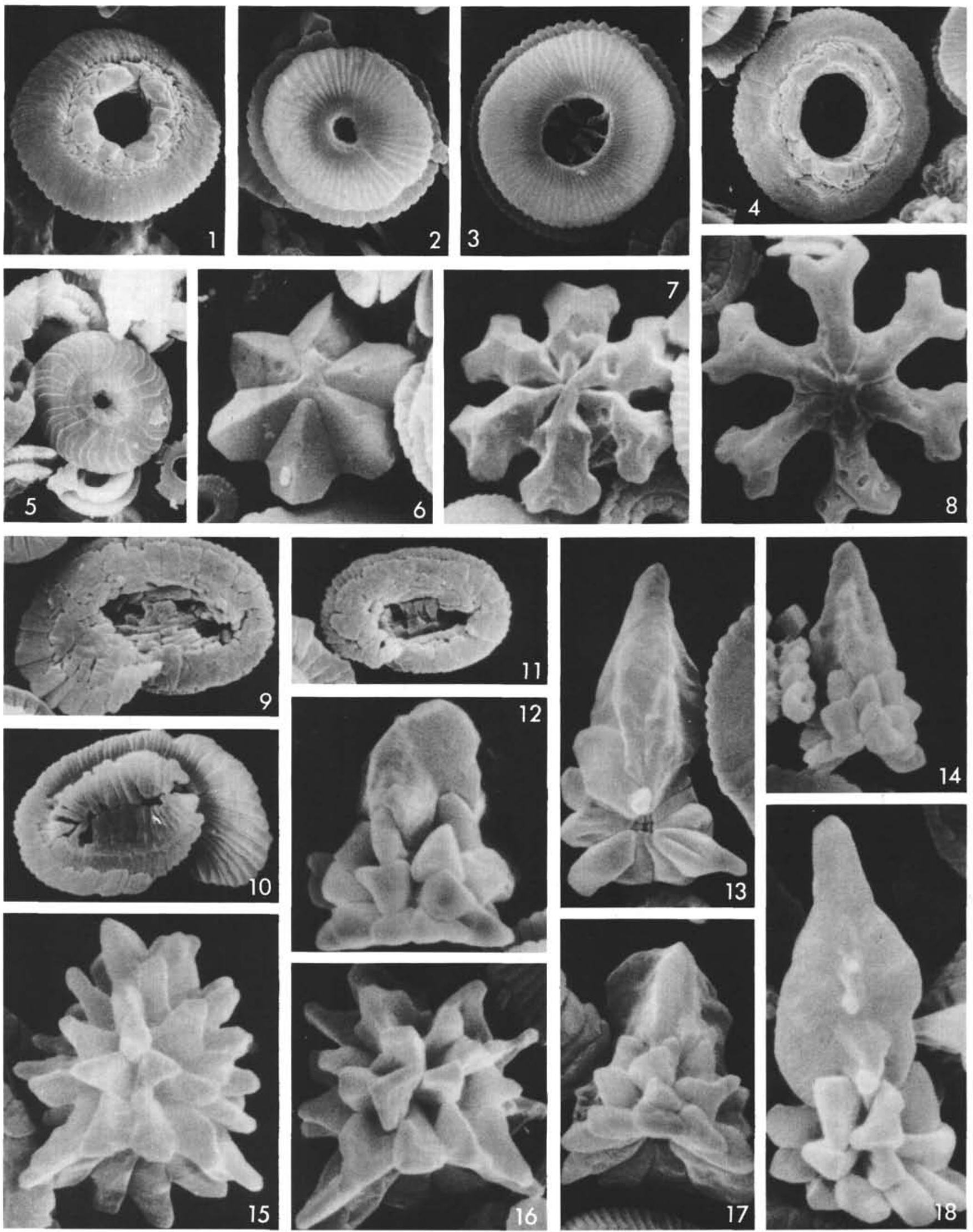


\section{PLATE 18}

Calcareous nannofossils from Sample 279A-5-2, $141 \mathrm{~cm}$; early Miocene.

Figures 1-5 Sphenolithus heteromorphus Deflandre. 1-4. $\times 11,400$. Side views; some overgrowth. 5. Could be mistaken as an overgrown specimen of Triquetrorhabdulus rugosus Bramlette and Wilcoxon. $\times 5700$.

Figure 6 Sphenolithus moriformis (Brönnimann and Stradner). $\times 11,400$. Side view.

Figures 7, 8 Discoaster deflandrei Bramlette and Riedel. $\times 5700$. Etching and overgrowth.

Figure 8 Ericsonia ovalis Black. $\times 5700$. Distal view; selective heavy overgrowth.

Figure 9 Helicopontosphaera intermedia (Martini). $\times 5700$ Proximal view; some etching.

Figures 10-12 Helicopontosphaera granulata Bukry and Bramlette. $\times 5700$. Distal and proximal views.

Figure 13 Chiasmolithus altus Bukry and Percival. $\times 5800$ (Reworked?) Distal view.

Figure 14 (?)Cyclococcolithus sp. 1. $\times 11,400$. Proximal view of distal shield?

Figure 15 Helicopontosphaera euphratis $(\mathrm{Haq}) . \times 5700$. Proximal view; damaged and etched specimen. 
PLATE 18
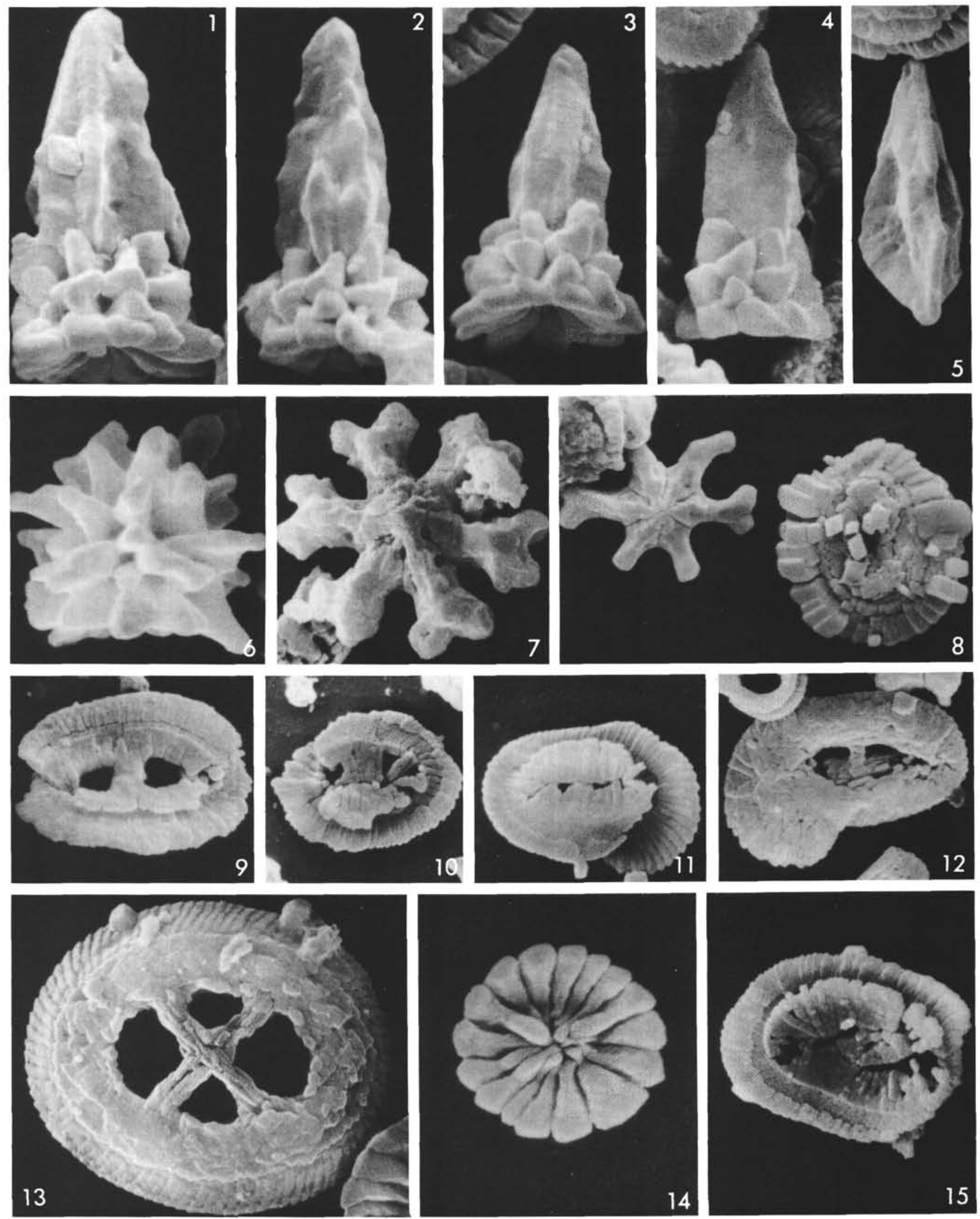


\section{PLATE 19}

Calcareous nannofossils from Sample 282-5-1, $136 \mathrm{~cm}$; early Miocene.

Figures 1, 6-10 Sphenolithus cf. $S$. conicus Bukry. $\times 11,600$.

Figure 2 Coronocyclus nitescens $($ Kamptner). $\times 5800$. Distal view; selective overgrowth.

Figure 3 Discoaster $\mathrm{cf}$. D. saundersi Hay. $\times 5800$. Proximal view; etching and overgrowth.

Figure $4 \quad$ Pontosphaera cf. P. multipora $($ Kamptner). $\times 5800$. Proximal view; slight etching.

Figure $5 \quad$ ?Sphenolithus sp. 4. $\times 11,600$.

Figure 11 Sphenolithus moriformis (Brönnimann and Stradner). $\times 11,600$. Etching. 
PLATE 19
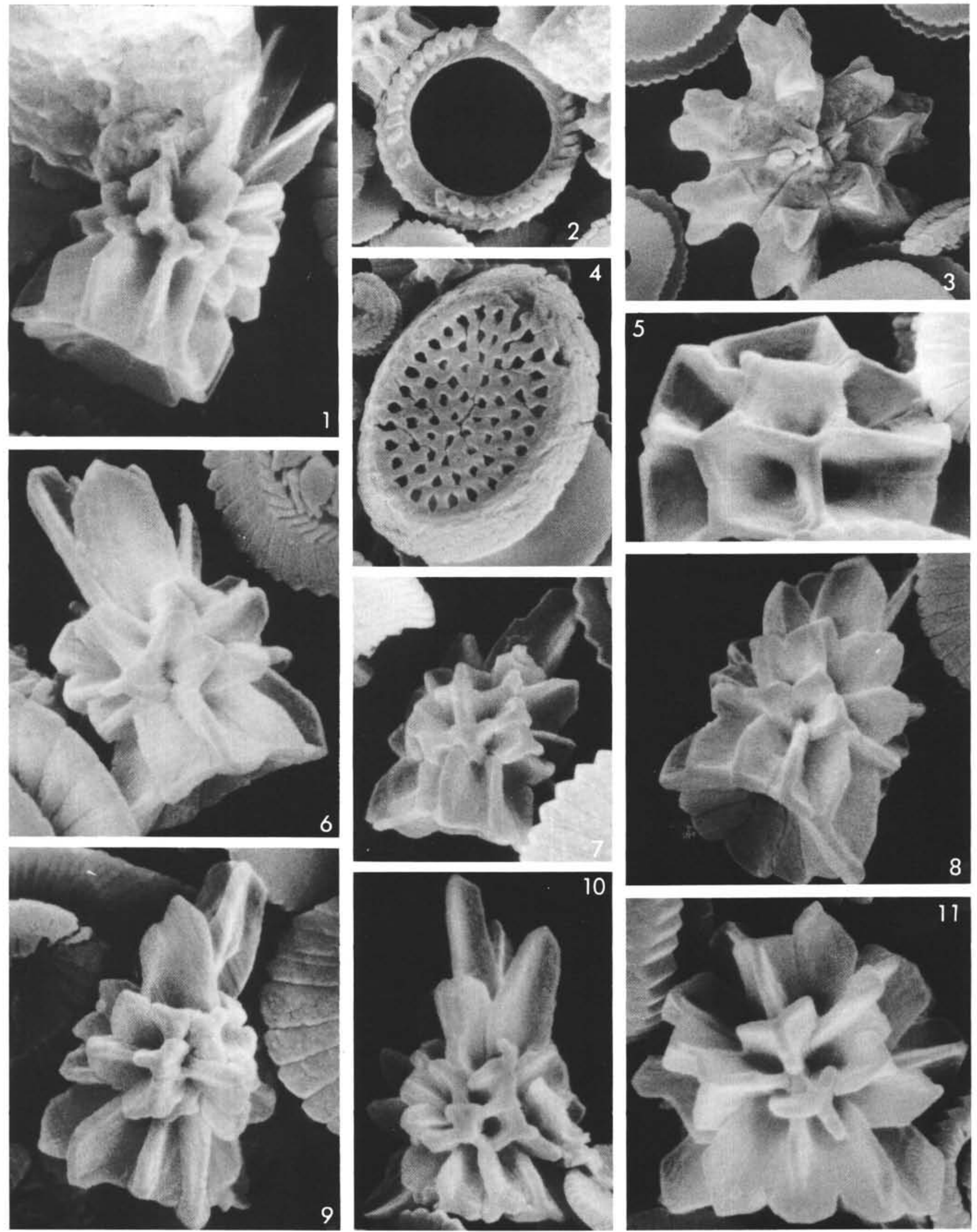
PLATE 20

Calcareous nannofossils.

(Figures 3, 5, 9-11, Sample 282-4-1, $110 \mathrm{~cm}$; early Miocene,

Figures 1, 2, 4, 6-8, 12, Sample 282-4, CC; early Miocene)

Figure $1 \quad$ Sphenolithus abies Deflandre. $\times 12,100$. Side view.

Figure 2 Sphenolithus moriformis group (Brönnimann and Stradner). $\times 12,000$. Side view.

Figure 3 Ilselithina sp. 1. $\times 12,000$. Youngest known to date of this late Paleogene genus. Side view; damaged specimen.

Figure 4 Coronocyclus nitescens $($ Kamptner). $\times 9600$. Distal view.

Figures 5-12 Ericsonia tasmaniae n. sp. $\times 12,000$.

5. Holotype.

5-8. Distal views.

11. Paratype.

9-12. Proximal views. 


\section{PLATE 20}
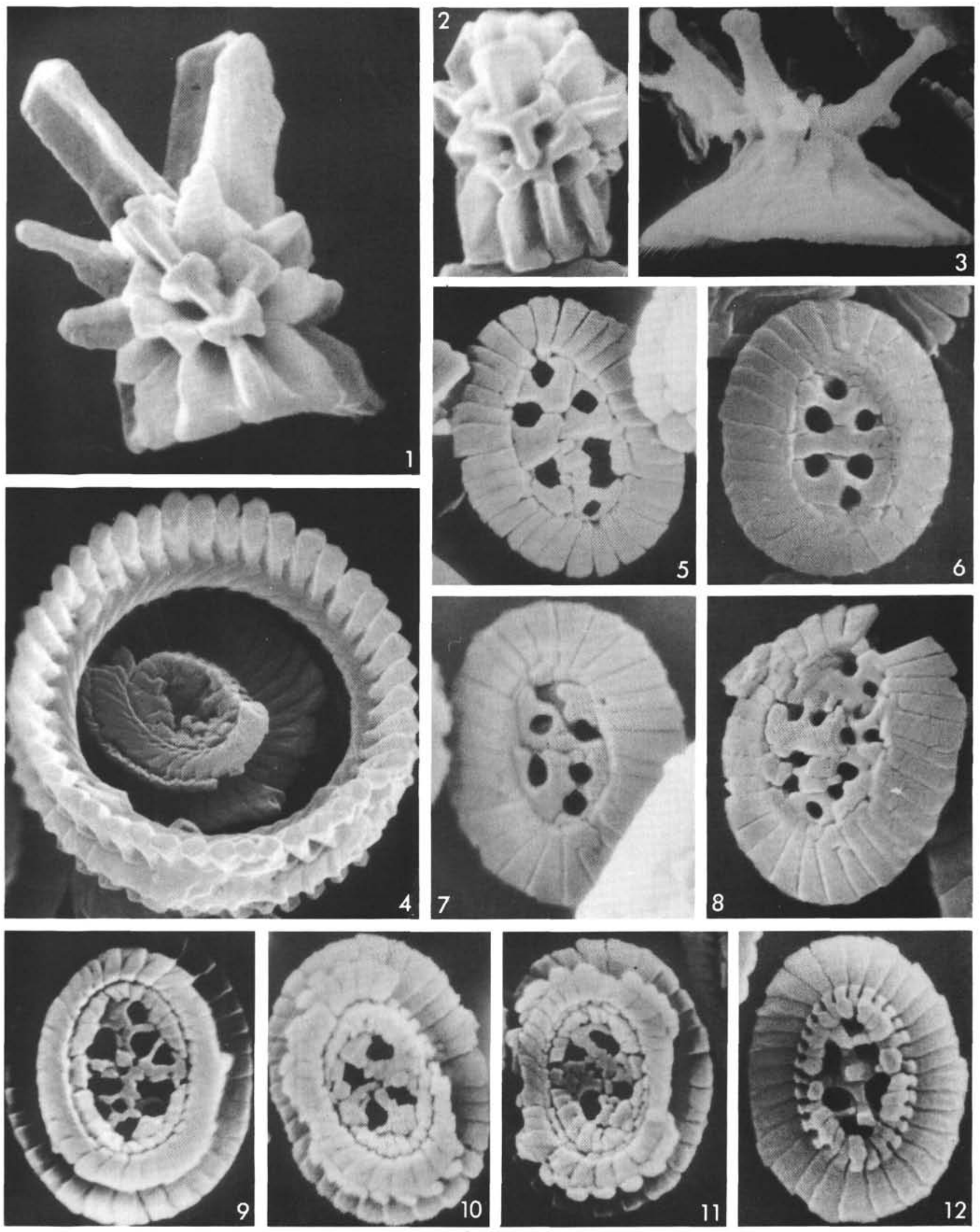


\section{PLATE 21}

Neogene calcareous nannofossils at Site 284.

$$
\text { (All figures } \times 2000 \text { ) }
$$

Figures 1-6 Ericsonia tasmaniae n. sp. Sample 282-4-1, $110 \mathrm{~cm}$; early Miocene.

Figures 7-14 Hornibrookina australis n. sp.

7-10. Sample 277-45-2, $118 \mathrm{~cm}$; late Paleocene.

11, 12. Sample 277-46-4, $111 \mathrm{~cm}$; late Paleocene.

13, 14. Sample 277-45-3, $127 \mathrm{~cm}$; late Paleocene.

Figure 15 Holococcolith. Sample 284-10-5, $110 \mathrm{~cm}$; early Miocene.

Figure $16 \quad$ Ilselithinia sp. Sample 282-4-1, $110 \mathrm{~cm}$; early Miocene.

Figures 17-20 Helicopontosphaera? subantarctica n. sp. Sample 277-16-5, $110 \mathrm{~cm}$; early Oligocene.

Figure 21 Ceratolithus rugosus Bukry and Bramlette. Sample 284-10-5, 110 $\mathrm{cm}$; early Pliocene.

Figures 22-48 Ceratolithus triconiculatus group Gartner. No birefringence shown.

22. Sample 284-10-2, $135 \mathrm{~cm}$; early Pliocene.

23. Sample $284-10-5,110 \mathrm{~cm}$; early Pliocene.

24. Sample 284-10, CC; early Pliocene.

25. Sample 284-12-1, $110 \mathrm{~cm}$; early Pliocene.

26. Sample $284-11-4,110 \mathrm{~cm}$; early Pliocene.

27 , 29. Sample $284-13-4,110 \mathrm{~cm}$; early Pliocene.

$28,30,32$. Sample 284-14-4, $110 \mathrm{~cm}$; early Pliocene.

31. Sample 284-14-1, $110 \mathrm{~cm}$; early Pliocene.

33, 34. Sample 284-16-3, $110 \mathrm{~cm}$; late Miocene.

35, 36. Sample 284-17-4, $110 \mathrm{~cm}$; late Miocene.

37, 38. Sample 284-18-6, $110 \mathrm{~cm}$; late Miocene.

39, 41. Sample 284-19-2, $110 \mathrm{~cm}$; late Miocene.

40, 42. Sample 284-19-3, $110 \mathrm{~cm}$; late Miocene.

43. Sample 284-19-1, $140 \mathrm{~cm}$; late Miocene.

44. Sample 284-29-4, $110 \mathrm{~cm}$; late Miocene.

45-47. Sample 284-22-2, $110 \mathrm{~cm}$; late Miocene.

48. Sample 284-22-4, $110 \mathrm{~cm}$; late Miocene.

Figures 49, 50 Ceratolithus primus Bukry and Percival.

49. Sample 284-22-1, $135 \mathrm{~cm}$; late Miocene.

50. Sample 284-22-6, $110 \mathrm{~cm}$; late Miocene; slight birefringence. 
PLATE 21
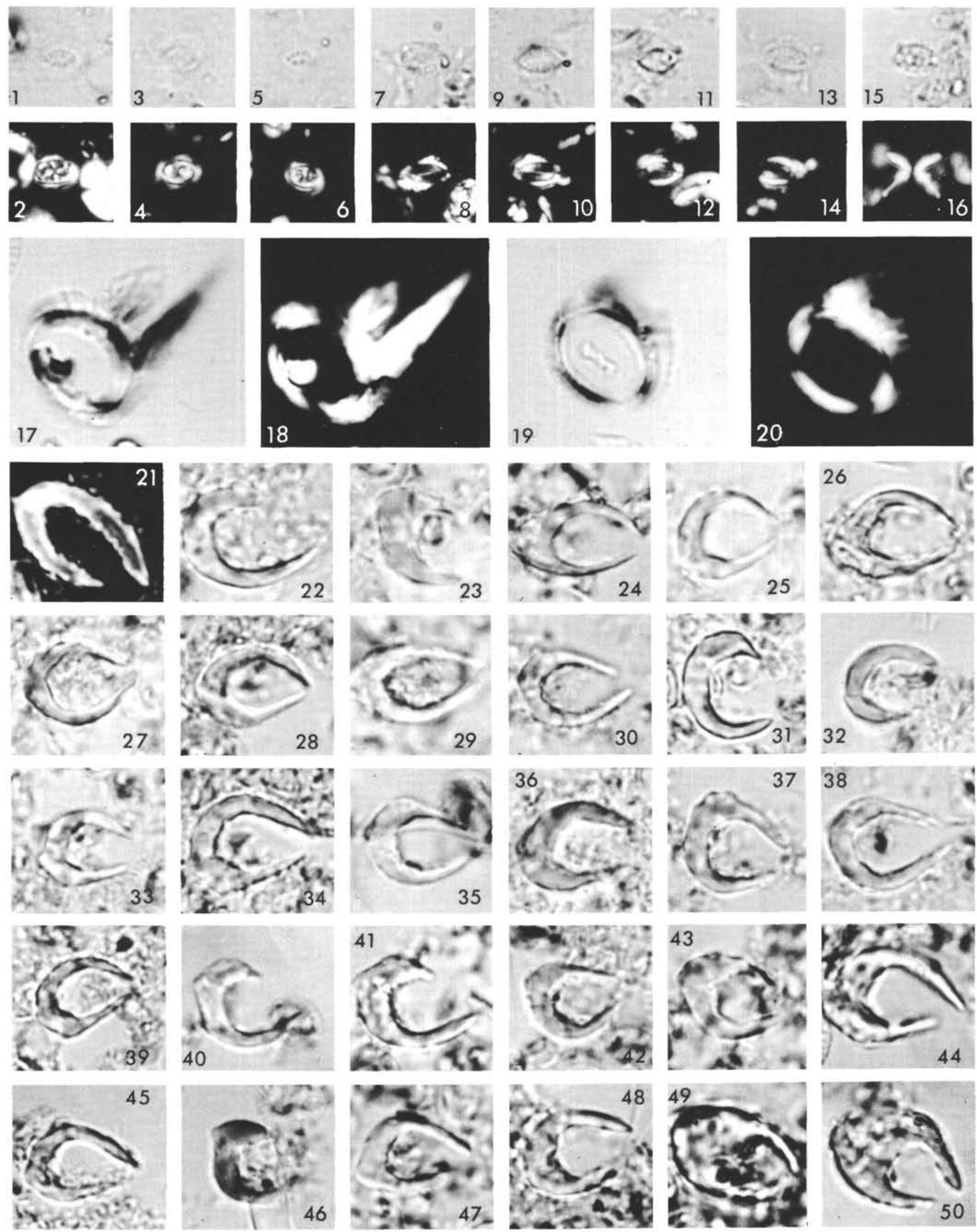

bxirksta:?
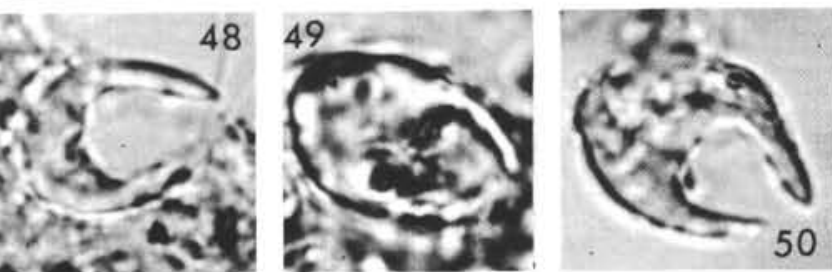